
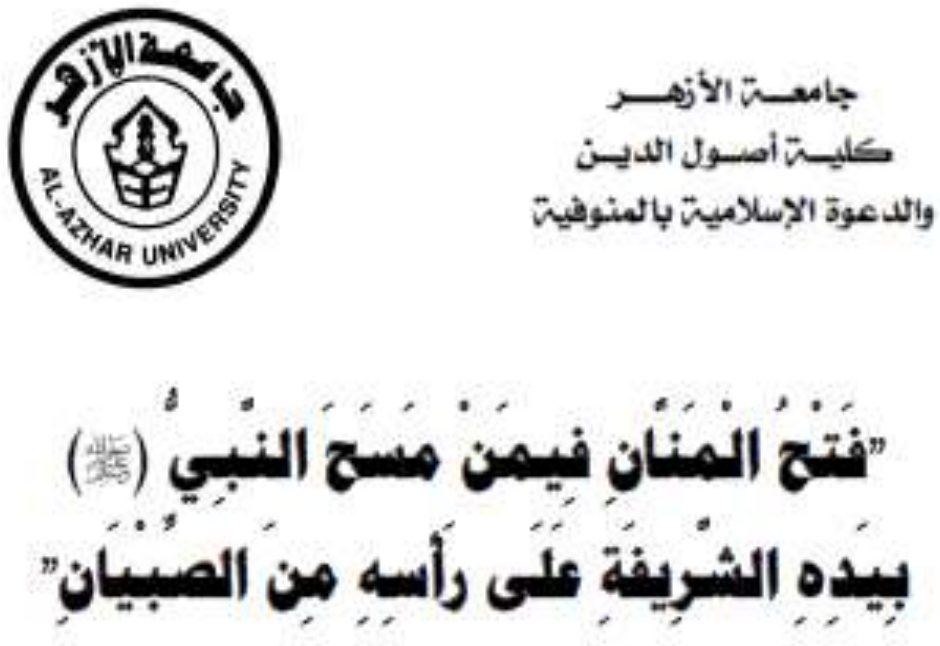

\title{
إعراز الركتور
}

حدي عبد العظيم فرحات إبراهيم

أستاذ مساعل - قسهم الحلفيث وعلومها

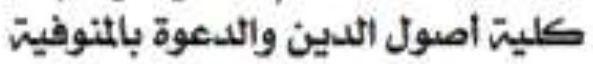

as b̈lino

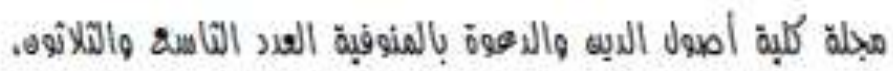

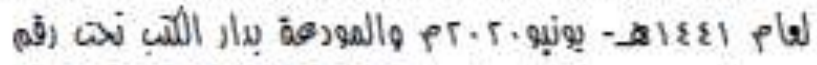

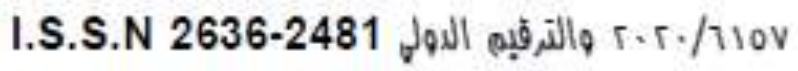





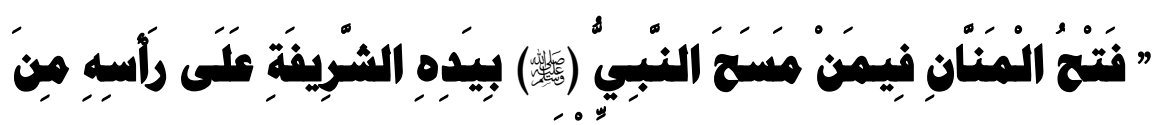 \\ |"لمبنان}

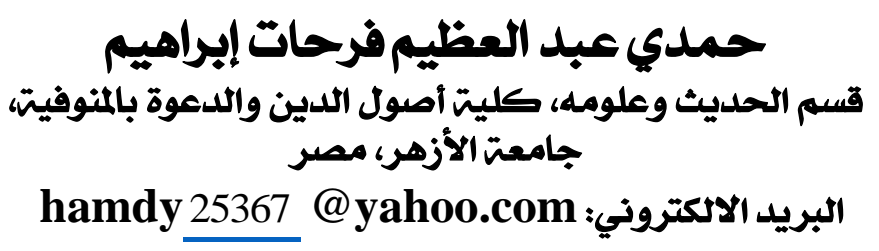

|ملفخص:

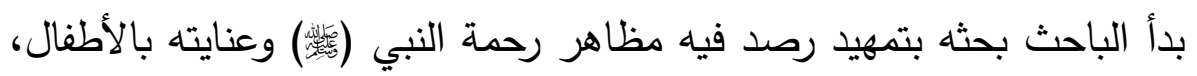
حيث كان (敞) يكثر السلام عليهج، ويجالسهم، ويداعبهم، ويمسح على رؤوسهم، وغير ذلك، ثم تحدث الباحث في المبحث الأول عن مظهر من هذه المظاهر ونه وبرة فذكر من مسح النبي (赔) على رأسه من الصبيان، وترجم لهم الباحث مرتبًا أسماءهم على حروف المعجم، ثم تتاول الباحث في المبحث الثاني الأثر الحسي

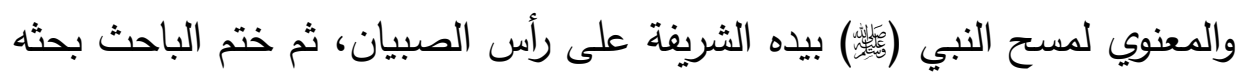
بخاتمة اشتملت على ما توصل إليه في هذا البحث من نتائج وتوصيات.

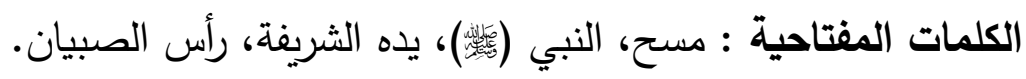

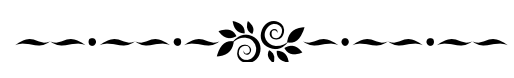




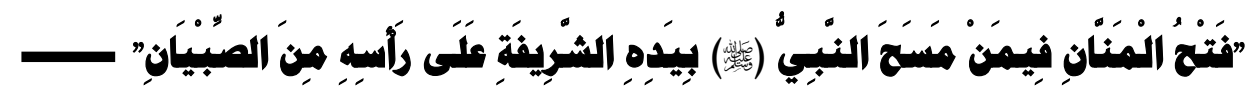

\title{
"Fath Al-Mannan, those whom the Prophet Wiped with his Honorable hand over his Head from the Youngsters"
}

\author{
Hamdy Abdelazim Farahat Ibrahim. \\ Department of Hadith and its studies, Faculty of \\ fundamentals of Religion \& mission, in menoufiyya. \\ Alazhar University, Egypt. \\ Email: hamdy 25367 @yahoo.com
}

\section{Abstract:}

The research begins by monitoring the manifestations of the Prophet's mercy and caring for children; He used to frequent salute, sit with them, tickles with them, wipes their heads, and so on.

The researcher talked in his first topic about one of these manifestations with representing to whom the Prophet wiped on his head of the youngsters, arranging their names according to the letters of the dictionary. He then talked in his second topic about the tangible and spiritual impact of the prophet's wiping with his honorable hand on the head of the children. And for the conclusion, It included the results and recommendations came up with this research.

Keywords: Wiping, The Prophet, His honorable hand, Head of youngsters.

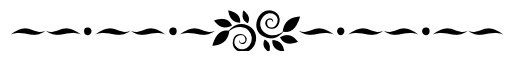




\section{مجللح كلية اصول الدين والدعوة بالموفية العدد التاسع والثلاثون}

\section{ve}

إن الحمد الله نحمده ونستعينه ونستغفره، ونعوذ باله من شرور أنغسنا وسيئات

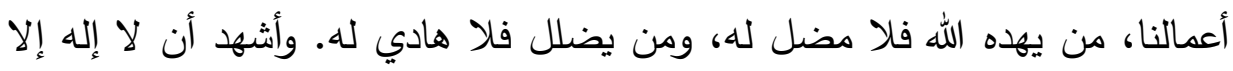
الله، وأشهد أن محمدًا عبده ورسوله.

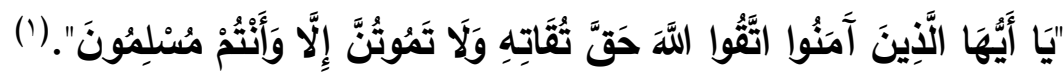

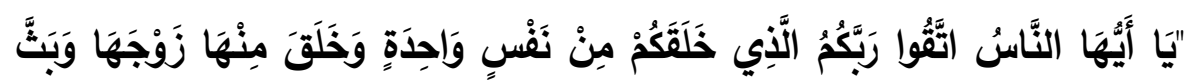

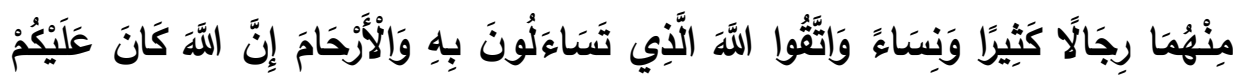

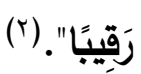

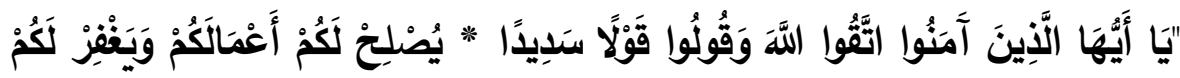

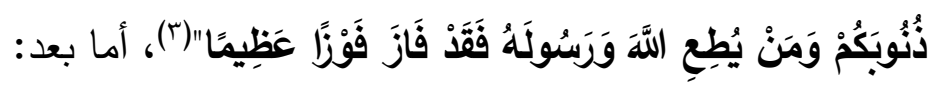

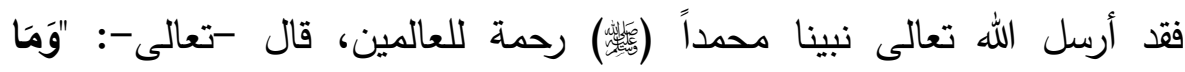

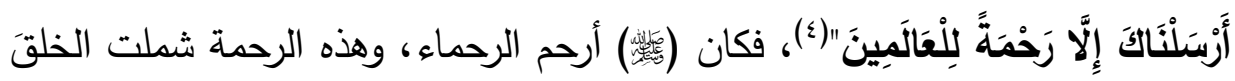

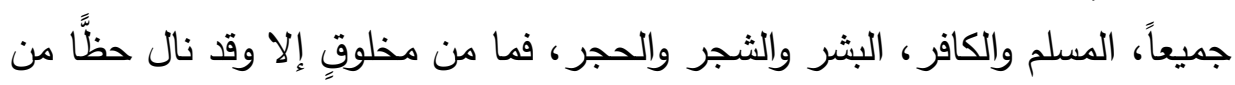

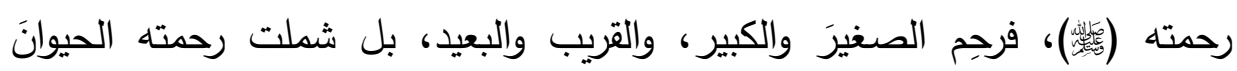
والجماد. كتب السنة برصد واهتمت مظاهر رحمته (赔) وعنايته، وخاصة بالضعفاء من الشيوخ والنساء والأطفال.

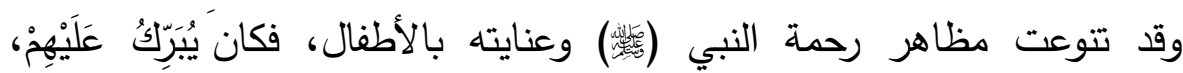
وَيُحَنَكُهُهْ، ويكثر السلام عليهم، ويجالسهم، ويداعبهم، ولا يفرق في ذلك بين الذكر

$$
\begin{aligned}
& \text { (1) آل عمران: r (1) }
\end{aligned}
$$

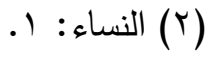

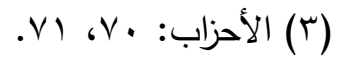

$$
\begin{aligned}
& \text { (ع) الأنبياء: v• }
\end{aligned}
$$




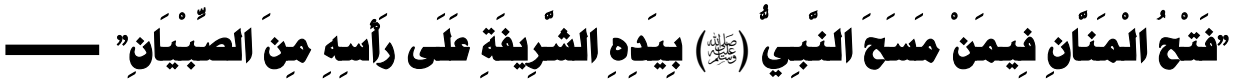

$$
\text { والأنثى. }
$$

بل يعجب الإنسان من مظاهر اعتنائه (ب⿶凵 ) ورحمته بالأطفال إذا نظر إلى كثرة المهام التي أتقلت كاهله (敬) من بناء الدولة وتعليم المسلمين والجهاد والدعوة وغير ذلك مما لا حصر له.

ولا يخفى ما لهذه العناية بهم من آثار معنوية تخبر عن معاني الحب والعطف والرحمة، وهم بأمس الحاجة لهذه المظاهر التي تعطي لهم الأمن والطمأنينة والاستقرار النفسي.

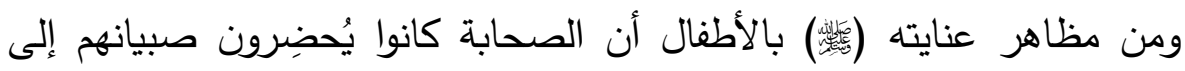

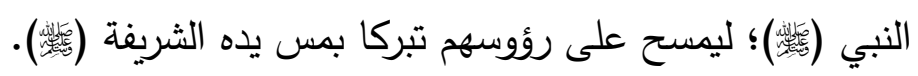

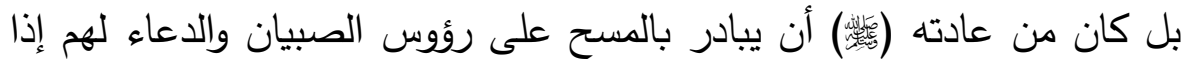

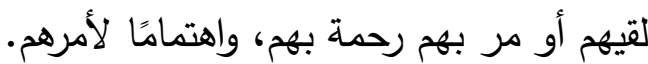
لذا عقد الإمام البخاري في الصحيح بابا بعنوان "باب الدعاء للصبيان بالبركة،

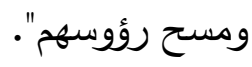

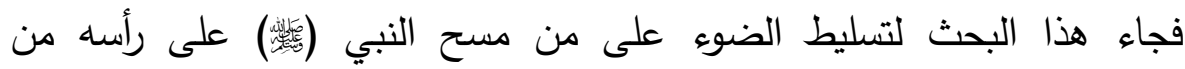
الصبيان، وبيان أثر ذلك عليهم، فجاء بعنوان:

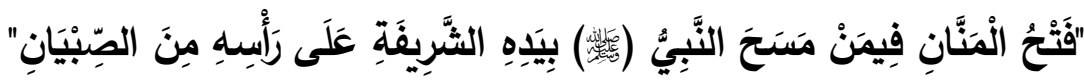

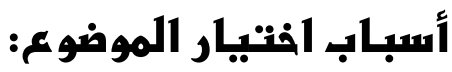

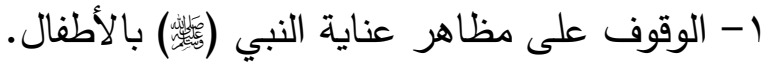

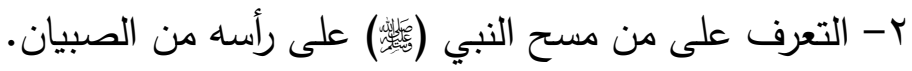

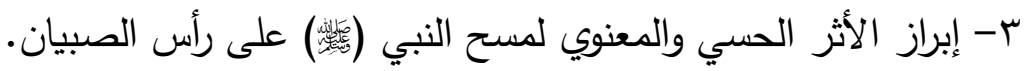

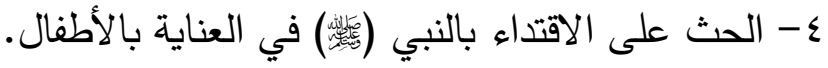
منسمج البهث: اتبعت في هذا البحث المنهج الاستقرائي التحليلي على النحو التالي: 


\section{مجلل كلية اصول الدين والدعوة بالمنوفية العدد التاسع والثلاثثون}

1- استقراء كتب التراجم وكتب الأحاديث المسندة؛ للوقوف على الأحاديث والآثار

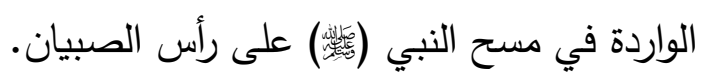

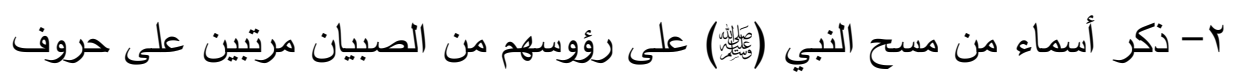

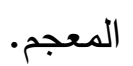

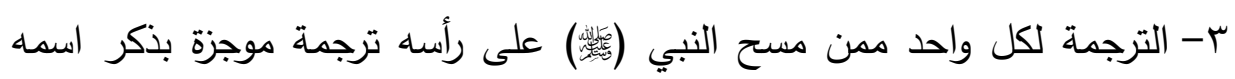
ونسبه وكنيته وسنة وفاته وبعض مناقبه وفق ما ذكر في كتب التراجم.

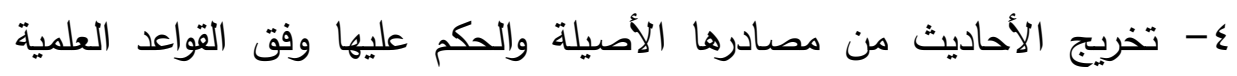
المعتبرة عند المحدثين.

\section{فماة 11}

جاء هذا البحث في مقدمة، وتمهيد، ومبحثين، وخاتمة. أما المقدمة فبينت فيها موضوع البحث، وأسباب اختياره، والمنهج، وخطة البحث.

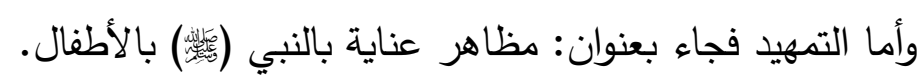

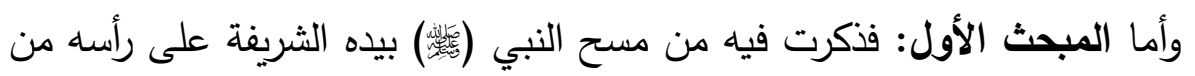
الصبيان مرتبًا أسماءهم على حروف المعجم.

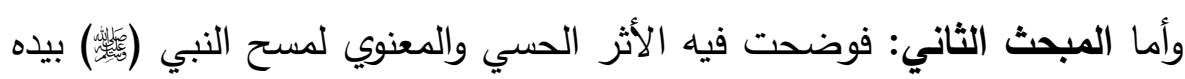
الشريفة على رأس الصبيان، وقد قسمته إلى مطلبين:

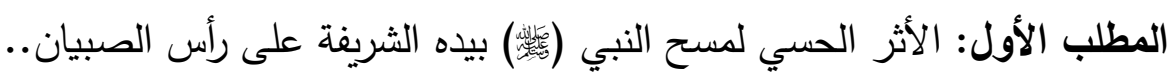

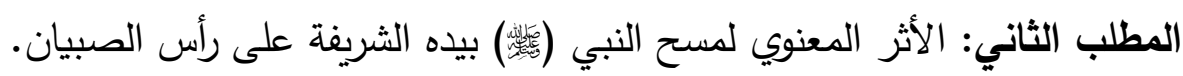
وأما الخاتمة فاشتملت على ما توصلت إليه في هذا البحث من نتائج وتوصيات. ……ำ.ำ........ 


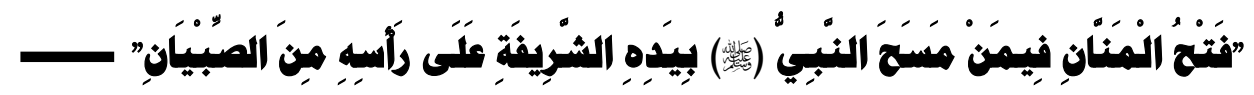

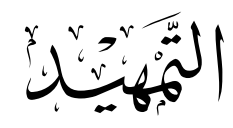

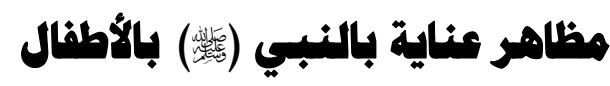

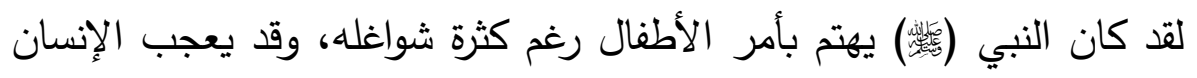

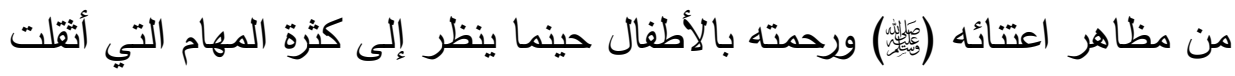

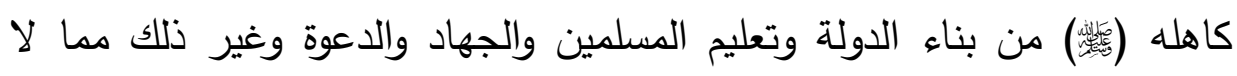

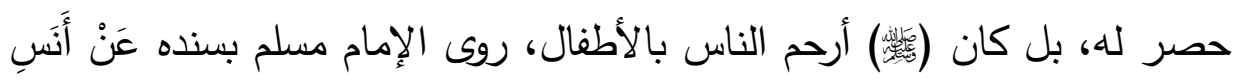

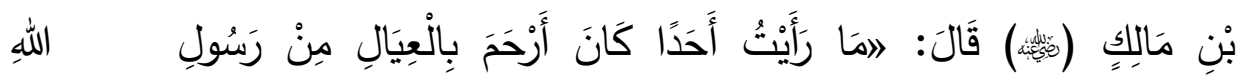
(').《(䔝)

وقد تنوعت مظاهز رحمته وعنايته (苞) بالأطفال في صور عديدة منها:

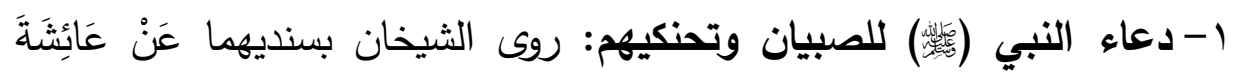

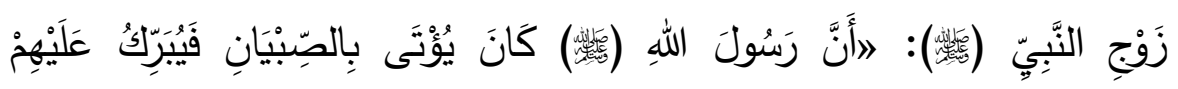

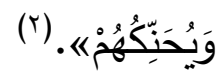

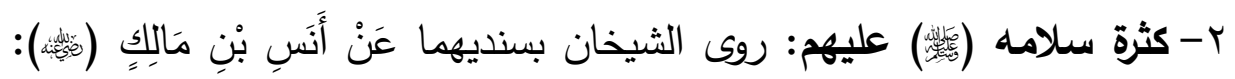

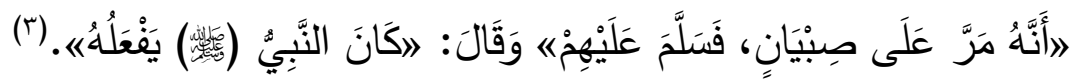

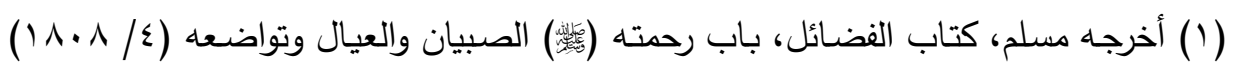

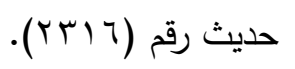

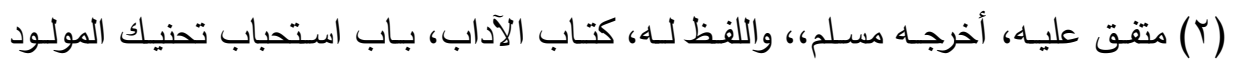

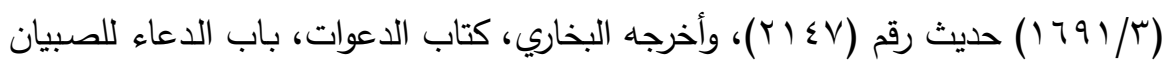

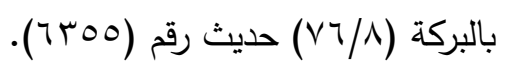

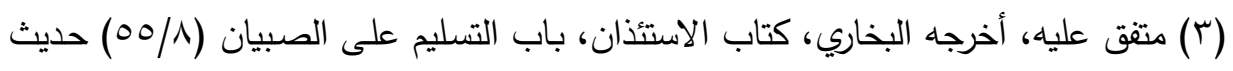

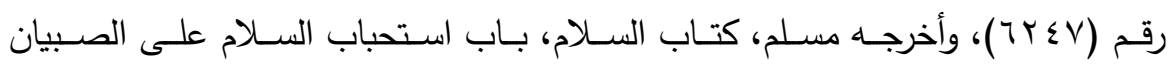

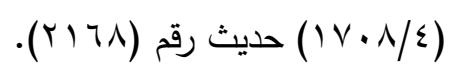




\section{مجلح كلية اصول الدين والدعوة بالمنوفية العدد التاسع والثلاثون}

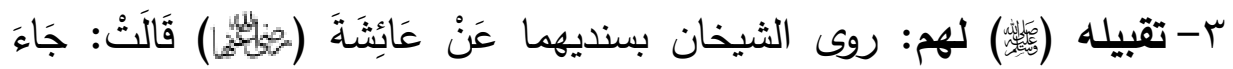

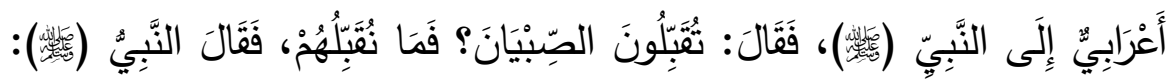

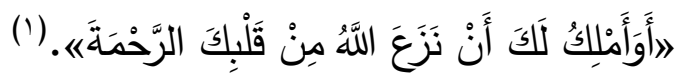

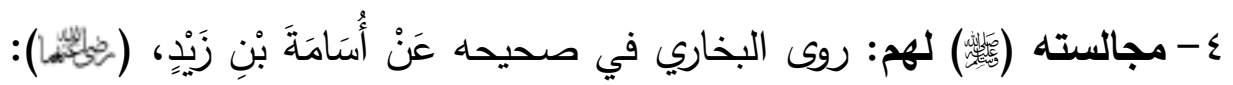

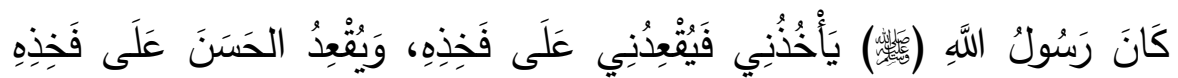

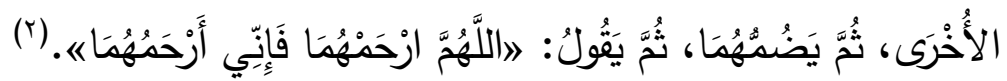

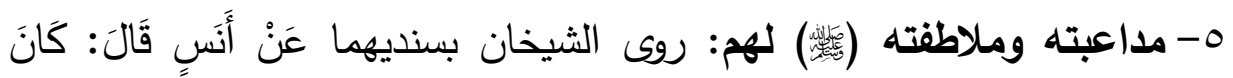

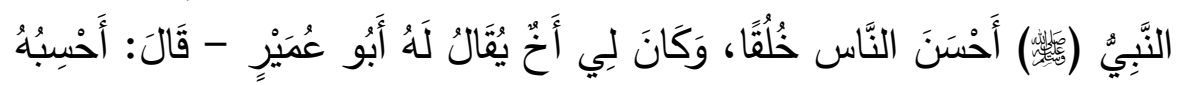

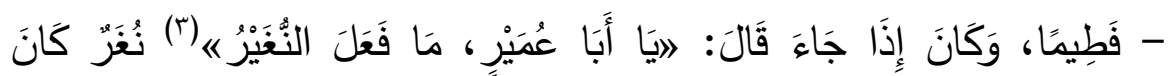

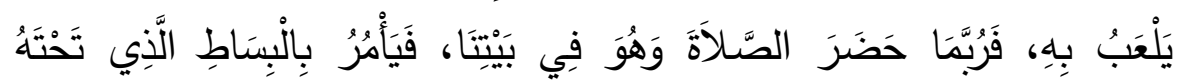

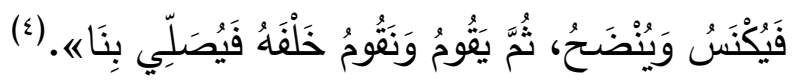

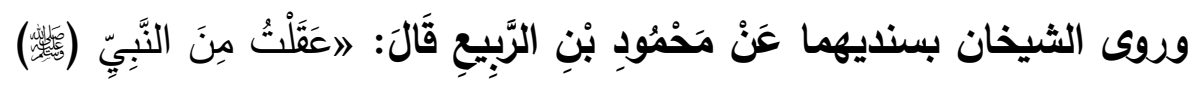

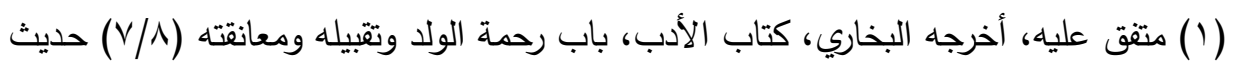

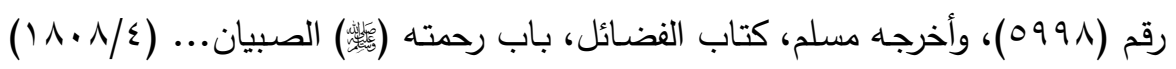

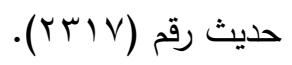

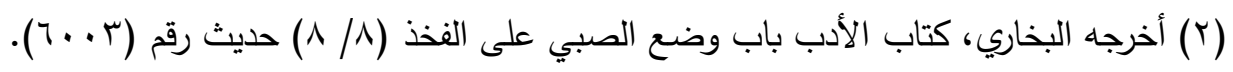

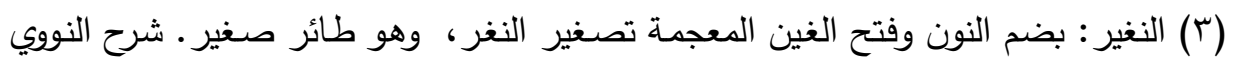

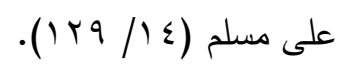

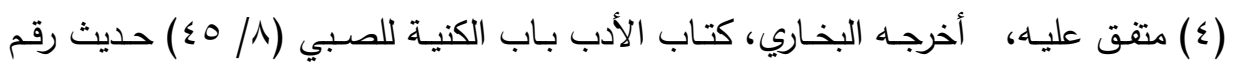

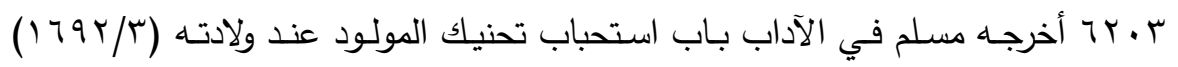

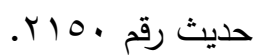




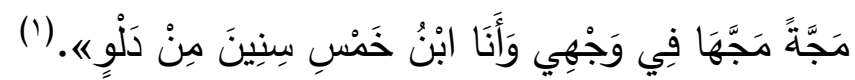

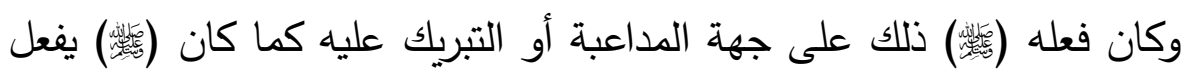

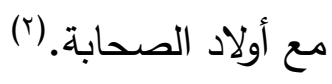

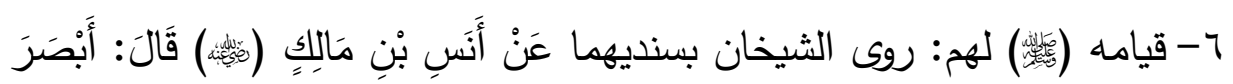

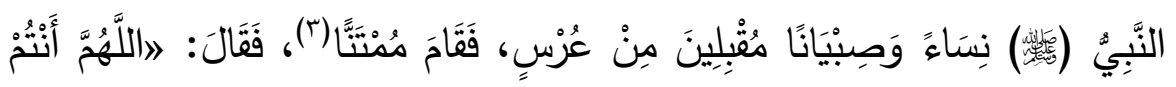

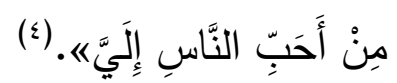

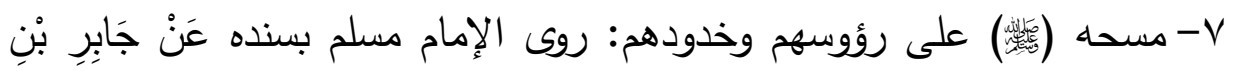

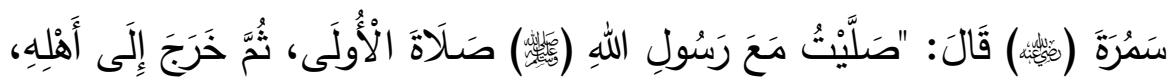

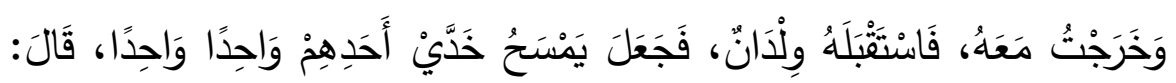

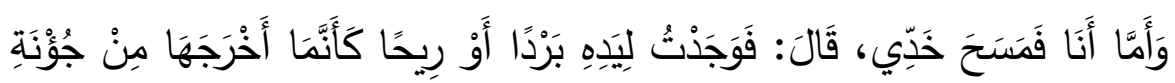

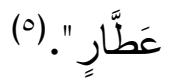

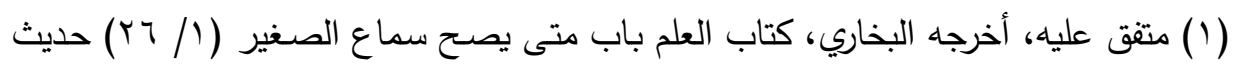

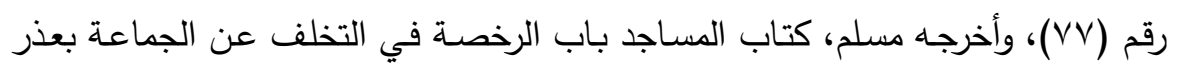

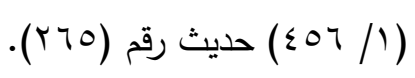

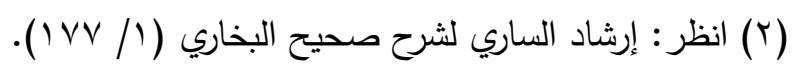

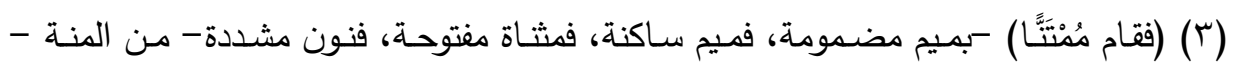

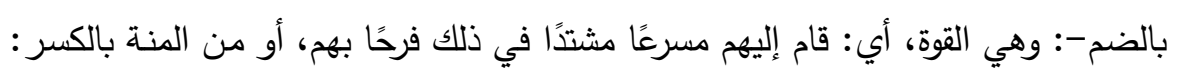

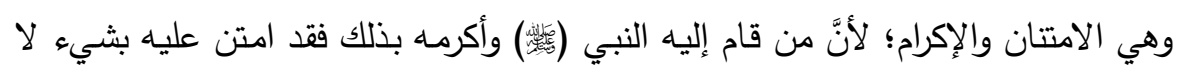

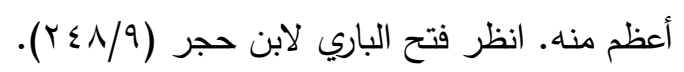

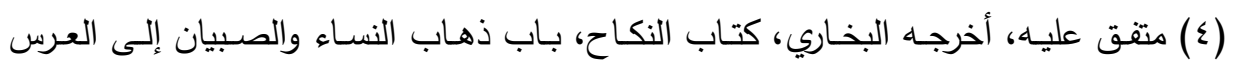

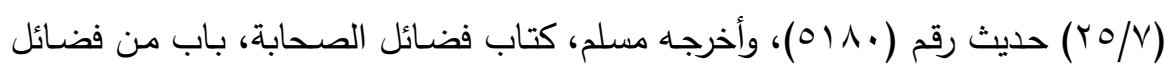

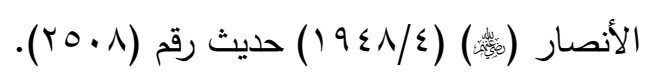

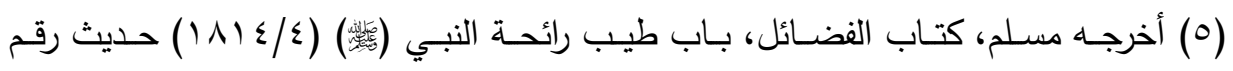




\section{مجلل كلية اصول الدين والدعوة بالمنوفية العدد التاسع والثلاثون}

ولا يخفى ما لهذه الصور وغيرها من آثار معنوية تخبر عن معاني الحب والعطف والرحمة، والصبي بأمس الحاجة لهذه المظاهر التي تعطي لله الأمن والطمأنينة والاستقرار النفسي.

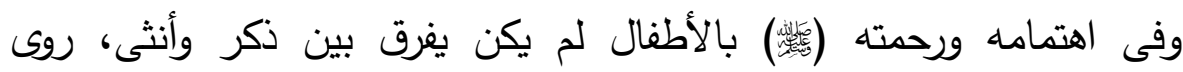

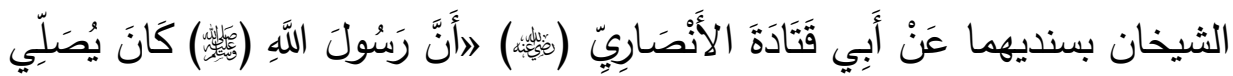

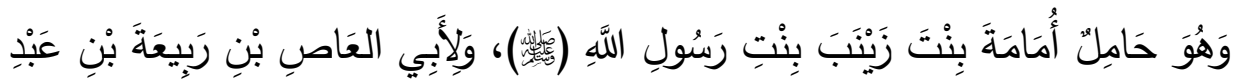

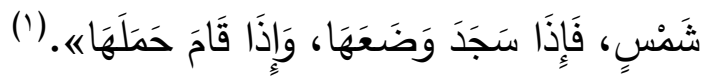
فانظر إلى حمله (先) أمامة ابنة أبى العاص على عاتقه في الصلاة، والصلاة

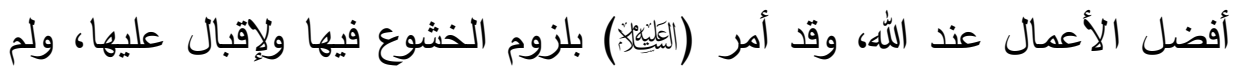
يكن حمله لها مما يضاد الخشوع المأمور باه فيها، وكره أن يشق عليها لو تركها

$$
\text { ولم يحملها فى الصلاة. (r) }
$$

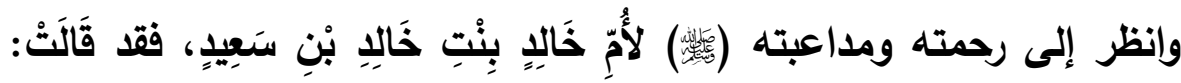

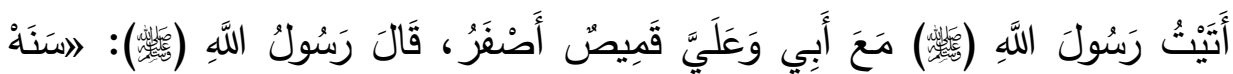

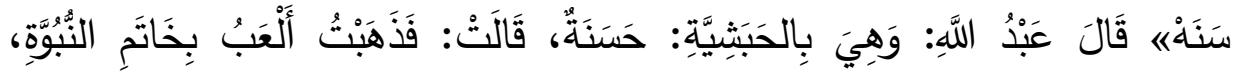

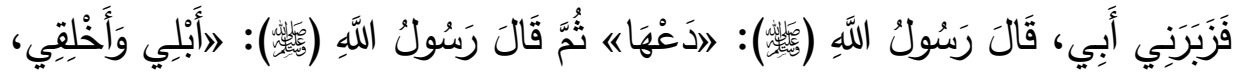

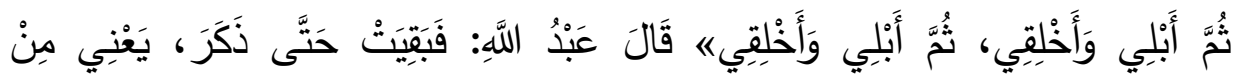

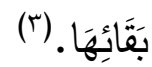

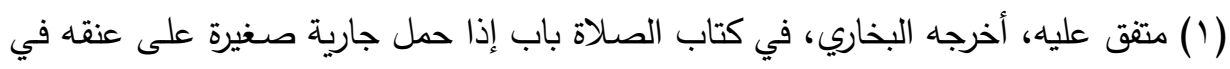

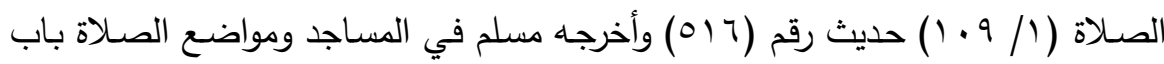

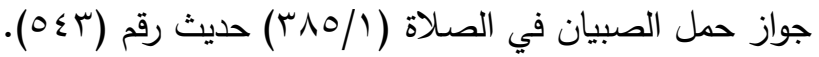

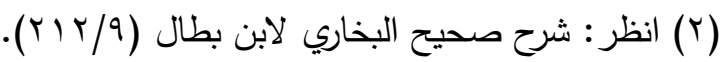

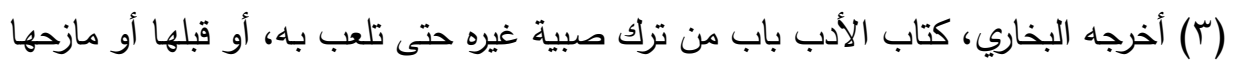

$$
\text { ( حديث رقم ( V ( }
$$




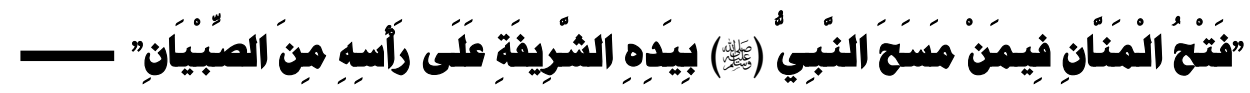

\section{البمسمث الأول

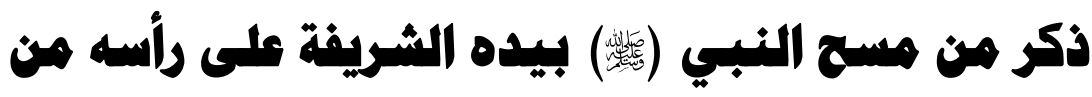 |لمبهان}

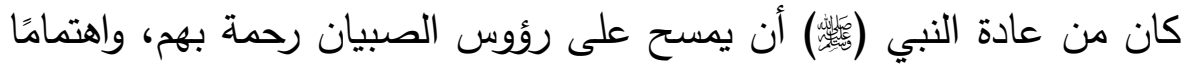

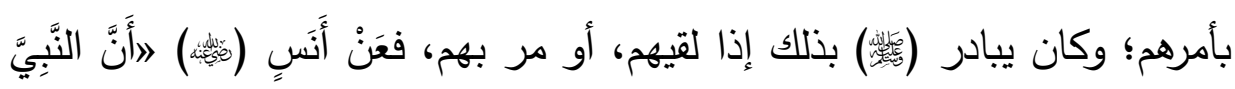

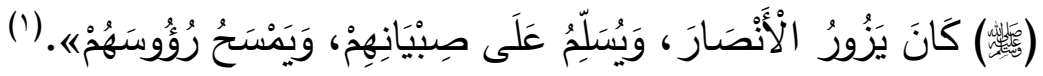

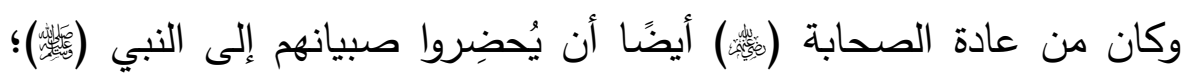

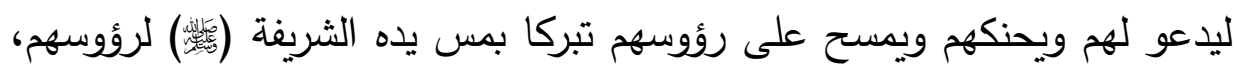

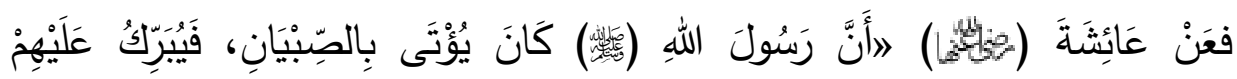

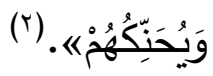

لذا عقد الإمام البخاري في الصحيح بابا بعنوان "باب الدعاء للصبيان بالبركة، ومسح رؤوسهم" كما أشرت إلى ذلك في مقدمة البحث.

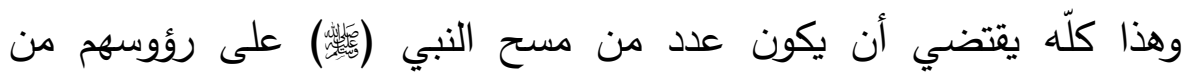

( (1) أخرجه ابن حبان في صحيحه، كما في الإحسان، كتاب البر والإحسان، باب الرحمة

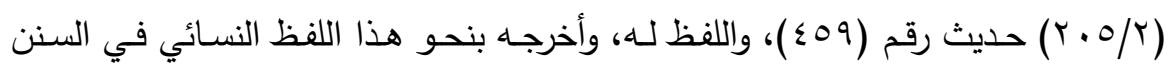

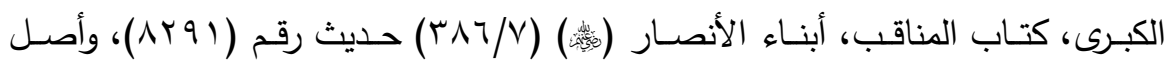

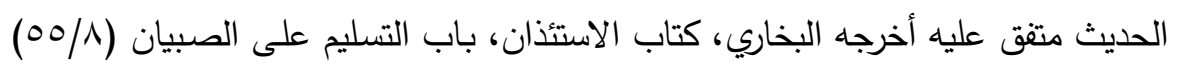

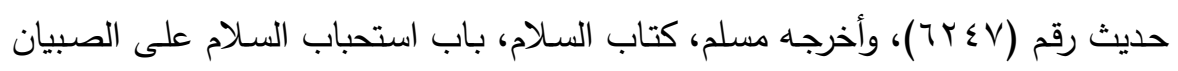

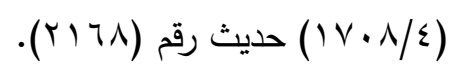

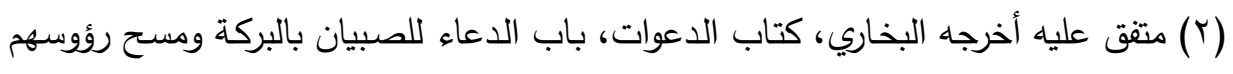

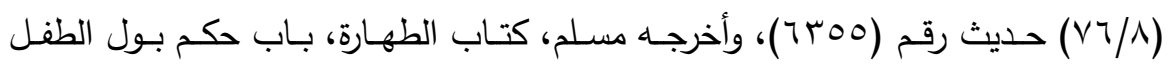

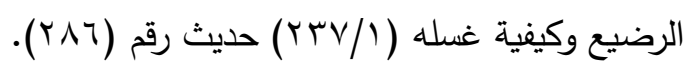




\section{مجلل كلية اصول الدين والدعوة بالمنوفية العدد التاسع والثلاثثون}

الصبيان كثيرا؛ لكن ما جاء مسندا في كتب الحديث وكتب التراجم في تعيين

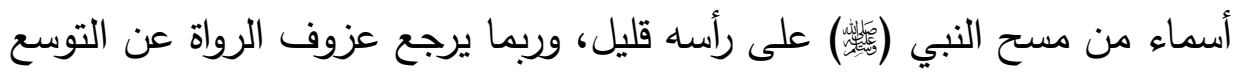

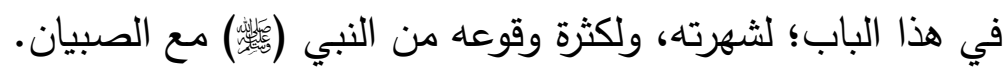
وسأذكر في هذا المبحث ما وقفت عليه مسندا في هذا الباب ممن مسح النبي (就) على رؤوسهم في كتب السنة المسندة وكتب التراجم مرتبا أسماءهم

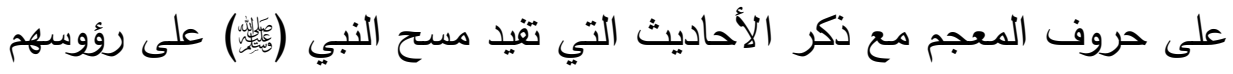
وتخريجها والحكم عليها.

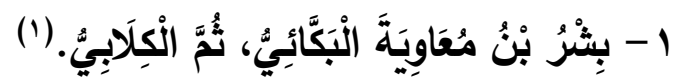

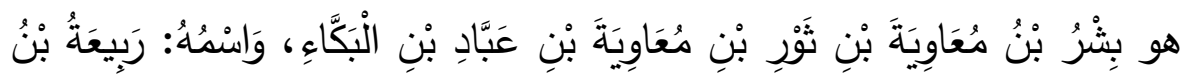
عَامِرِ بْنِ صَعْصَعَةَة. قال ابن حبان: له صحبة، عداده فِي أهل الْحجاز، وفد هو وأبوه على النَّبِي

روى عنه: يعقوب بن محمد الزهري، وروى عنه حفيده ماعز بن العلاء بن بشر، عن أبيه العلاء، عن أبيه بشر، وقال الباوردي: حديثه عند بعض ولده.

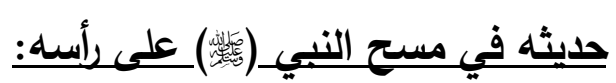
عن بشر بن معاوية بن ثور البكاء العامري قال: وفدت مع أبي إلى رسول الله

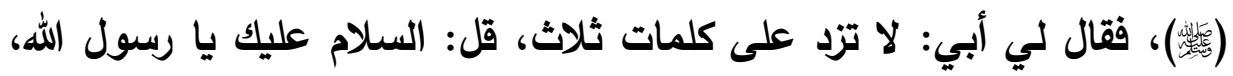
أتيتك يا رسول الله لأسلم عليك، وأسلم إليك، وتدعو لي بالبركة. قال: ففعلت.

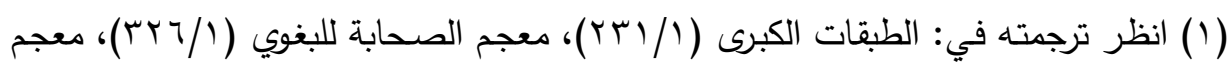

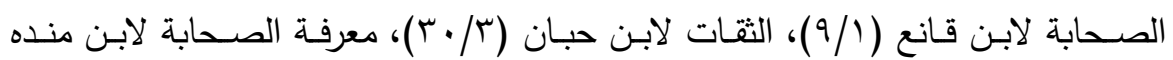

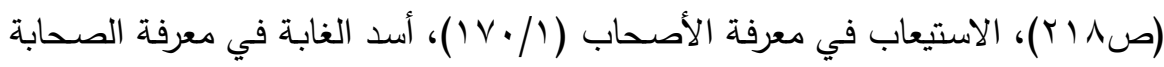

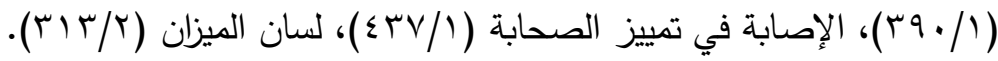




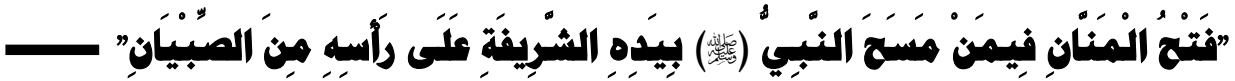

قال: فمسح رسول الله (敬) على رأسي، ولي يومئذ ذؤيبة(1)، ودعا لي بالبركة.

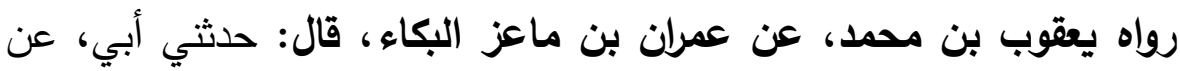

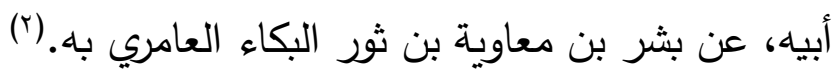

وقال الحافظ ابن حجر: "وله طريق أخرى أخرجها ابن شاهين من طريق زياد بن عبد اللَّ البكائيّ، عن معاوية بن بشر بن يزيد بن معاوية بن ثور قال: قدم

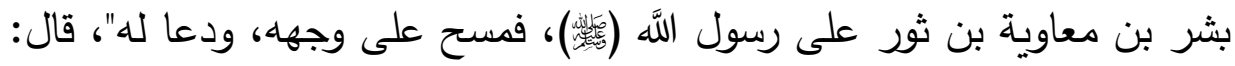
"وهذا فيه انقطاع".

ثم قال: "وروى ابن شاهين أيضا وثابت في الدلائل من طريق هثام بن

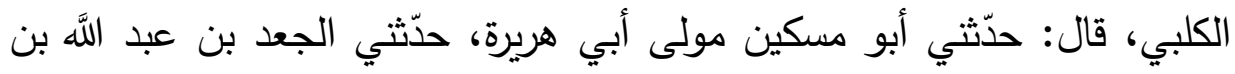

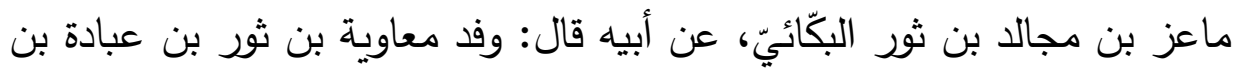

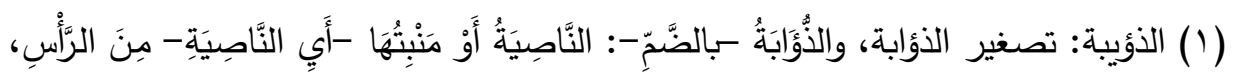

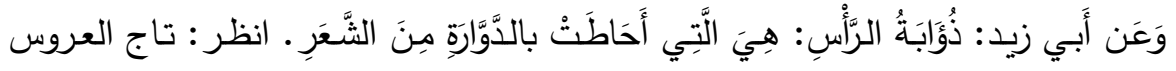

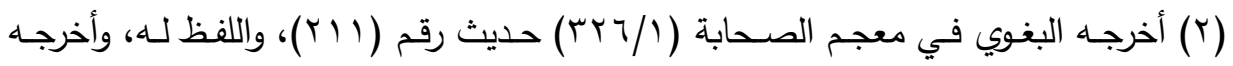

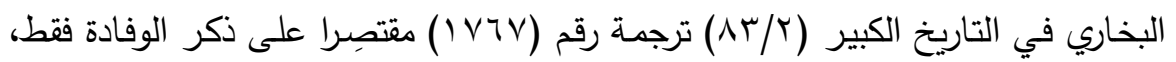

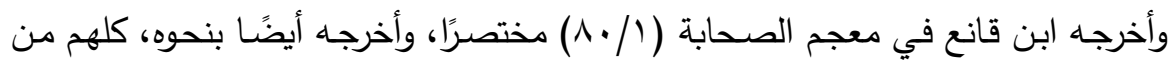
طريق يعقوب بن محمد... به. به.

والحديث بهذا الإسناد ضعيف؛ فيه يعقوب بن محمد بن عيسى بن عبد الملك الزهري المدني:

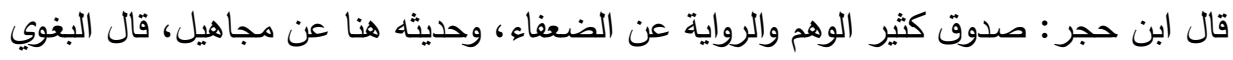

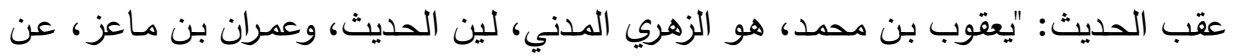

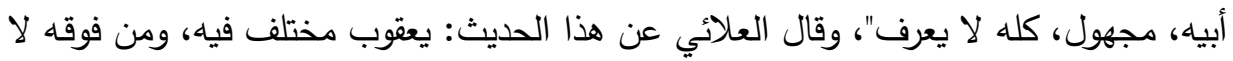

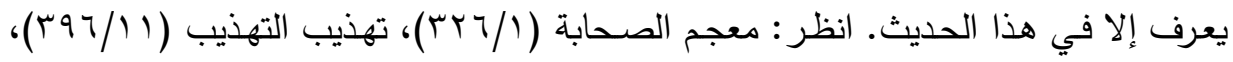

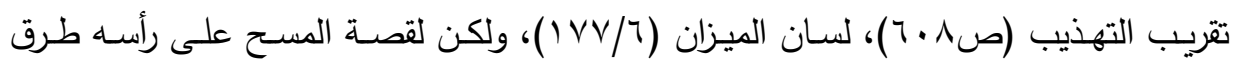

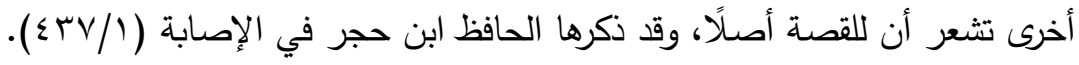




\section{مجلل كلية اصول الدين والدعوة بالموفية العدد التاسع والثلاثثون}

البكّاء على النبيّ (敬) وهو شيخ كبير، ومعه ابن له يقال له: بشر، والهجنّع بن

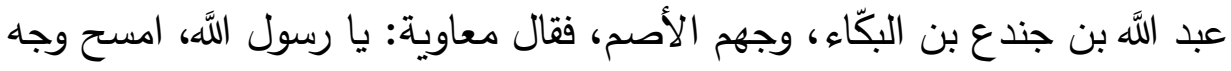

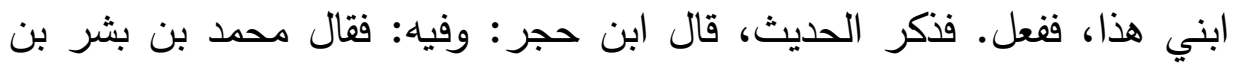

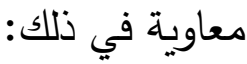

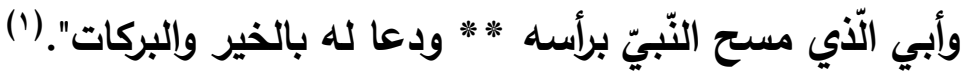

وقال ابن سعد: "أخبرنا محمد بن عمر الأسلدي قال: حدثني عبد الله بن باله

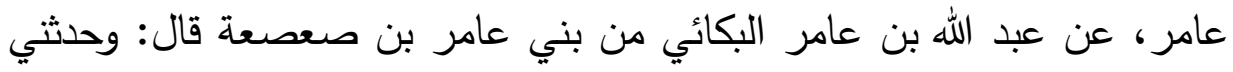
محرز بن جعفر، عن الجعد بن عبد الله بن عامر البكائي من بني عامر بن بن بالي

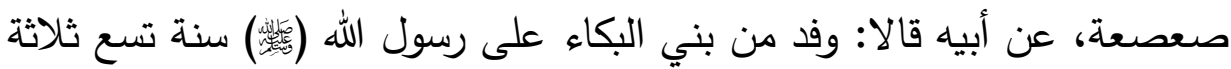
نفر : معاوية بن ثور بن عبادة بن البكاء. وهو يومئذ ابن مائة سنة. ومعه ابن له يقال له بشر • والفجيع بن عبد الله بن جندح بن البكاء. ومعهم عبد عمرو البكائي.

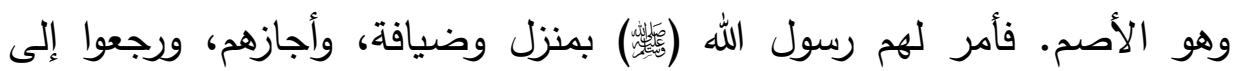

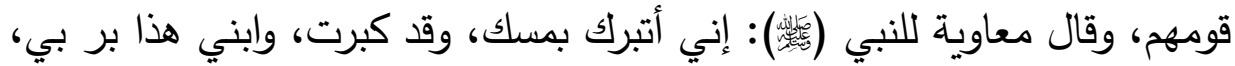

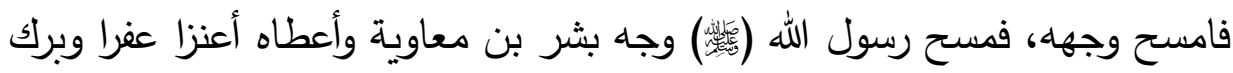

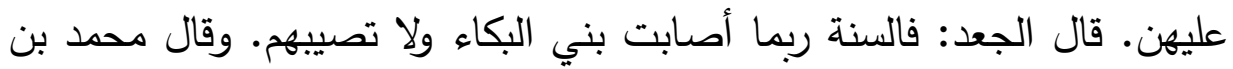
بشر بن معاوية بن ثور بن عبادة بن البكاء:

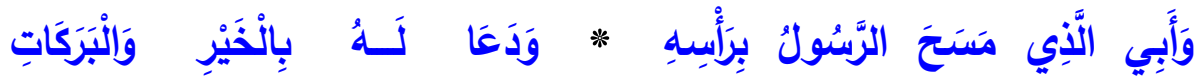

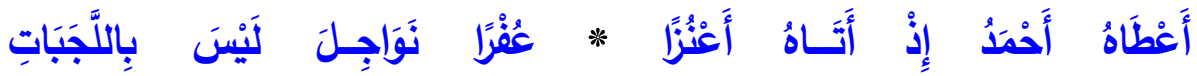

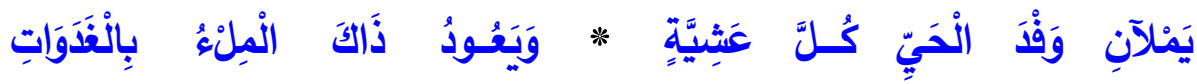

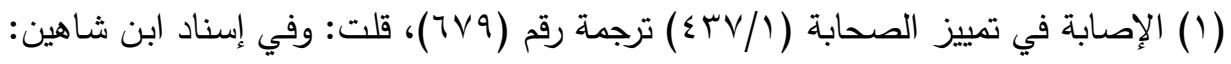

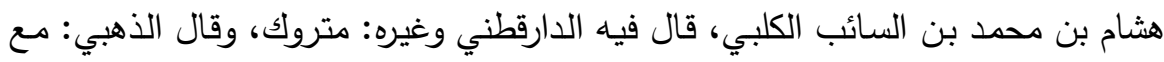

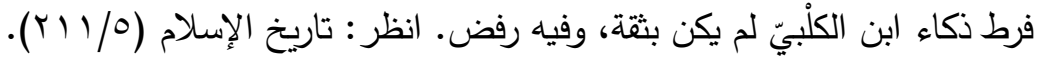




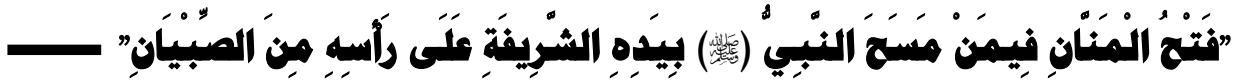

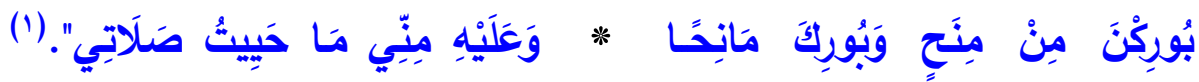
ويظهر أثر مسح النبي (苟) في رواية ابن منده للحديث؛ حيث أخرجه بنحو

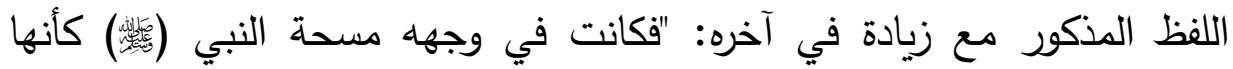

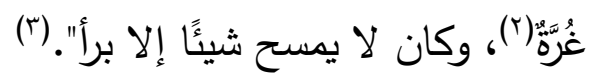

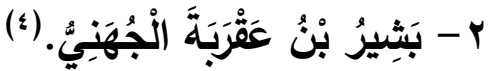

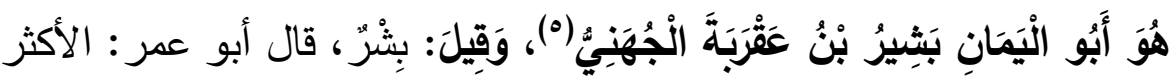

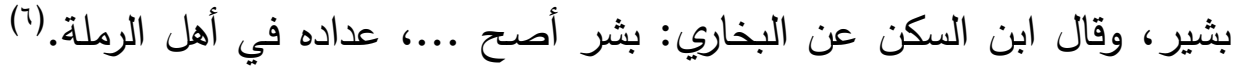

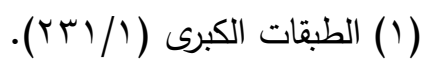

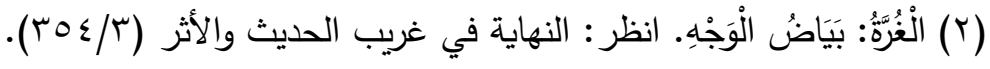

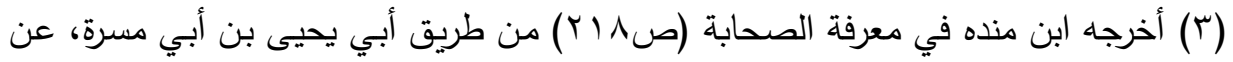

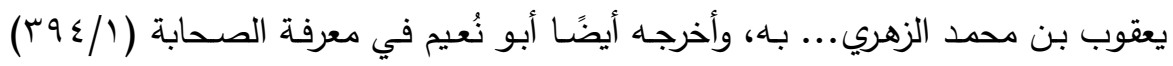
حديث رقم (1) (1) ) من نفس طريق ابن منده وبلفظه.

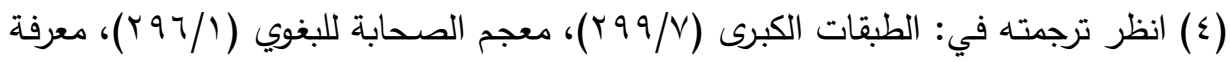

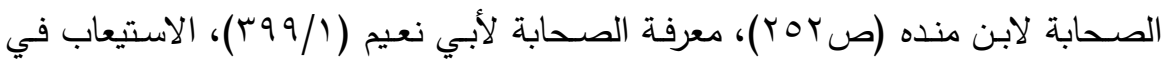

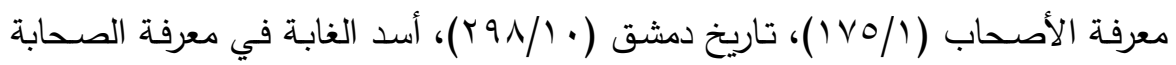

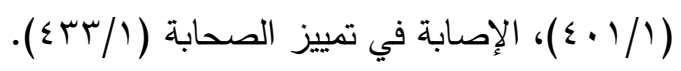

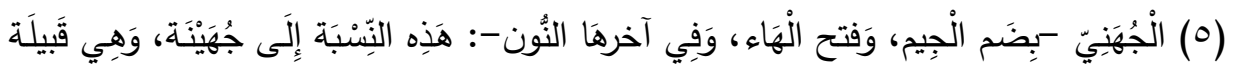

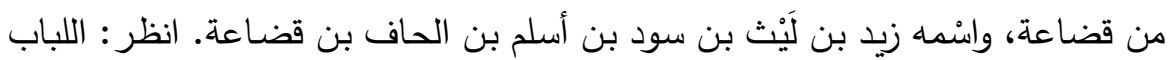

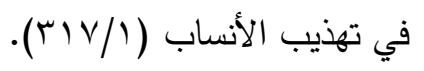

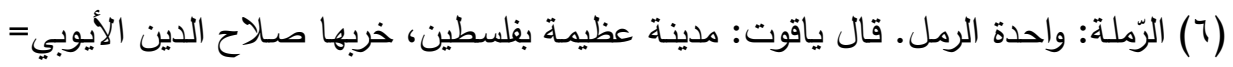

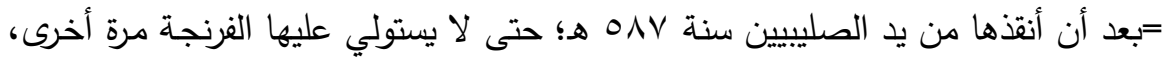

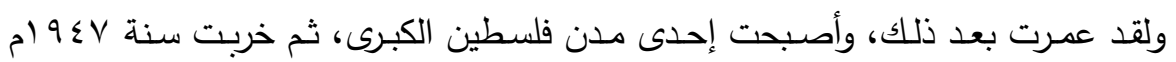
عندما أحاطت بها قوى العدوان من كل أقطارها. انظر : المعالم الأثيرة في السنة والسيرة . ( (1) 


\section{مجلل كلية اصول الدين والدعوة بالمنوفية العدد التاسع والثلاثون}

قال البخاريّ: قال لي عثمان: بشر معروف بفلسطين. لله صحبة، ولأبيه عقربة صحبة. حديثه عند الثاميين، وقد روى عن النبي (赔) حديثين، وروى عنه: عبد الله بن عوف الكناني، وشريح بن عبيد الحضرمي. قال ابن عبد البر : مات بعد سنة خمس وثمانين، وقال ابن حبان: مات بقرية من كور (') فلسطين.

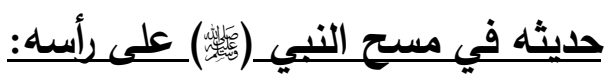

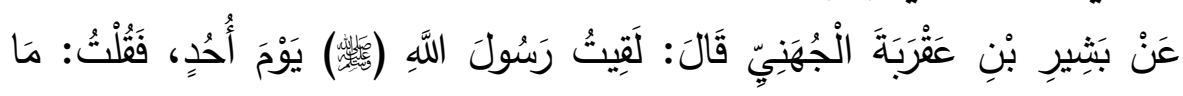

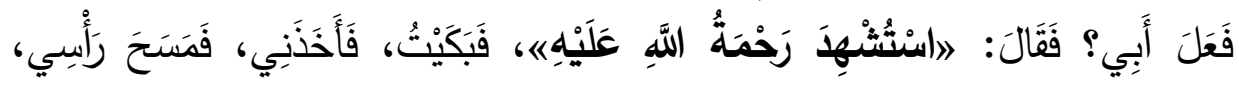

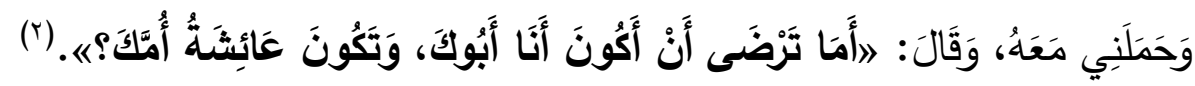

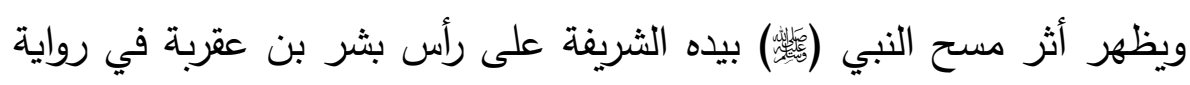
ابن عساكر وإسحاق الرملي للحديث؛ حيث ورد في روايتهها أنه ابيضّ كل شيء بن

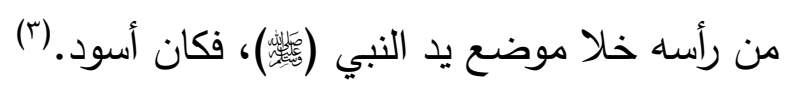

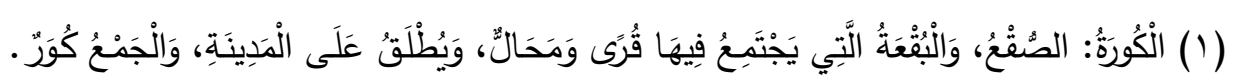

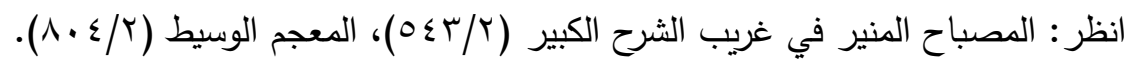

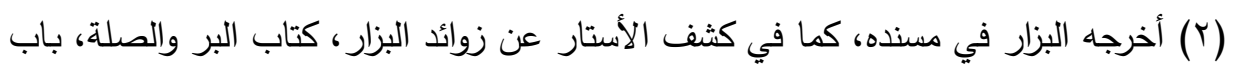

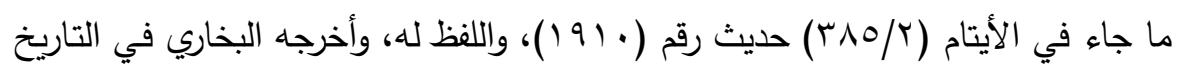

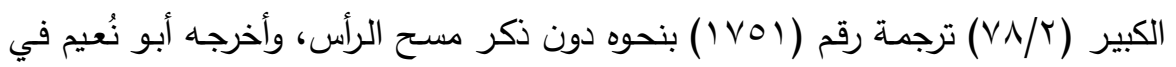

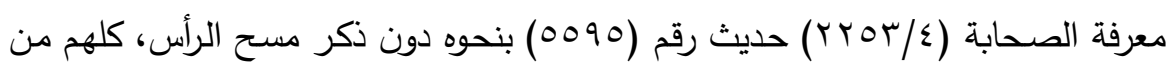

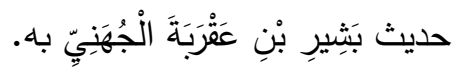
والحديث ضعيف الإسناد؛ ففي إسناد البزار من لا يعرف، انظر : مجمع الزوائد (1/ (7 (1)، وهم

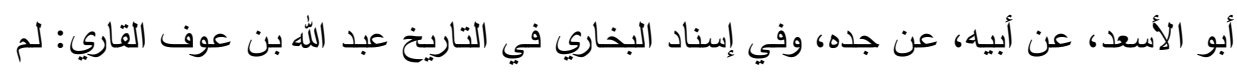

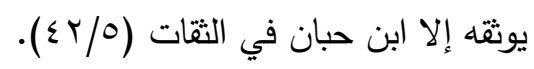

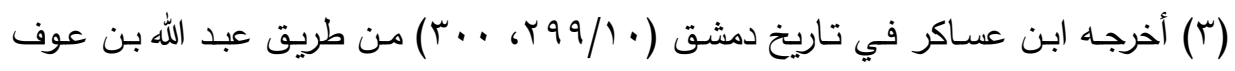




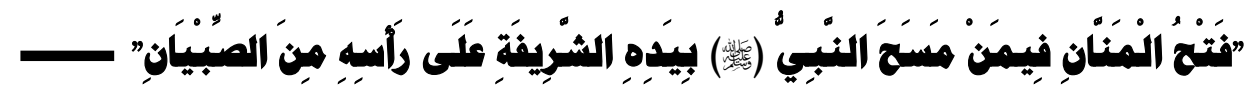

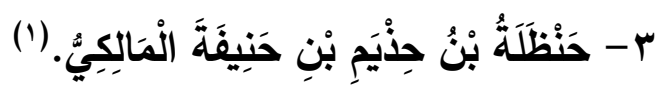

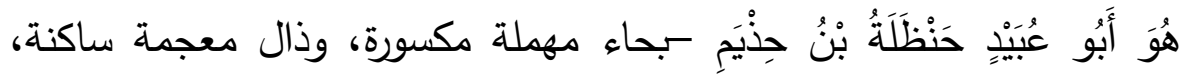

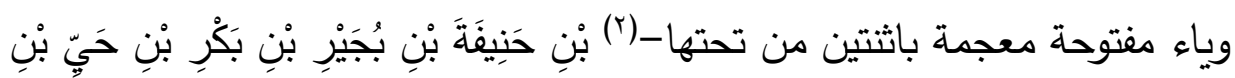

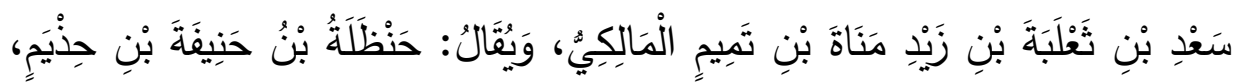

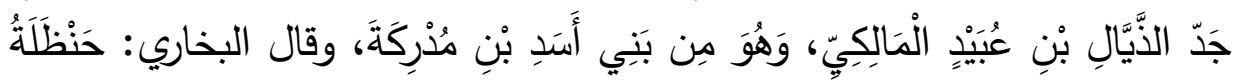
بْنُ حِذْيَمِ، ولم ينسبه.

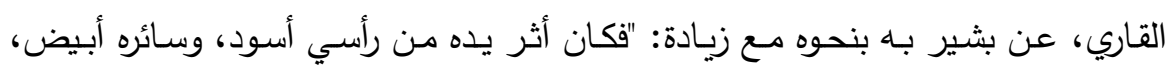

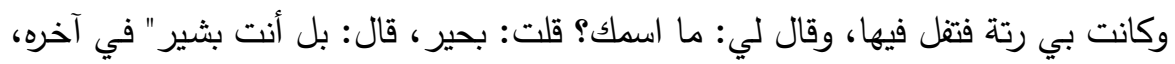

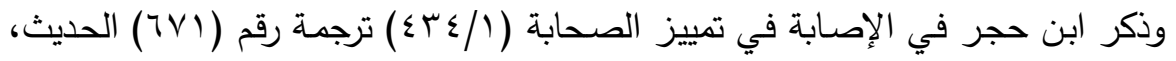

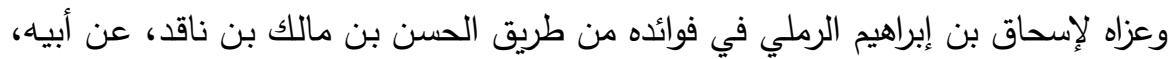

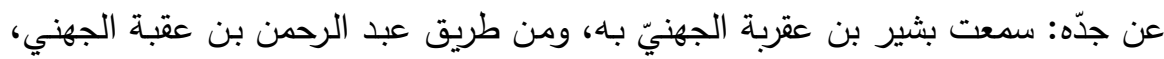

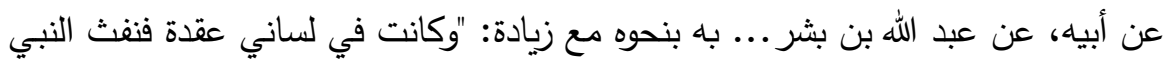

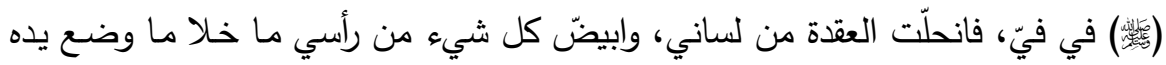

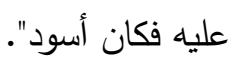

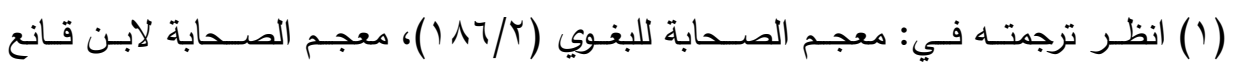

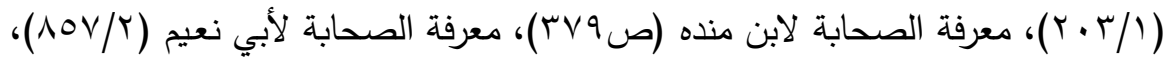

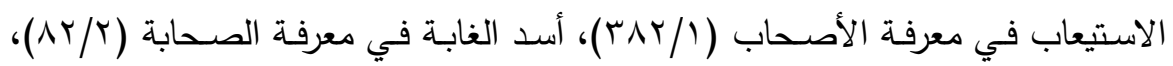

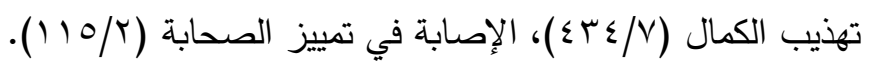

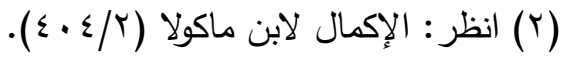




\section{مجلد كلية اصول الدين والدعوة بالمنوفية العدد التاسع والثلاثئون}

$$
\text { سكن البصرة، وله ولأبيه ولجده صحبة. }
$$

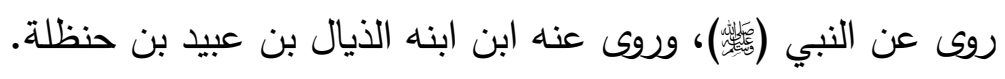

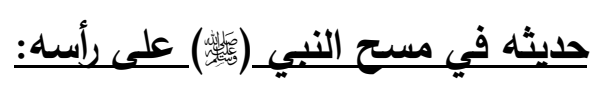

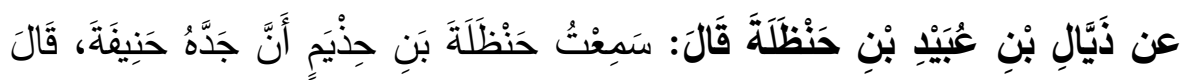

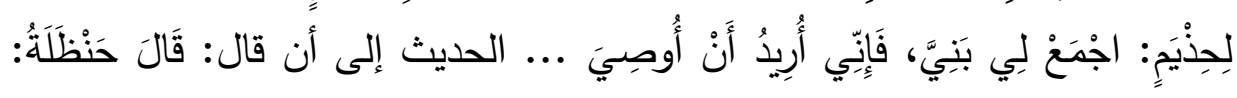

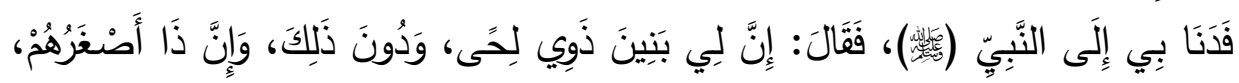

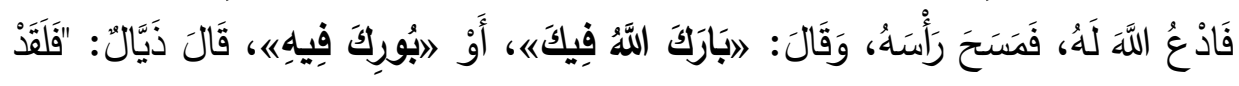

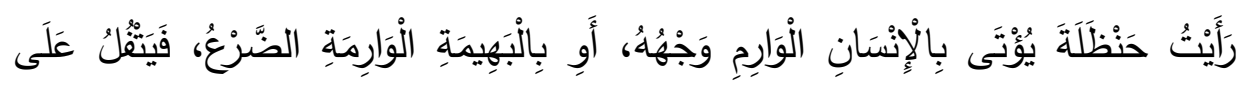

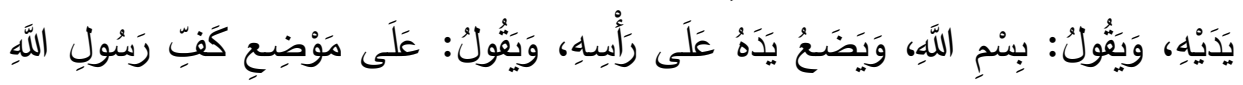

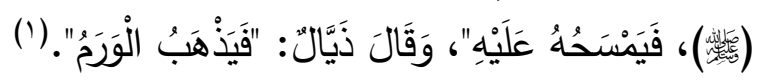

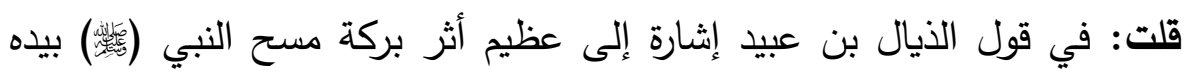

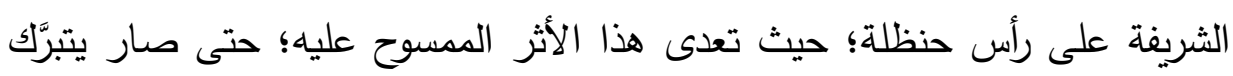

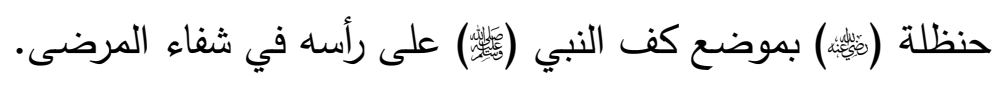

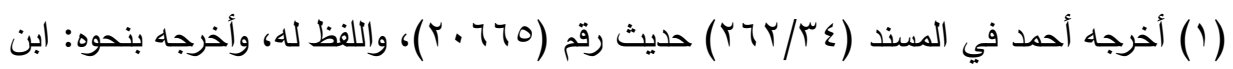

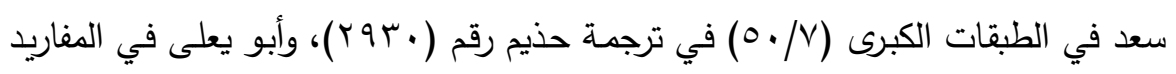

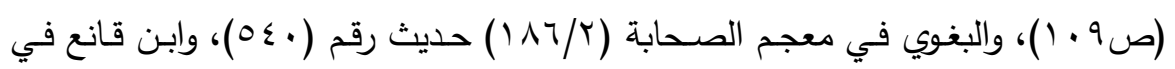

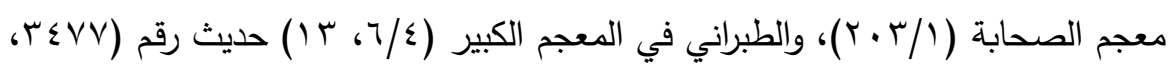
1.

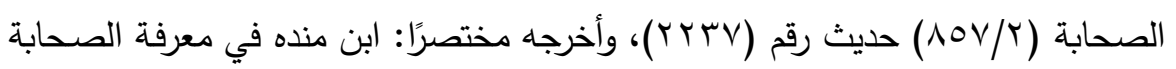

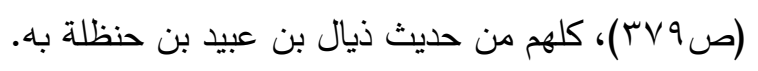

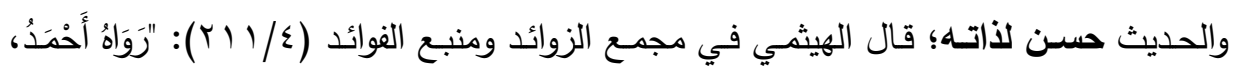

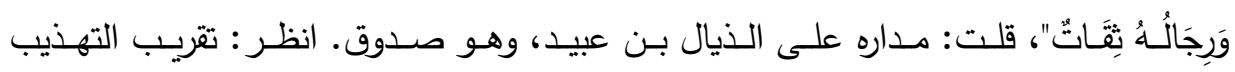
(صץ • r)، وبقية رجاله ثقات. 


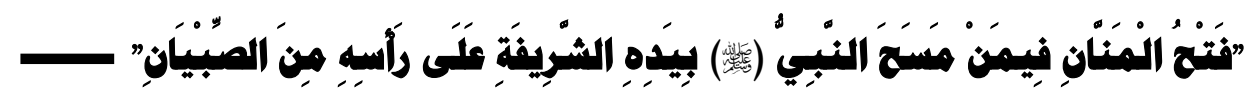

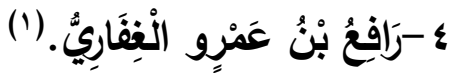

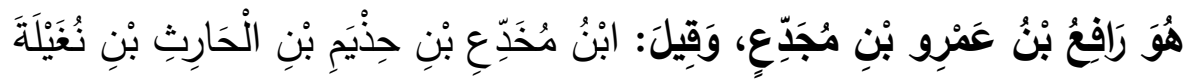

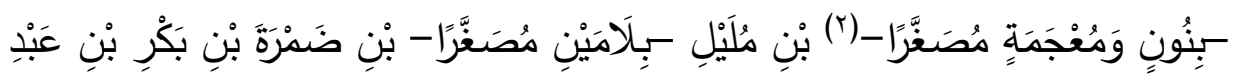

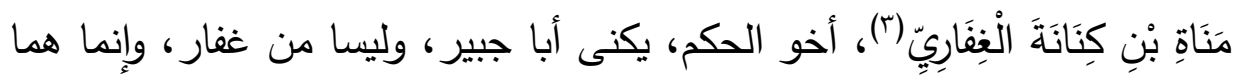

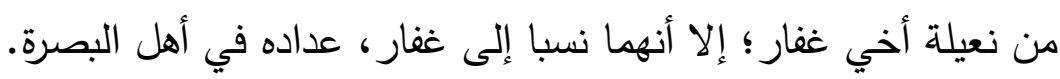

$$
\text { قرى عن الذهب: له صحبة. }
$$

وروى عنه عمرو بن سليم، وعبد الله بن الصامت، وابنه عمران بن رافع، وأبو ، موليو

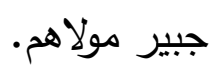

وقال خليفة: مات بالبصرة سنة خمسين.

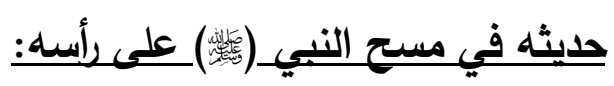

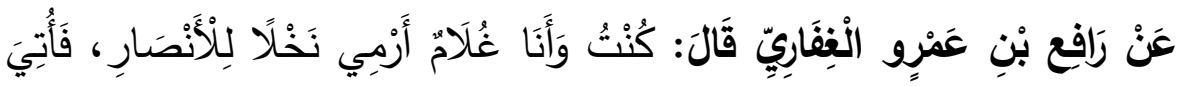

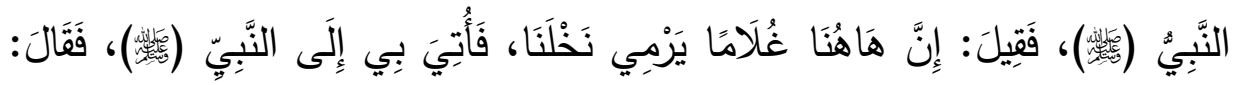

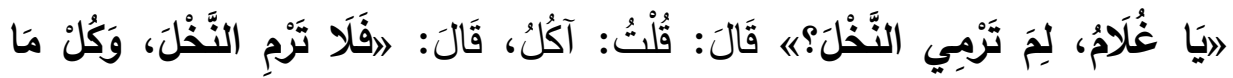

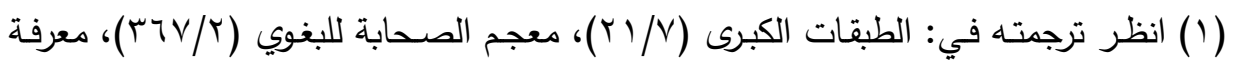

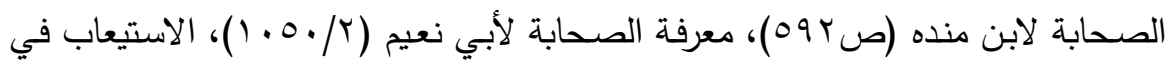

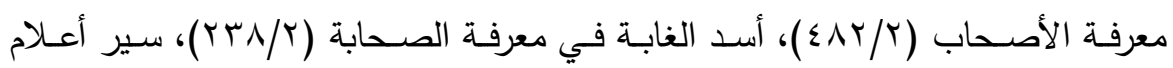

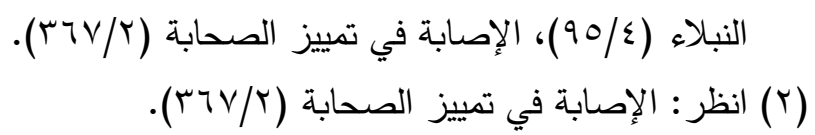

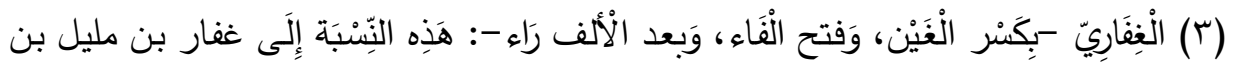

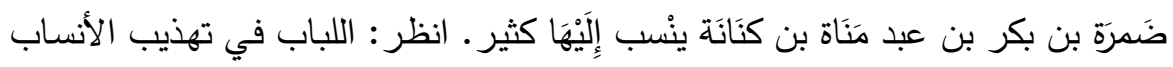
.$(r \wedge \mathrm{r} / \Gamma)$ 


\section{مجلل كلية اصول الدين والدعوة بالمنوفية العدد التاسع والثلاثثون}

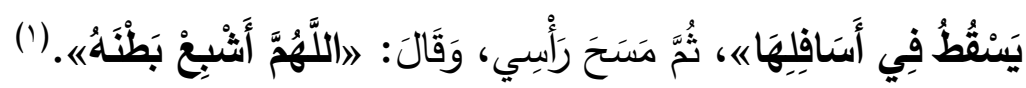

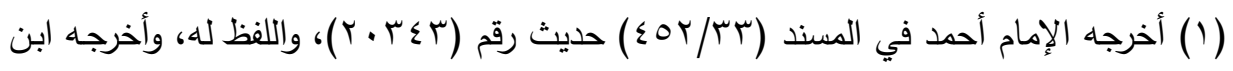

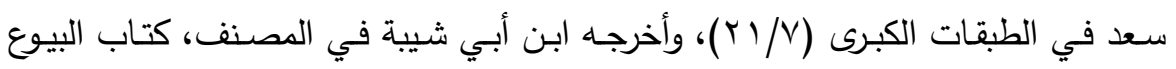

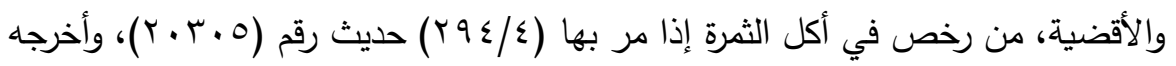

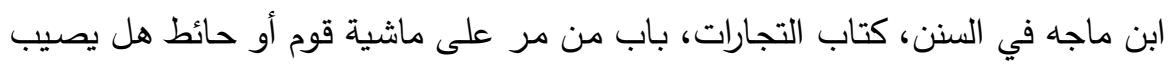

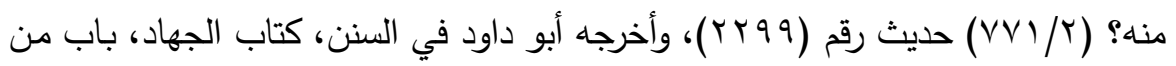

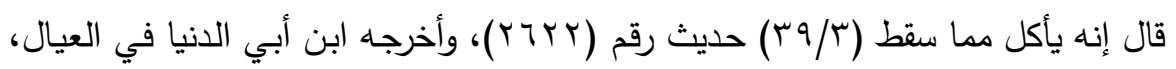

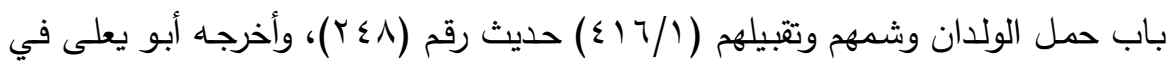

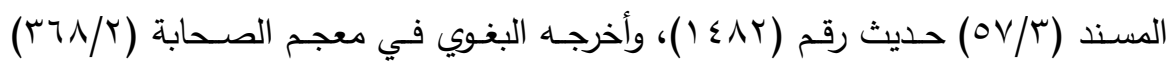

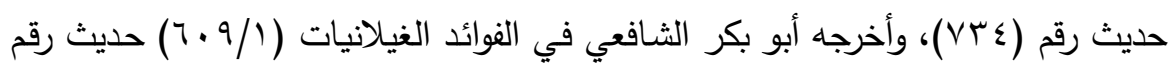

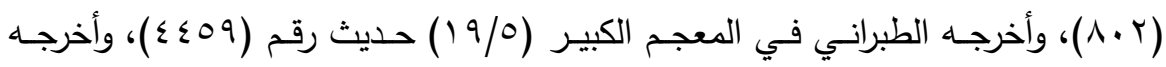

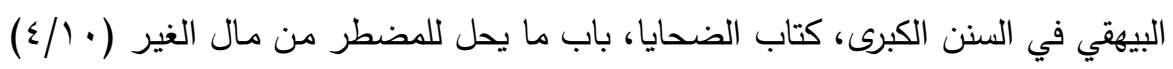
حديث رقم (ـ77 (97)، وذكره البوصيري في إتحاف الخيرة المهرة بزوائد المسانيد العشرة،

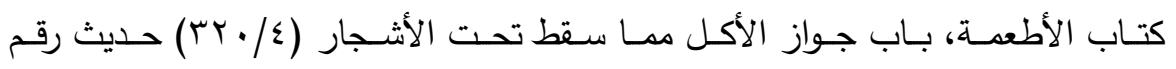

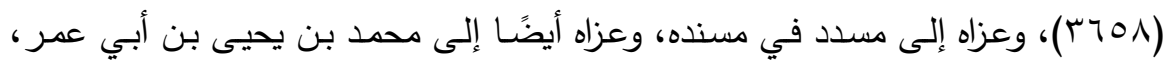

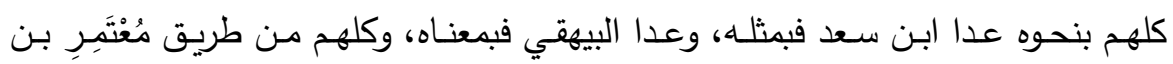

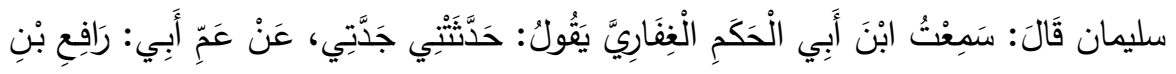

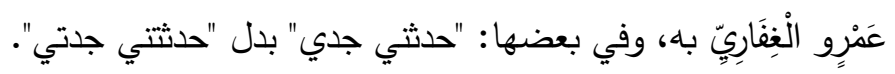

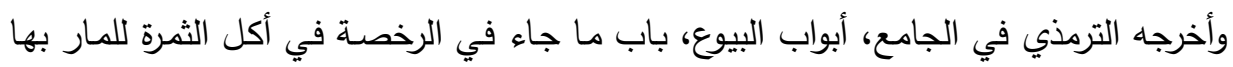

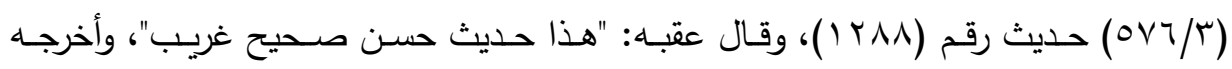

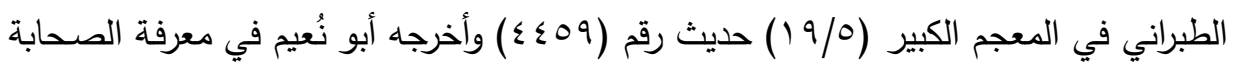

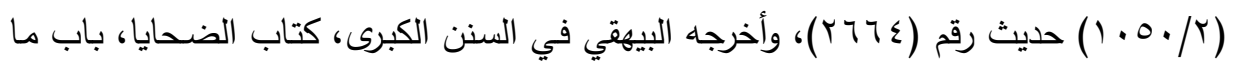

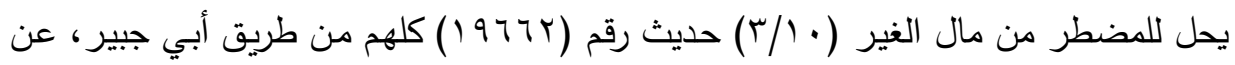
رافع بن عمرو به بمعناه دون ذكر المسح. والحديث حسن لغيـره؛ في إسناد أحمد: ابن أبي الحكم الغفاري: مستور ، انظر : تقريب

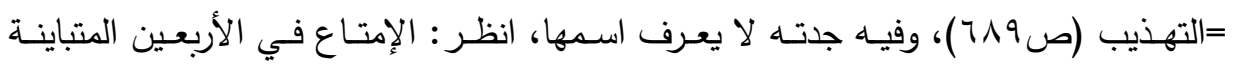




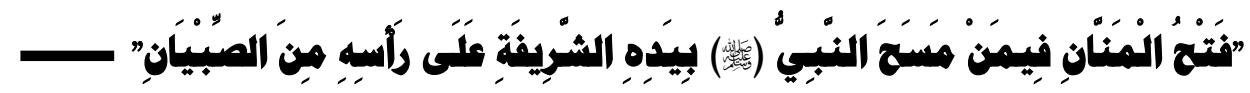

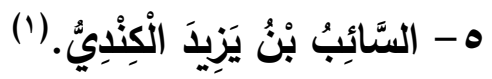

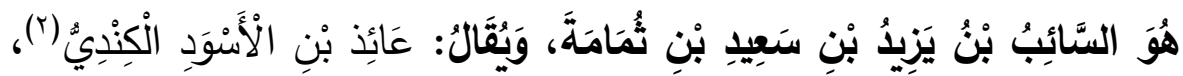

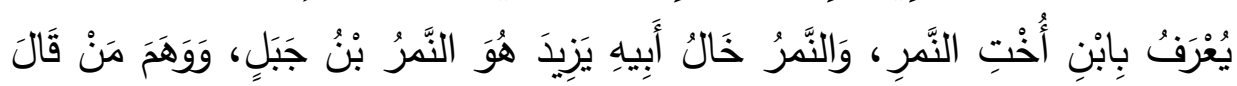

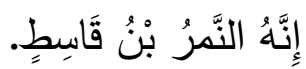

قال ابن عبد البر: ولد في السنة الثانية من الهجرة، فهو تِرْبُ (") ابن الزبير .

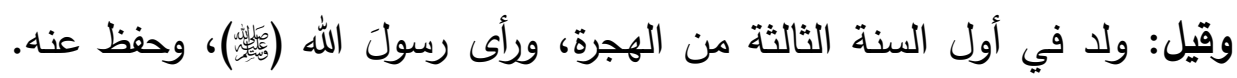
وقيل: كانت له يوم حجة الوداع سبع سنين، سكن المدينة. قال الزهري: له ولأبيه صحبة. روى عن النبي (敬)، وعن سعد بن أبي وقاص، ورافع بن خديج، وطلحة بن عبيد الله، وغيرهم.

السماع (ص^rr)، وقد تابعها عند الترمذي وغيره (دون ذكر المسح) أبو جبير الغفاري، وهو

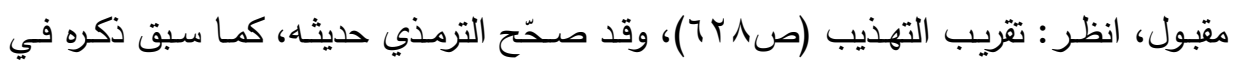

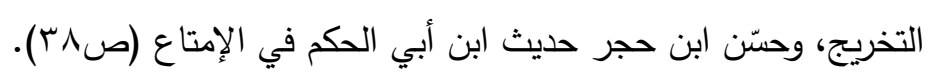

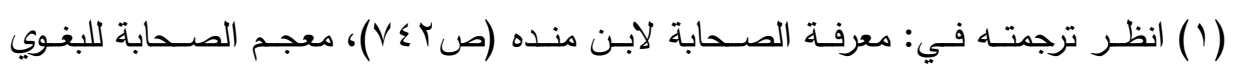

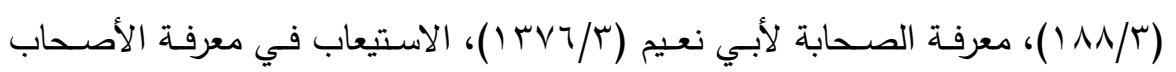

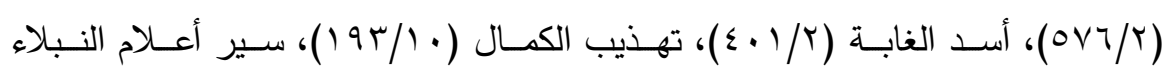

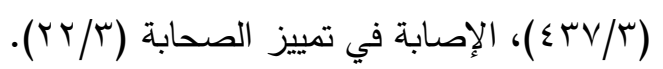

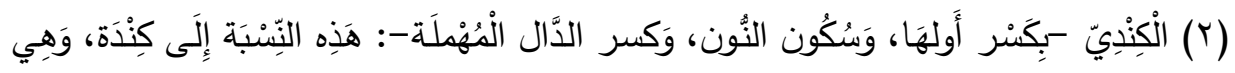

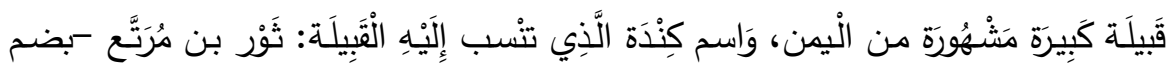

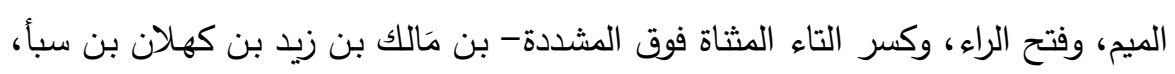

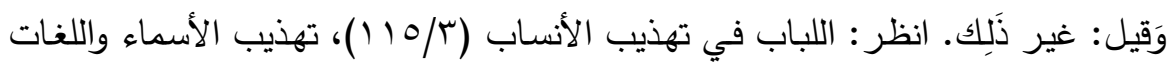
. (1 Kr/l)

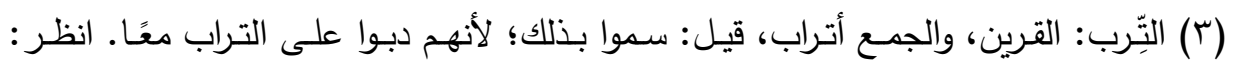

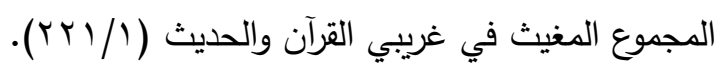




\section{مجلل كلية اصول الدين والدعوة بالمنوفية العدد التاسع والثلاثثون}

وروى عنه مولاه عطاء، والجعد بن عبد الرحمن، وداود بن قيس الفراء،

وغيرهم .

وقال مصعب الزبيري: استعمله عمر على سوق المدينة.

اختلف في سنة وفاته، فقال أبو نعيم: مات سنة اثنتين وثمانين، وقيل: سنة ست وثمانين، ويُروى عن الجعيد بن عبد الرحمن: وفاة السائب بن يزيد في سنة أربع وتسعين، وقال الواقدي وأبو مسهر وجماعة: توفي سنة إحدى وتسعين، وشذ

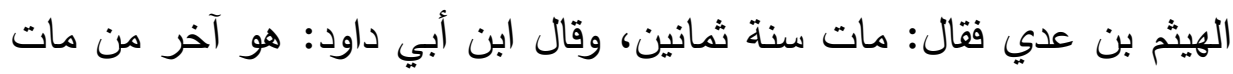
بالمدينة من الصحابة، ووهم يعقوب بن سفيان فذكره فيمن قتل يوم الحرّة.

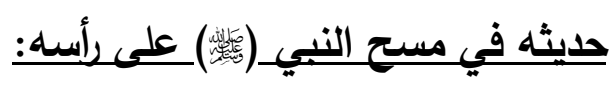

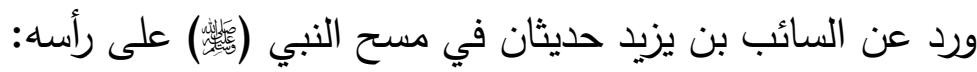

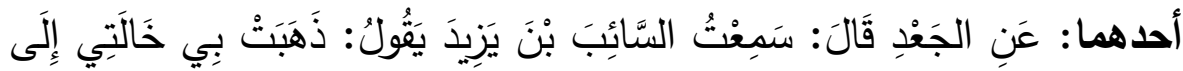

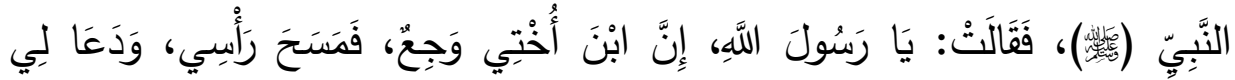

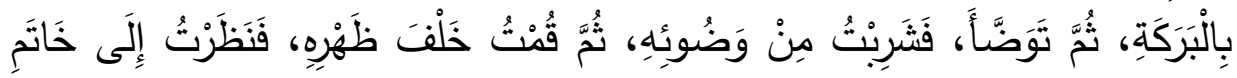

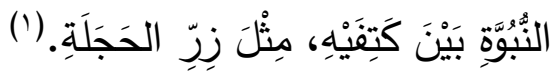

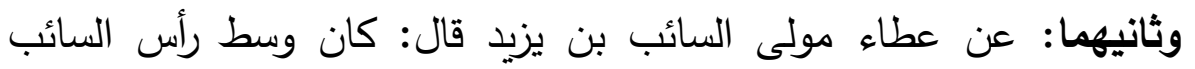
أسود، وبقية رأسه أبيض، قال: فقلت له: يا سيدي! والله ما رأيت مثل رأسك: هذاء أسود، وهذا أبيض! قال: أفلا أخبرك يا بني؛ قلت: بلى، قال: إني كنت مع

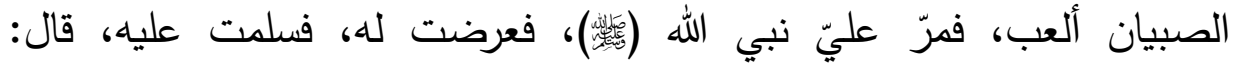
اوعليك، من أنت؟《 قال: قلت: أنا السائب بن يزيد، أخو النمر بن قاسط، قال:

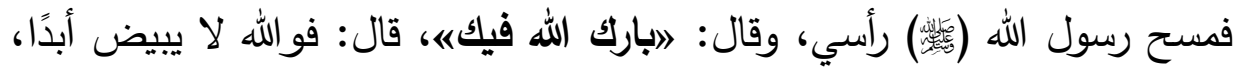

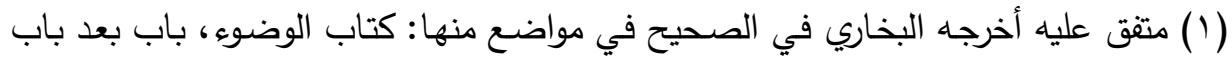

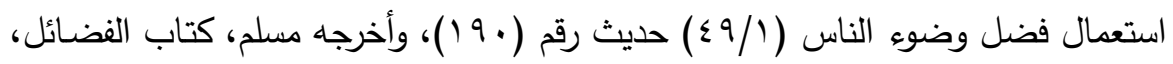

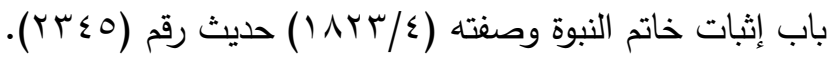


ولا يزال هكذا أبدًا. (')

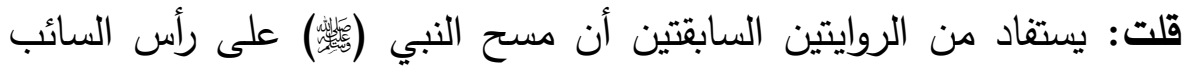

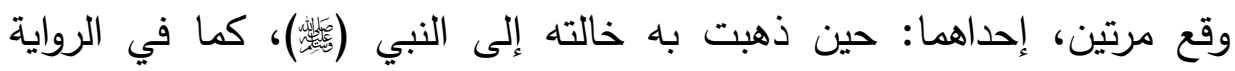

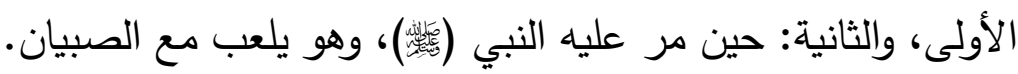

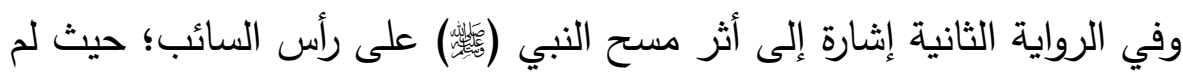

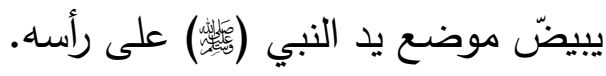
قال ابن بطال: "لا بأس بالذهاب بالصبيان إلى رلى الصالهي الصين وأهل الفضل رغبة في

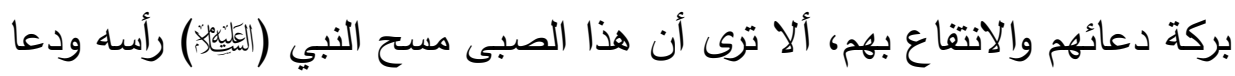

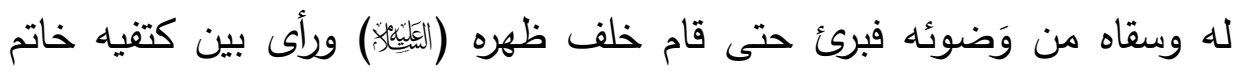
النبوة. وفيه أن شرب صاحب الوجع من وضوه الرجل الفاضل مئل مما يذهب وجعه". (广)

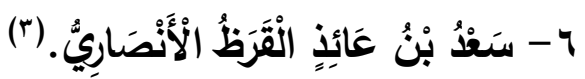

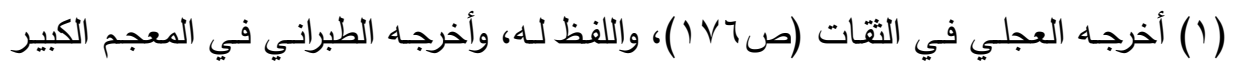

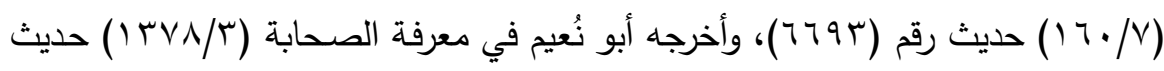

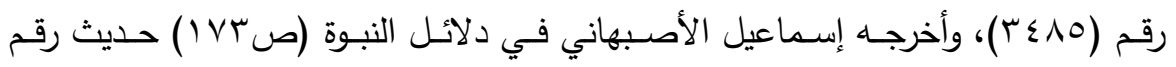

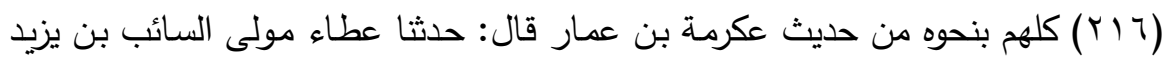
به، والحديث صحيح لذاته؛ فرواته ثقات، وسنده متصل.

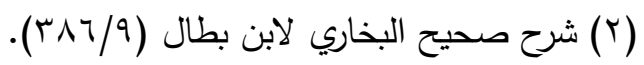

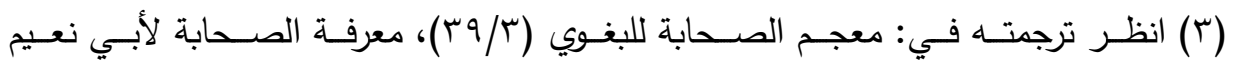

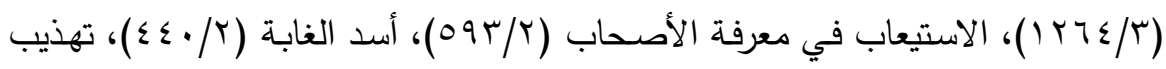

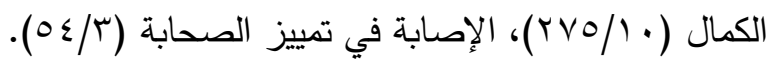




\section{مجلح كلية اصول الدين والدعوة بالمنوفية العدد التاسع والثلاثئون}

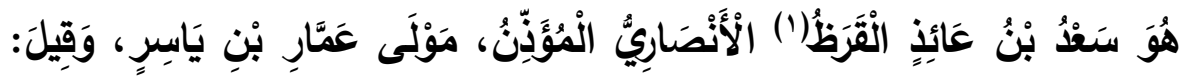

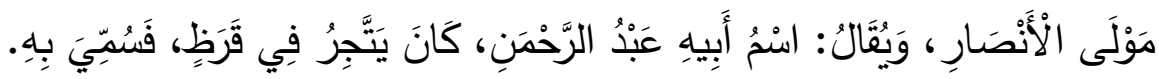
قال ابن عبد البر: له صحبة.

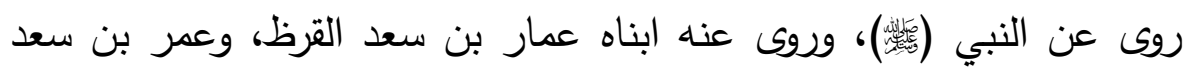
القرظ، وابن ابنه حفص بن عمر بن سعد القرظ.

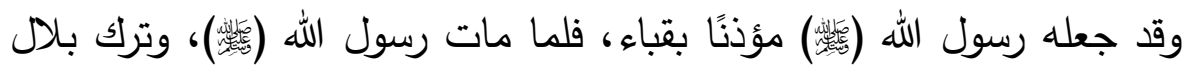

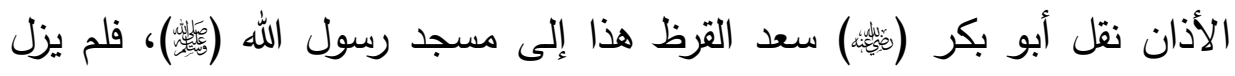

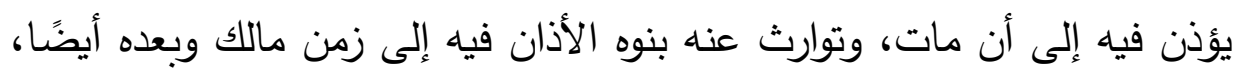

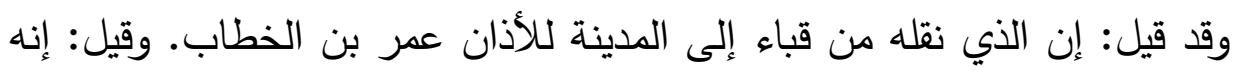

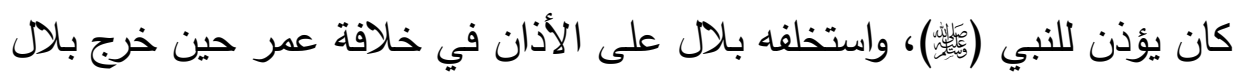

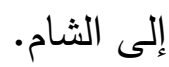

قال أبو أحمد العسكري: عاش القرظ إلى أيام الحجاج.

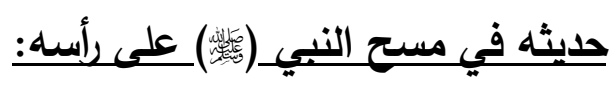

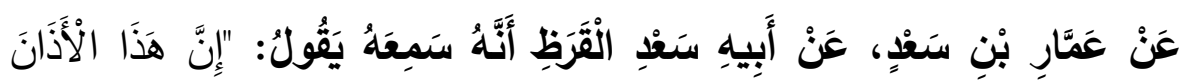

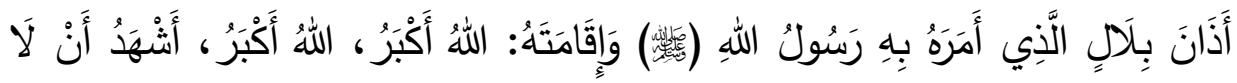

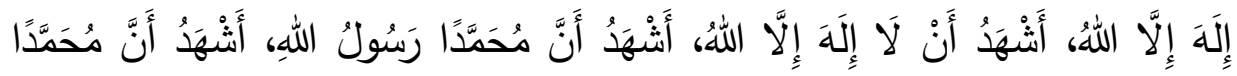

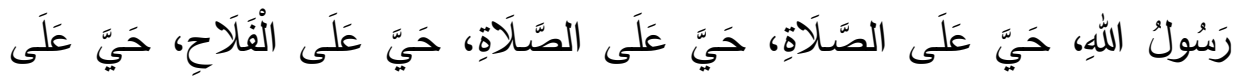

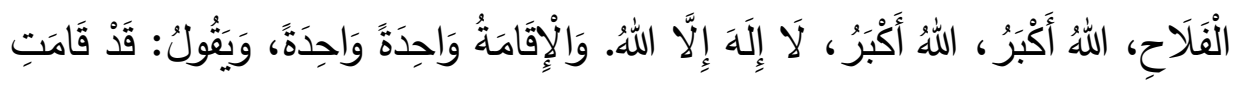

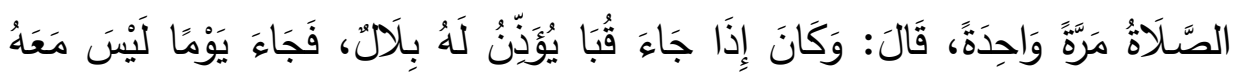

(1) القرظ: حب معروف يخرج في غُلْفٍ كالعدس من شجر العضاه، والقرظ شجر عظام لها

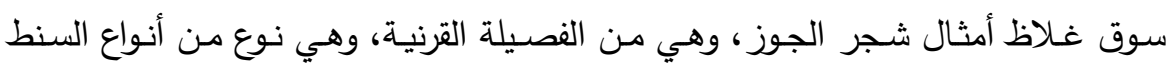

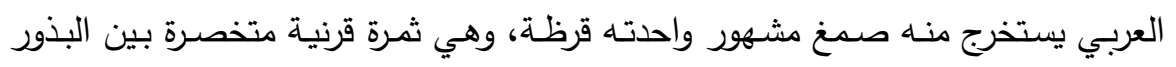

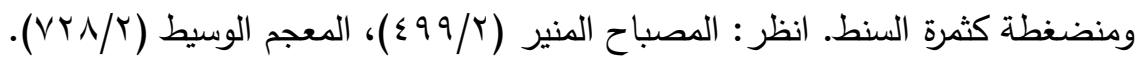




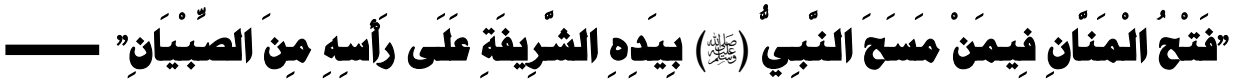

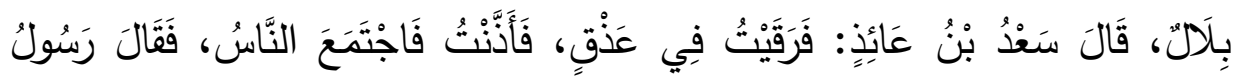

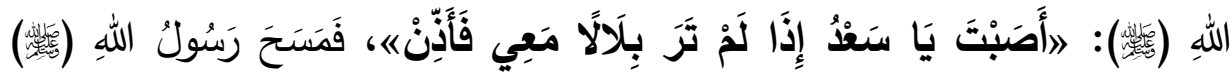

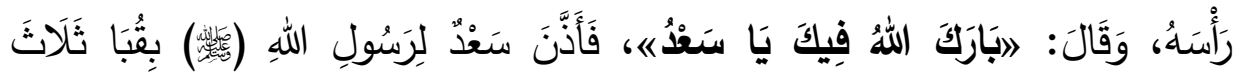

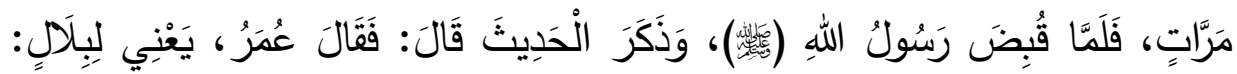

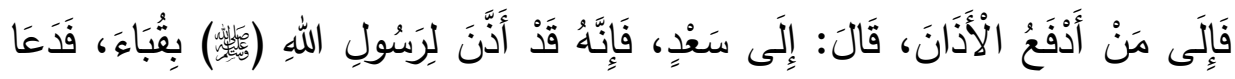

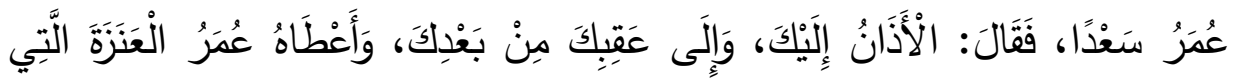

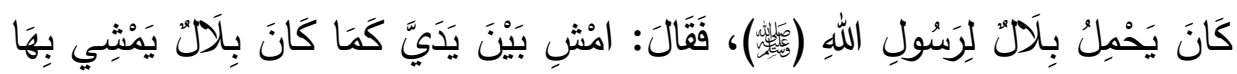

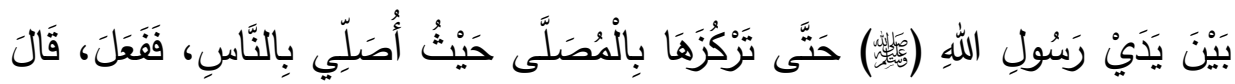

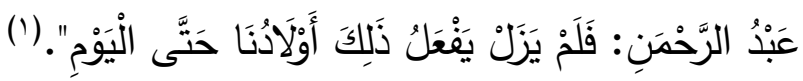

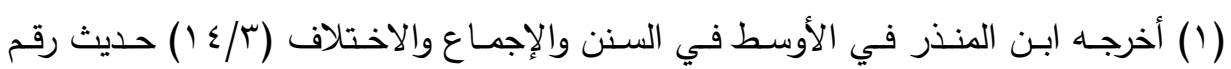

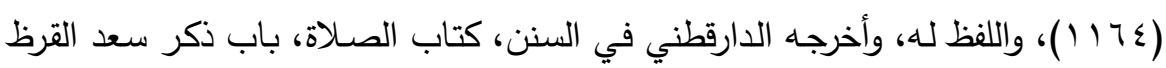

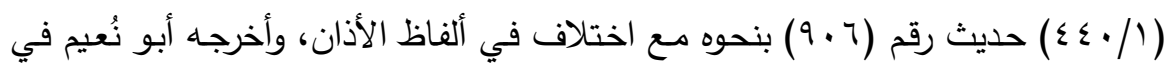

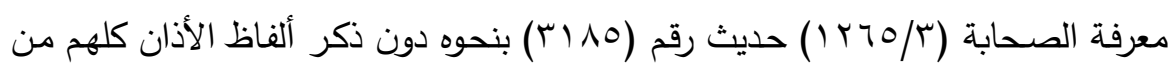

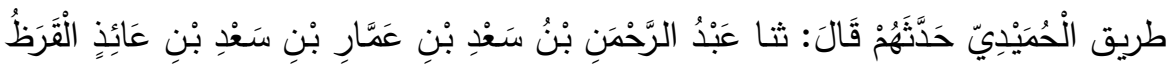

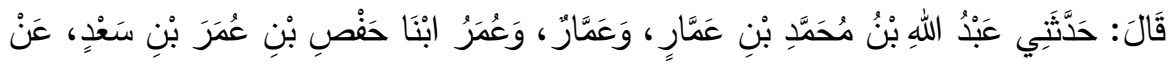

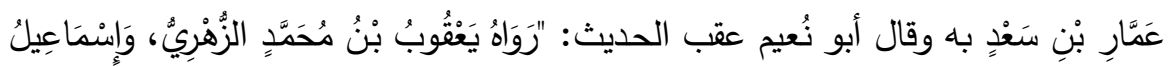

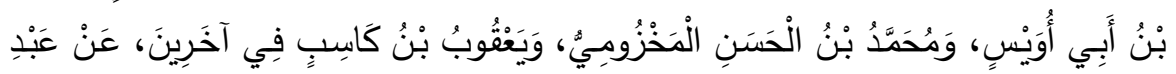

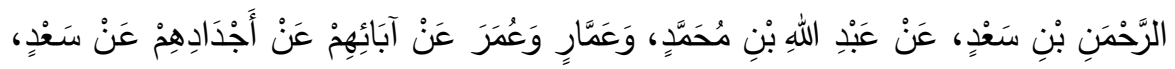

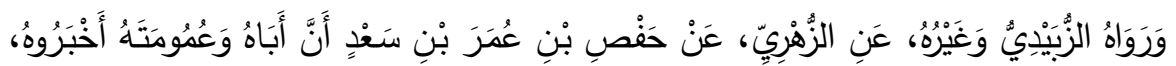

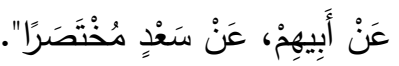

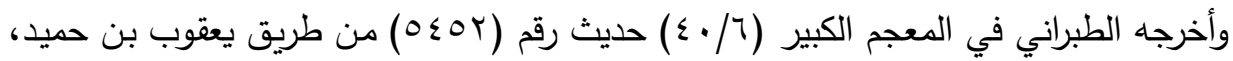

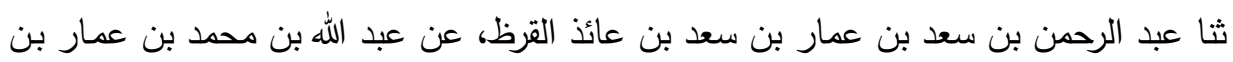

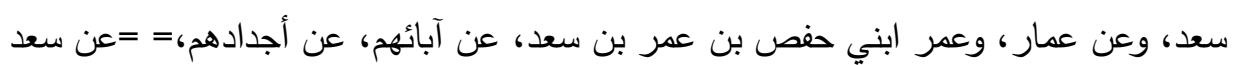

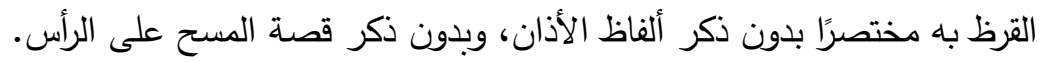




\section{مجلح كلية اصول الدين والدعوة بالموفية العدد التاسع والثلاثون}

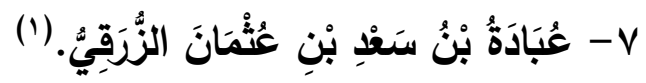

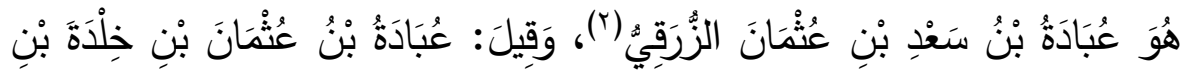

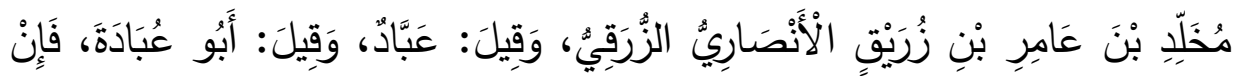

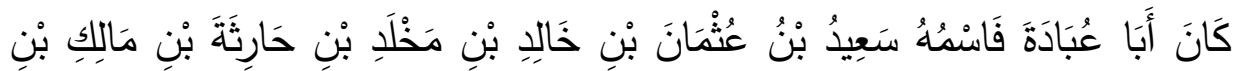
عَصَبِ بْنِ جُشَمِ بْنِ الْخَزْرَجِ بَدْرِيٌّ. قال موسى بن هارون: لله صحبة، ومن زعم أنه عبادة بن الصامت فقد وهم.

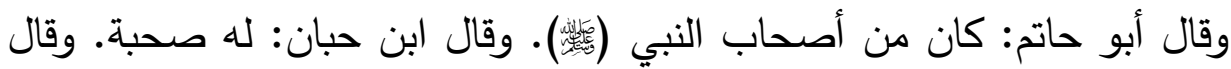
أبو عمر: لا ندفع صحبته. وقال ابن السكن: يقال: لله صحبة. روى عنه ابناه عبد الله، وسعد.

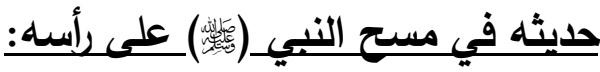

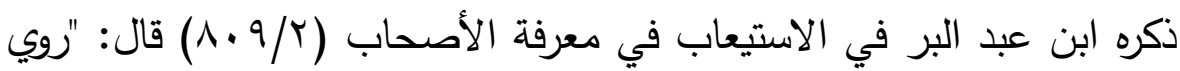

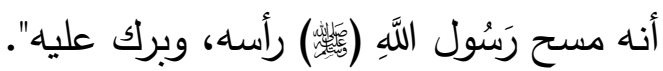
وذكره الحافظ ابن حجر في ترجمته في الإصابة في تمييز الصحابة

وهذا الحديث ضعيف؛ مداره على عبد الرحمن بن سعد القرظ، قال ابن معين: ضعيف، وقال

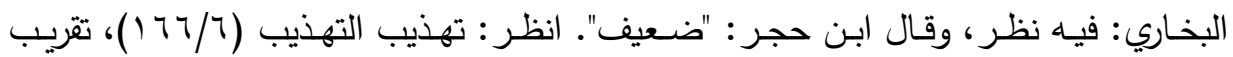

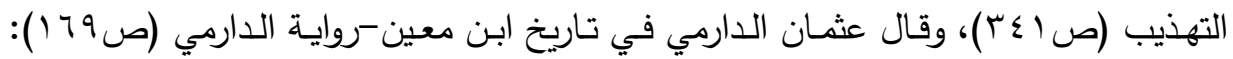

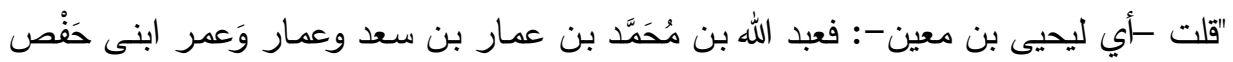

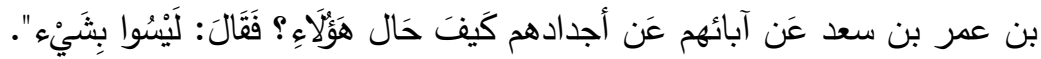

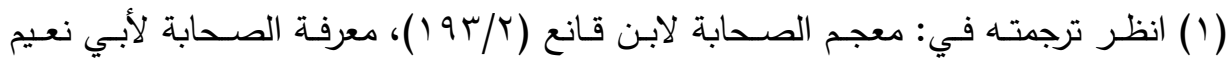

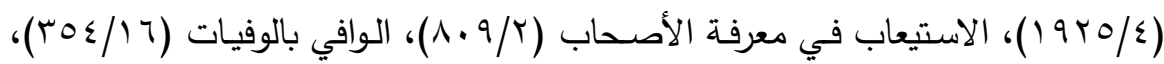

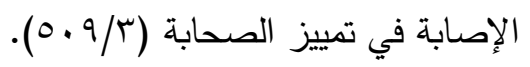

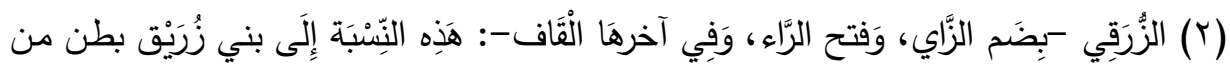

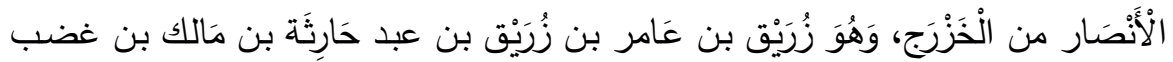

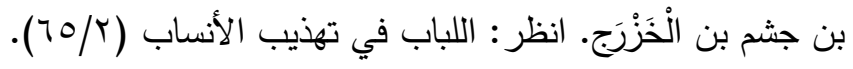




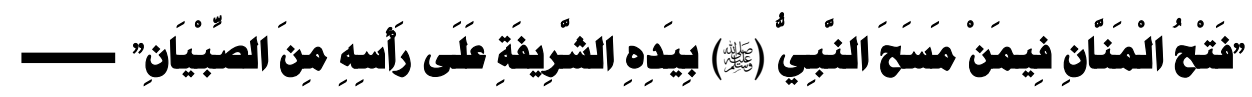

$$
\text { (T/\% • (0))، وعزاه إلى ابن سعد بدون إسناد. }
$$

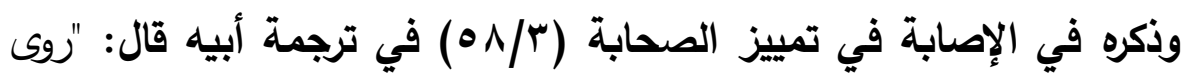

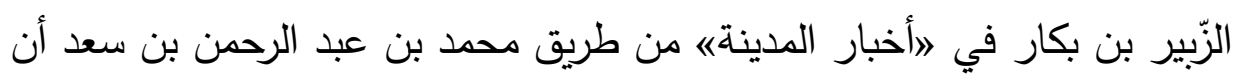

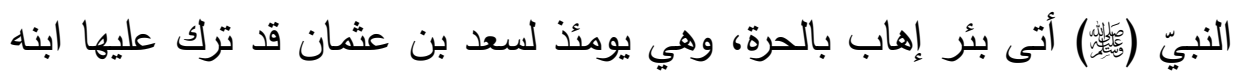

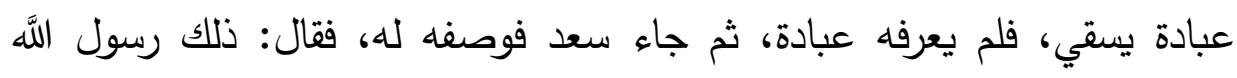

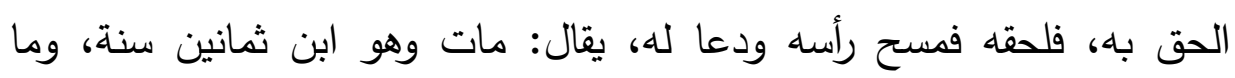
شاب".

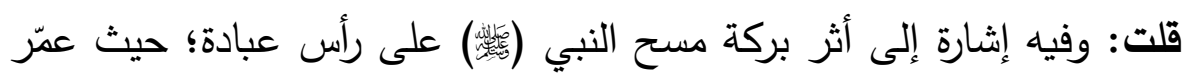

$$
\text { حتى الثمانين، وما شاب رأسه. }
$$

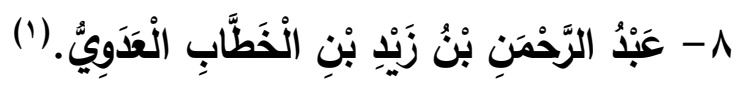

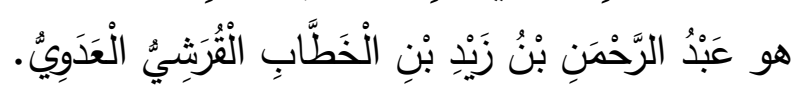
وأمه لُبابة بنت أبي لُبابة الأنصارية.

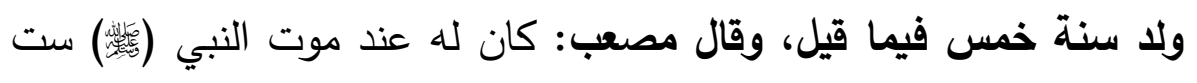

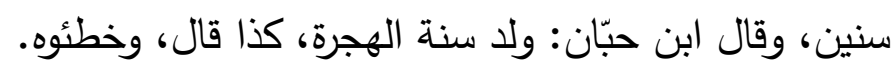
روى عن أبيه، وعمه، وابن مسعود، وغيرهم.

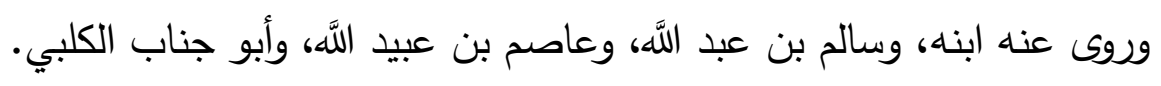

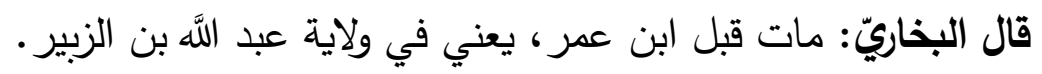

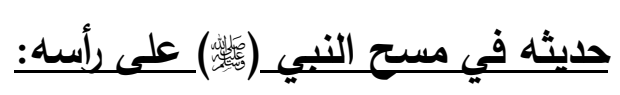
قال الزبير بن بكار : وحدثي ابراهيم بن محمد بن عبد العزيز الزهري، عن أبيه

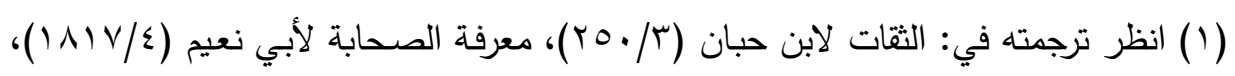

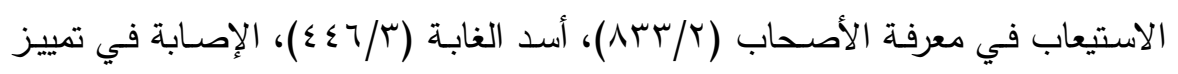

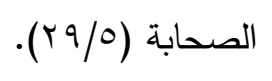




\section{مجلل كلية اصول الدين والدعوة بالموفية العدد التاسع والثلاثثون}

قال: ولد عبد الرحمن بن زيد بن الخطاب، وهو ألطف من ولد، فأخذه جده أبو

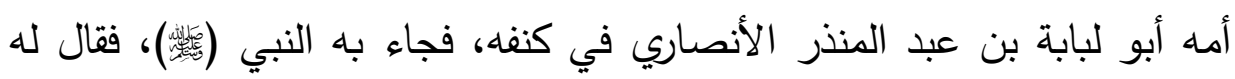

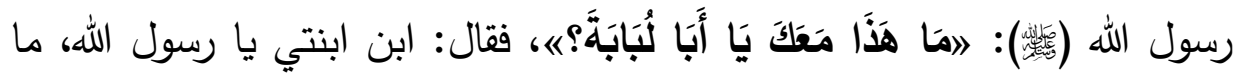

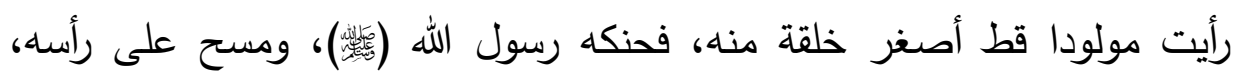
ودعا فيه بالبركة، قال: فما رئي عبد الرحمن بن زيد مع قوم في صف إلا نزعهم

(1) طولا.

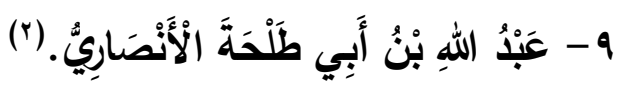

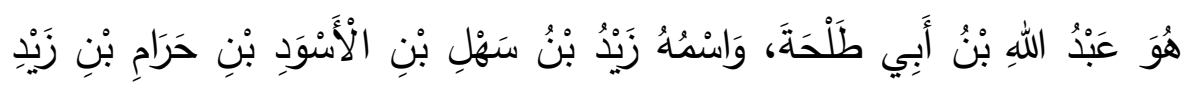

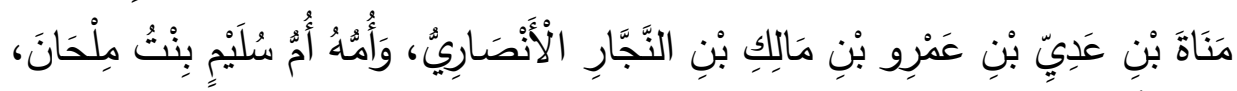

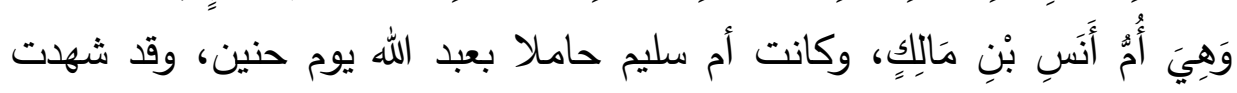
حنينا، ولم يزل عبد الله بالمدينة في دار أبي طلحة.

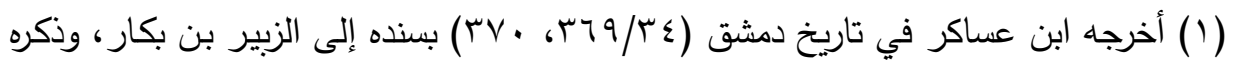

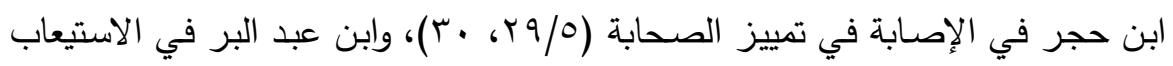

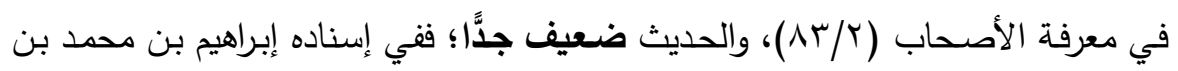

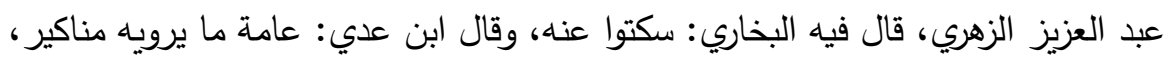

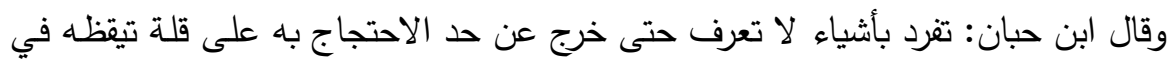

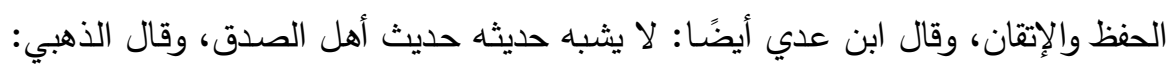

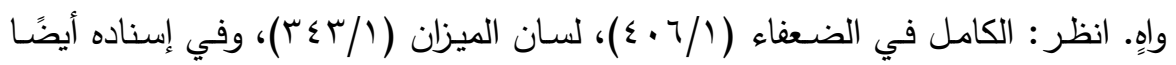

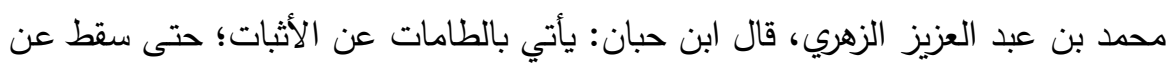

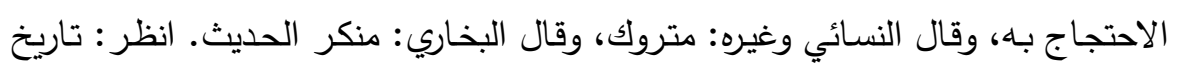

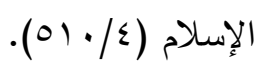

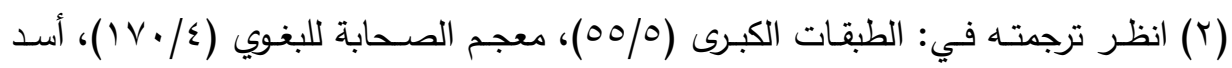

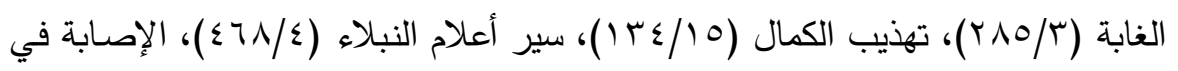

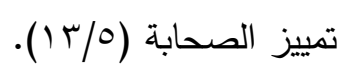




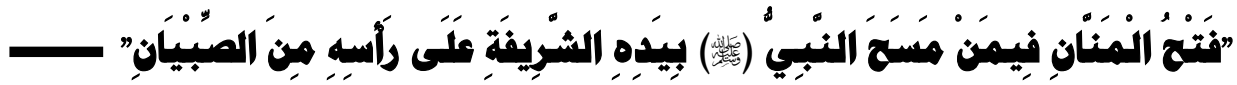

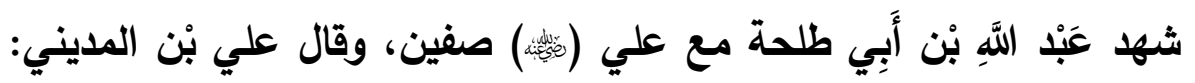

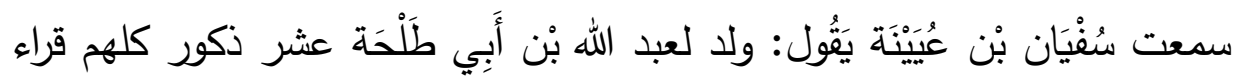
القرآن. روى عن أبيه أبي طلحة، وعن أخيه أنس بن مالكه، وروى عنه ابناه إسحاق

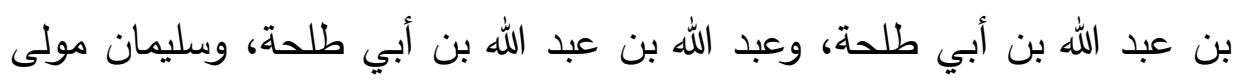
الحسن بن علي، وغيرهم.

هو قليل الحديث، ومات قبل أنس بمدة ليست بكثيرة، قال أبو نعيم الأصبهاني: استثهر بفارس. وقال غيره: مات بالمدينة سنة أربع وثمانين، وقيل:

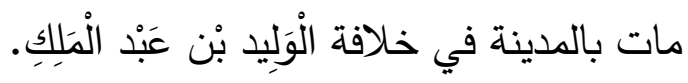

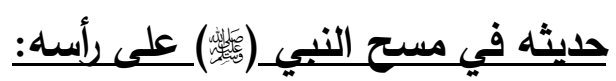

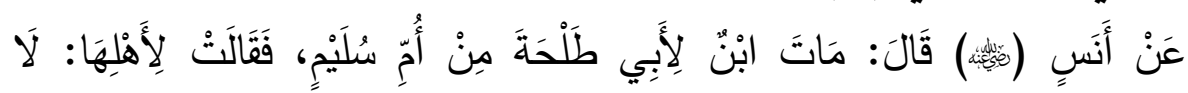

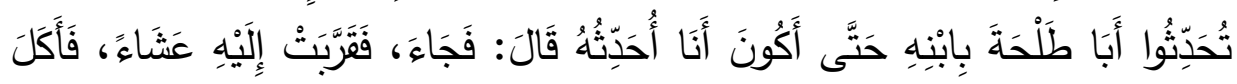

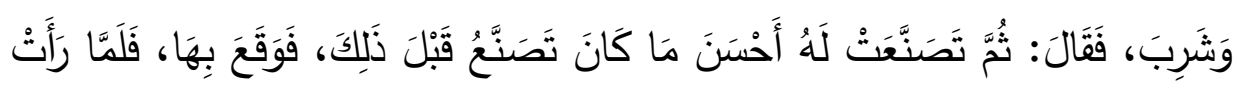

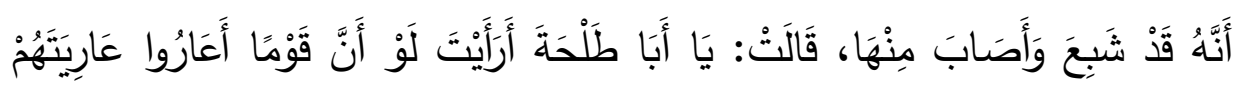

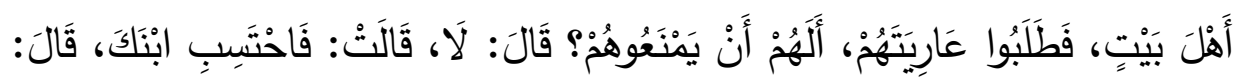

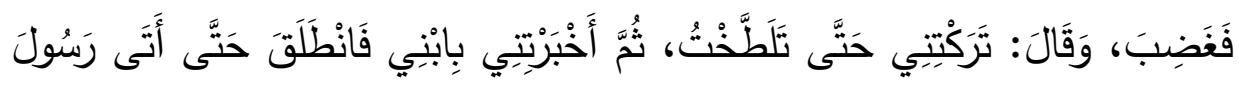

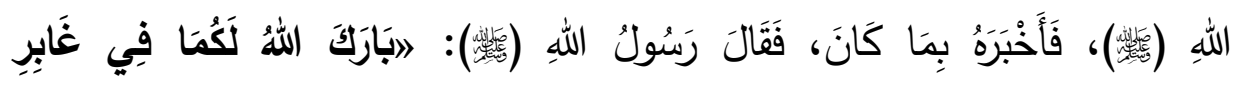

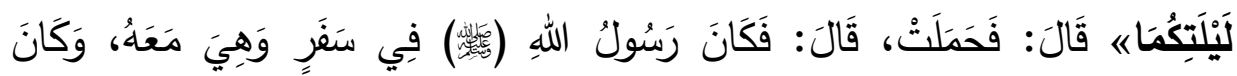

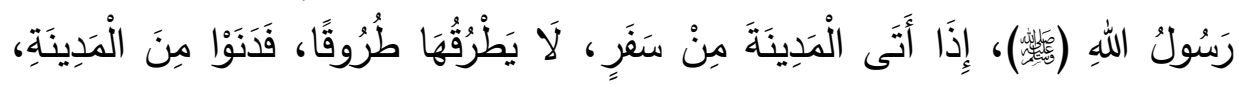

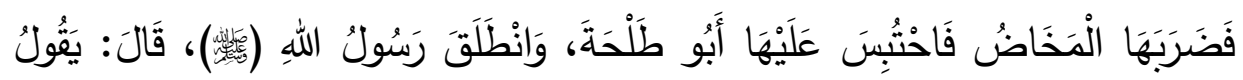

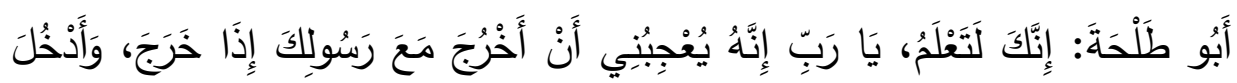

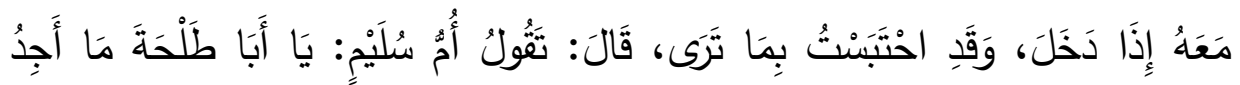




\section{مجلح كلية اصول الدين والدعوة بالمنوفية العدد التاسع والثلاثون}

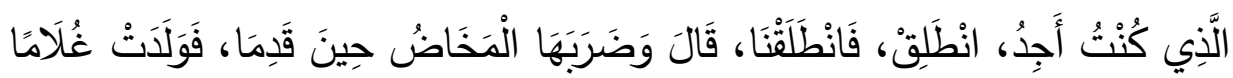

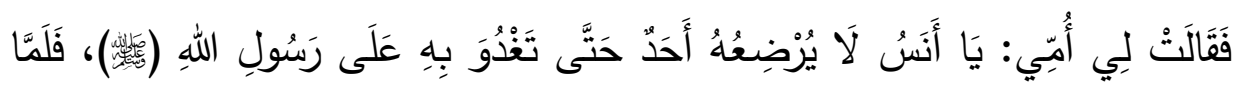

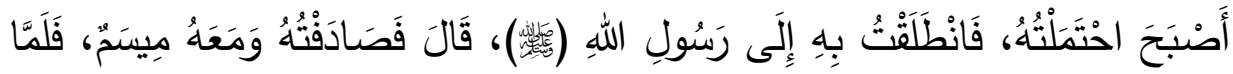

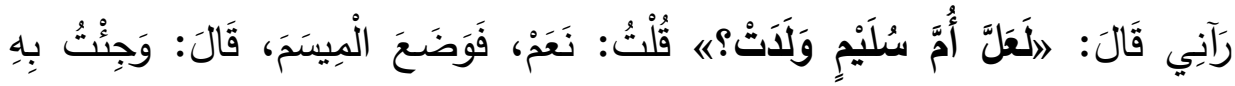

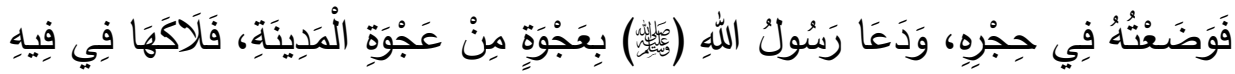

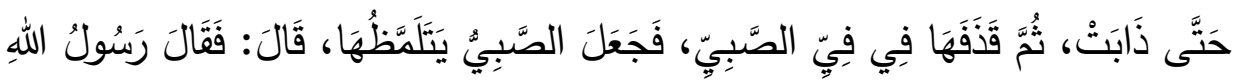

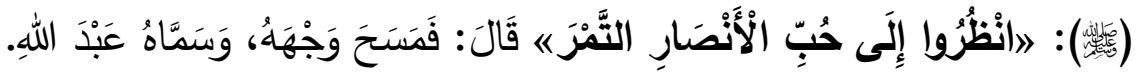

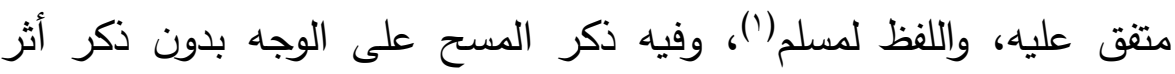
المسح. وفي رواية البيهتي في الدلائل أن الدسح كان على ناصيته، وفيها أيضًا بيان

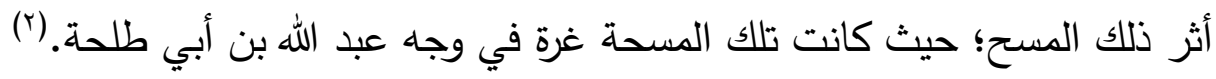

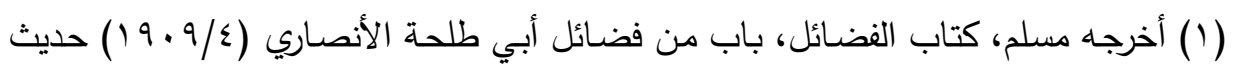

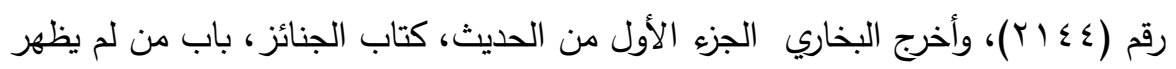

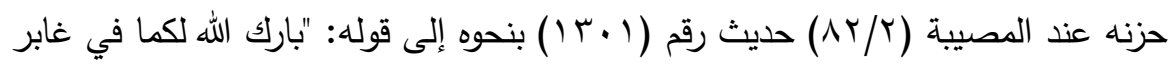

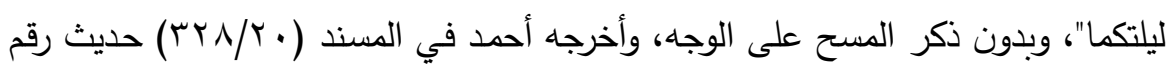

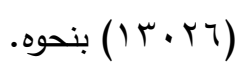

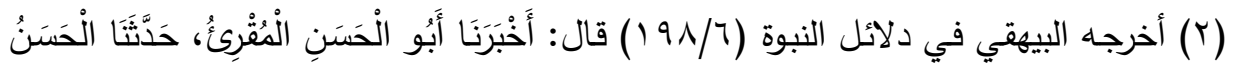

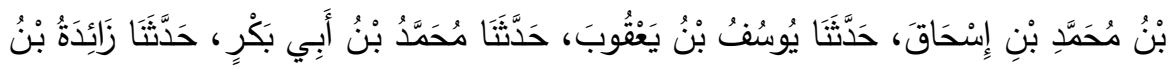

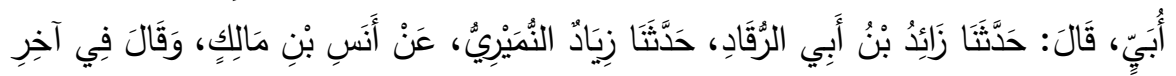

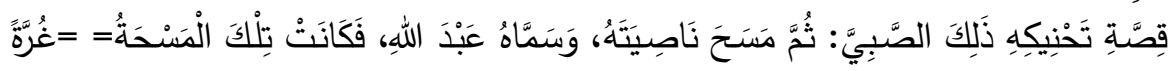
فِي وَجْهِهِ. والحديث بهذا الإسناد ضعيف؛ فيه زياد بن عبد الله النميري، ذكره ابن حبان في الثقات، وقال:

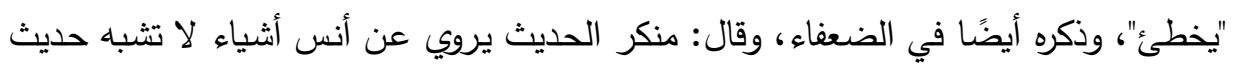

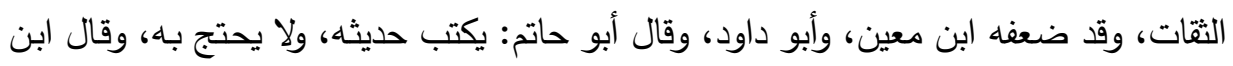




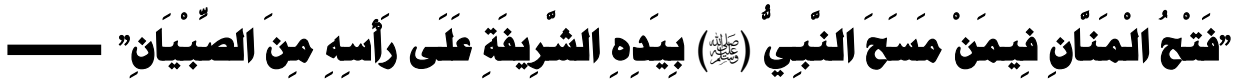

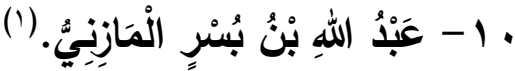

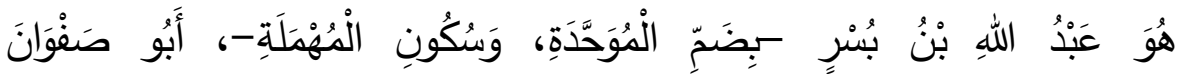

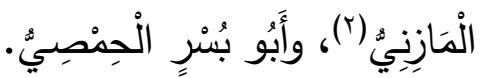

وهو آخر من مات بالثام من الصحابة، وصلى التبلتين.

له صحبة، ولأبويه وأخويها: عطية، والصماء.

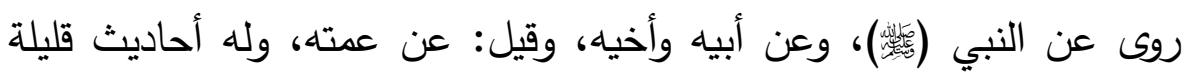

وصحبة يسيرة، وقد غزا جزيرة قبرس مع معاوية في دولة عثمان.

توفي سنة ست وتسعين في خلافة سليمان، وقيل: سنة ثمان وثمانين، وله دئه

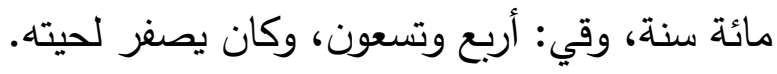

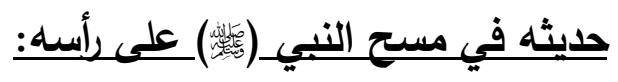

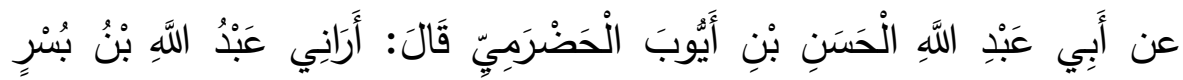

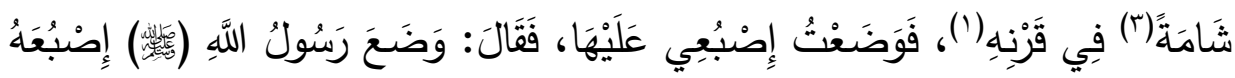

حجر : ضعيف. انظر : تهذيب التهذيب (rV^/T)، تقريب التهذيب (ص • (Y).

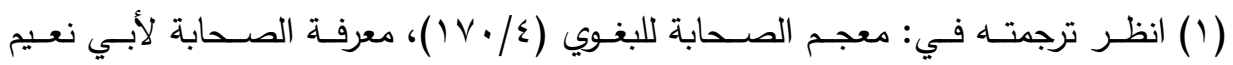

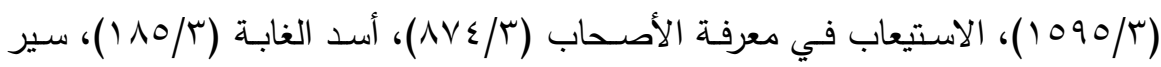

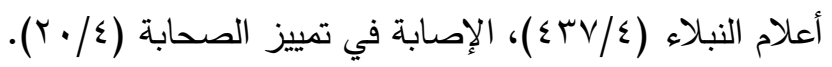

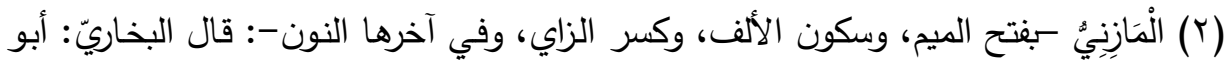

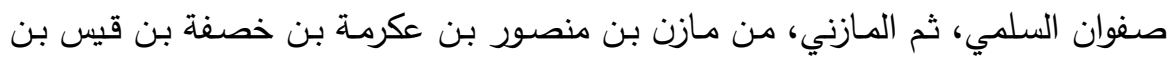

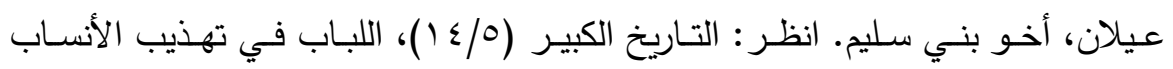
. (1 $\leqslant 0 / r)$

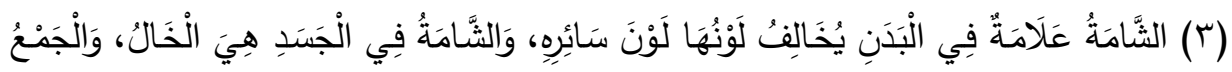

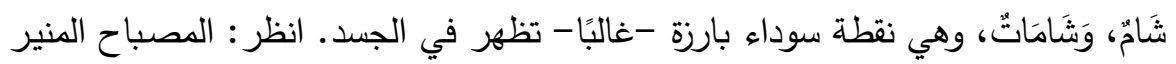

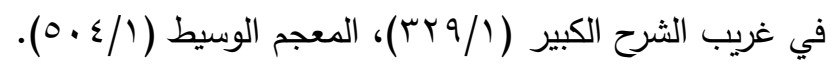




\section{مجلل كلية اصول الدين والدعوة بالموفية العدد التاسع والثلاثثون}

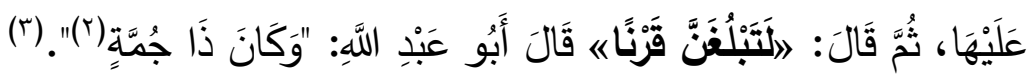

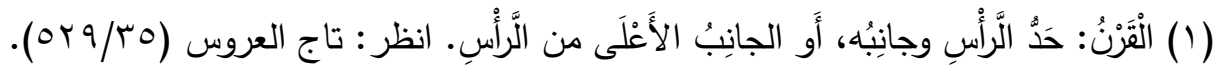

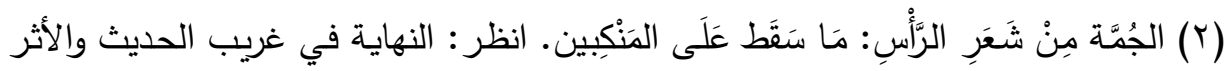

$$
\text { . (r. / / ) }
$$

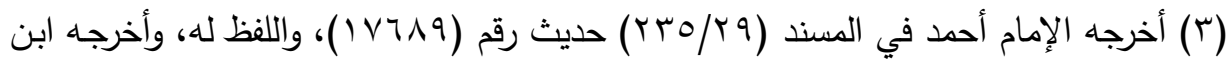

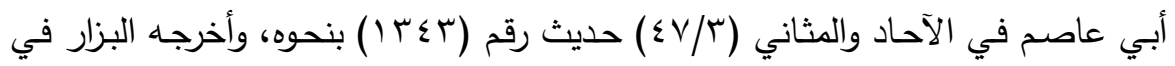

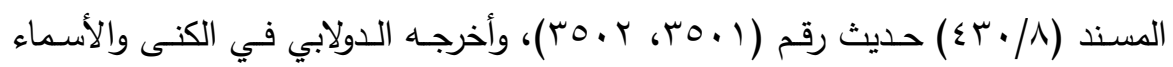

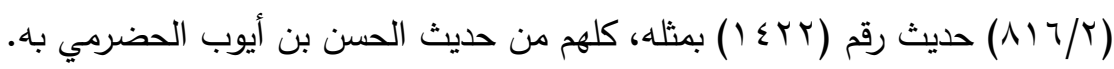

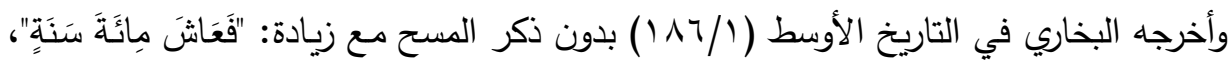

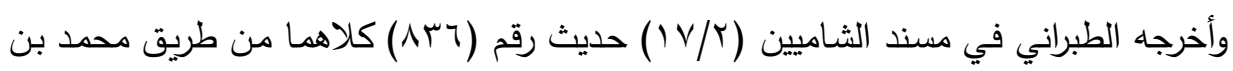

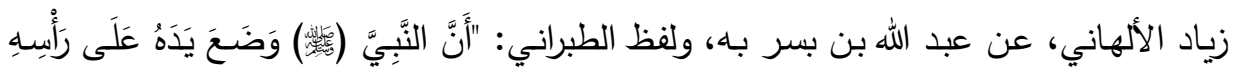

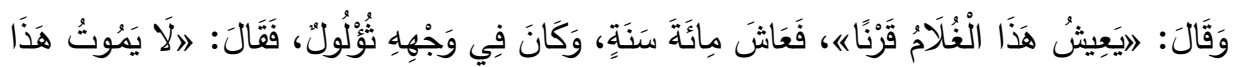

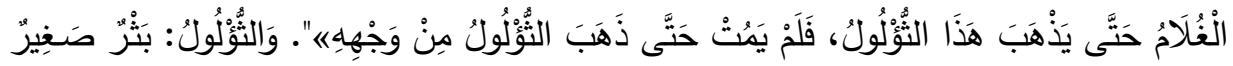

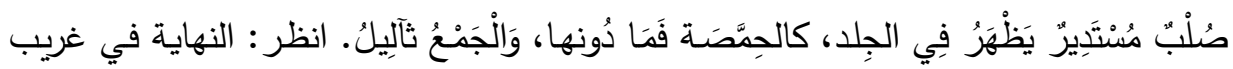

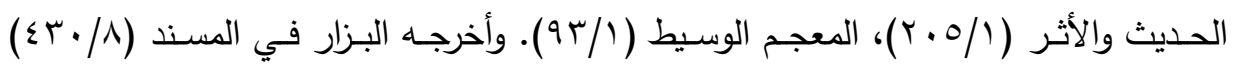

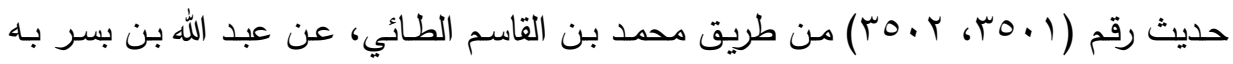

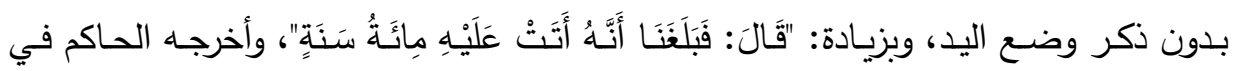
المستدرك، كتاب الفتن والملاحم (§/0؟0) من طريق محمد القاسمي الحمصي، عن عبد الله

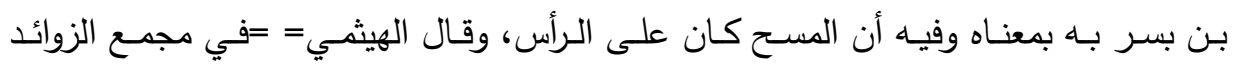

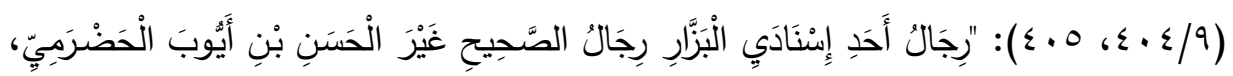
وَهْهُو بِقَقَّة".

والحديث صحيح لغيره؛ فرجاله ثقات غير الحسن بن أيوب بن عبد الله الحضرمي، قال أحمد:

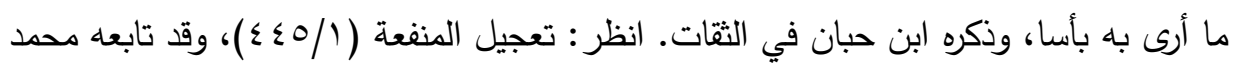

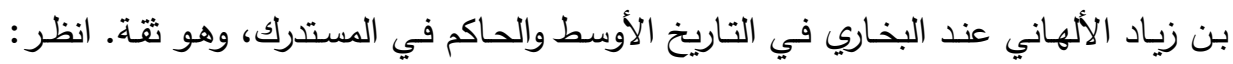

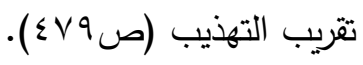




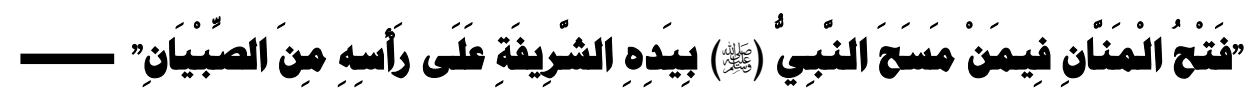

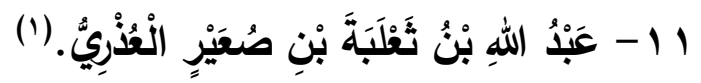

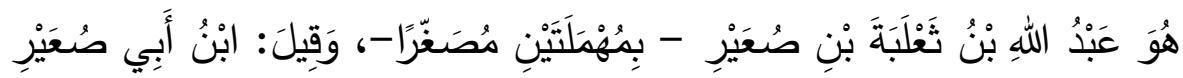

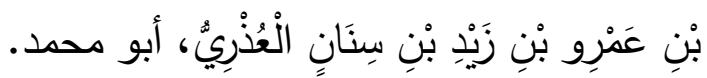

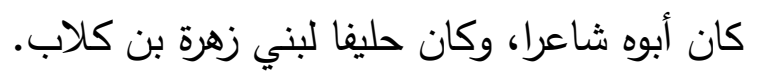

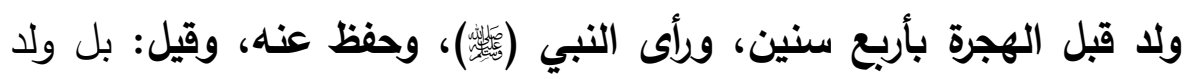
عام الفتح، وقد شهد الجابية، فلو كان مولده عام الفتح لصبا عن شهود الجابية.

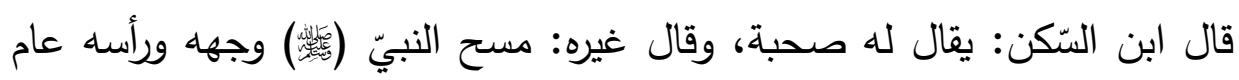

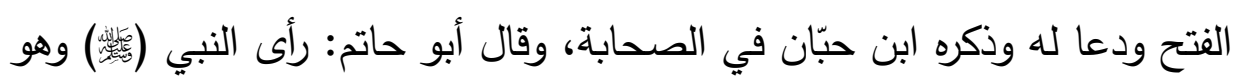
• - nغير

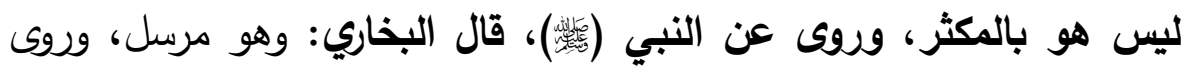

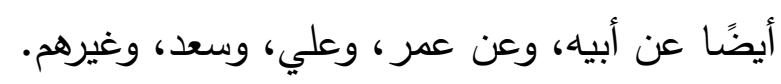

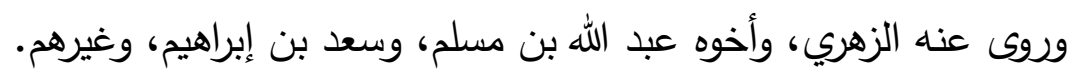

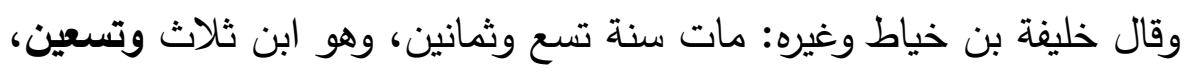
وقيل: سنة سبع وثمانين، وهو ابن ثلاث وثمانين.

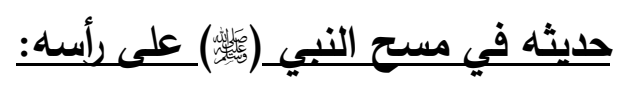

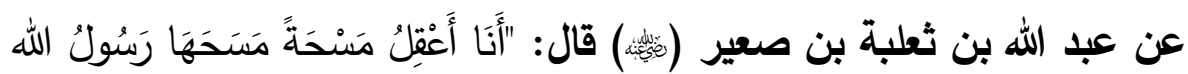

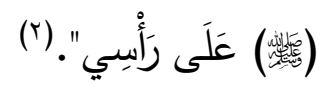

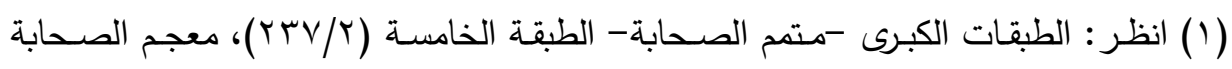

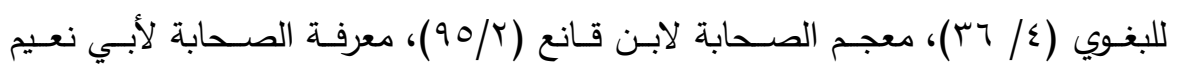

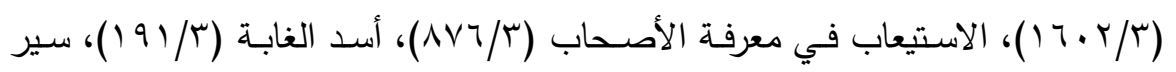

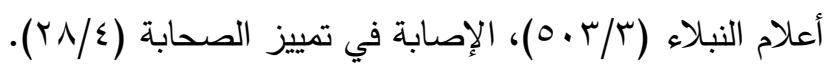

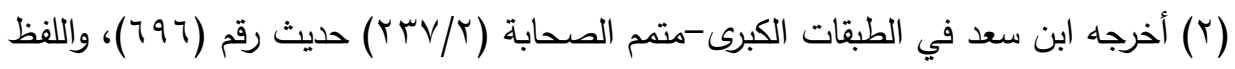

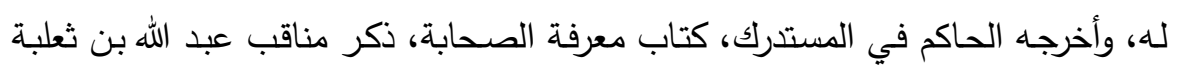




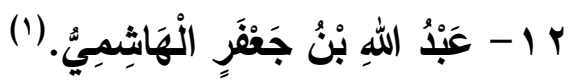

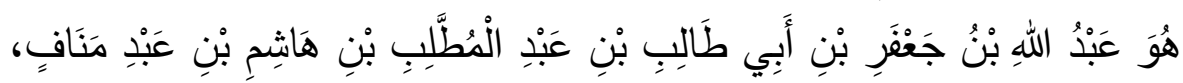
وَيُكْنَى أَبَا جَعْفَرِ

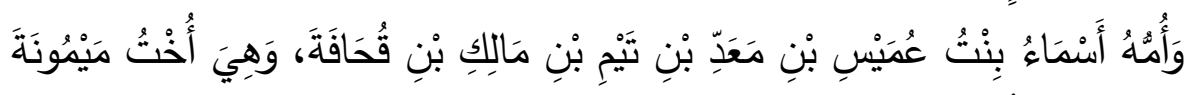

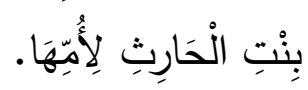

هو أول مولود ولد في الإسلام بأرض الحبشة، وقدم مع أبيه المدينة، وحفظ

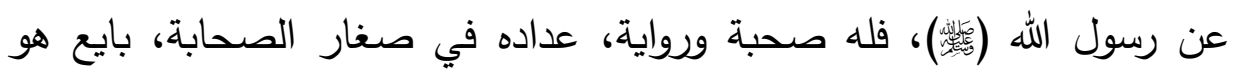
وعبد الله بن الزبير رسول الله (或)، وهو ابن سبع سنين.

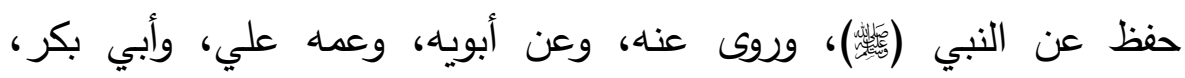
وعثمان، وعمار بن ياسر • وروى عنه بنوه: إسماعيل، وإسحاق، ومعاوية، وأبو جعفر الباقر، والثعبي،

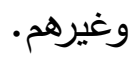

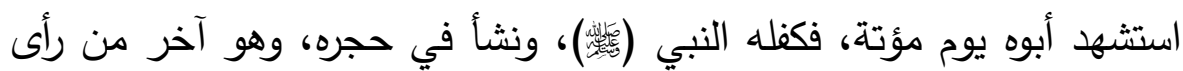

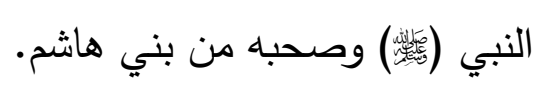

اختلف في سنة وفاته، والأرجح أنه مات سنة ثمانين عام الْجِحَافِ، وهو سيل

بنحوه، كلاهما من طريق الزهري، عن عبد الله بن ثعلبة به، وأصل الحديث في الصحيح،

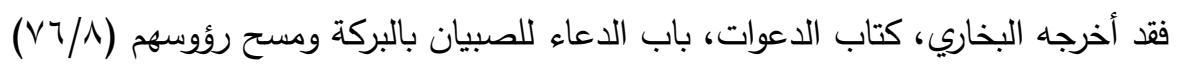

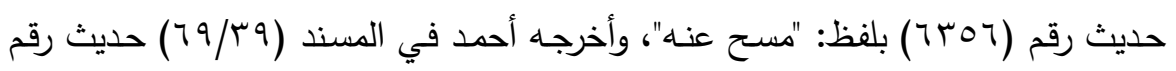

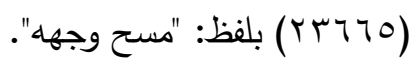

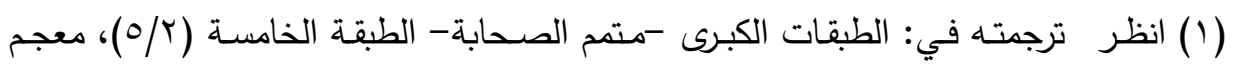

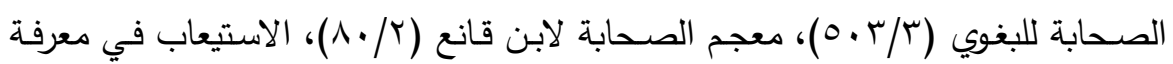

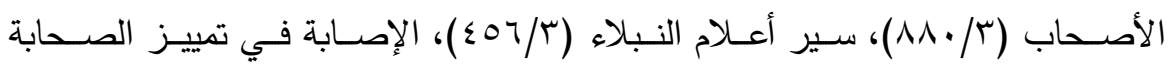
. $(r \circ / \varepsilon)$ 


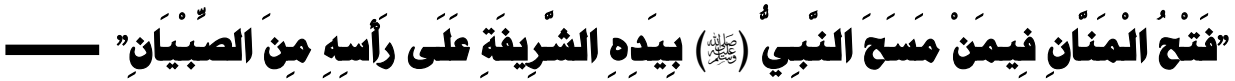

كان ببطن مكة جحف الحاجّ، وذهب بالإبل، وعليها الحمولة، وصلى عليه أبان

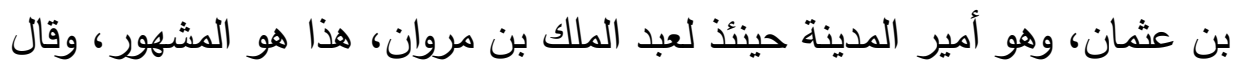
الواقديّ: مات سنة تسعين، وكان له يوم مات تسعون سنة. قال ابن عبد البر: والأول أولى عندي، وعليه أكثرهم أنه توفي سنة ثمانين،

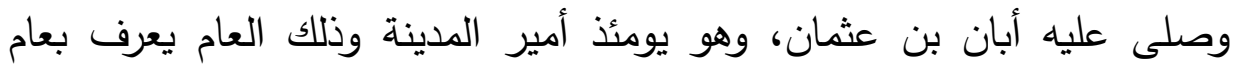
الجحاف لسيل كُانَ بمكة أجحف بالحاج، وذهب بالإبل، وعليها الحمولة.

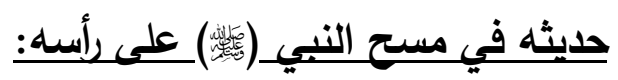

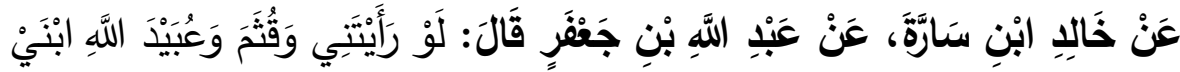

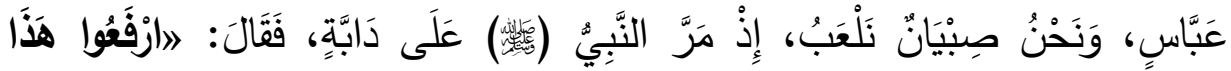

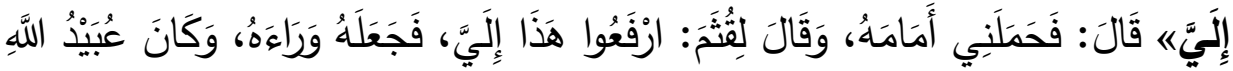

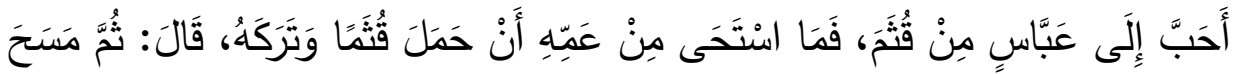

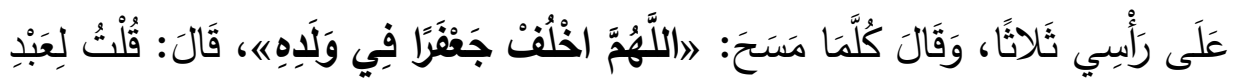

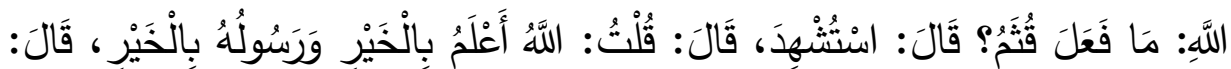
(') أَجَلْ

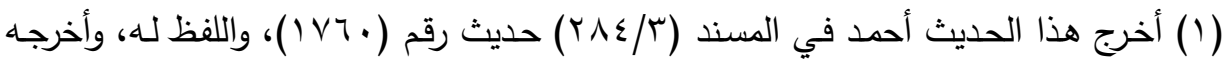

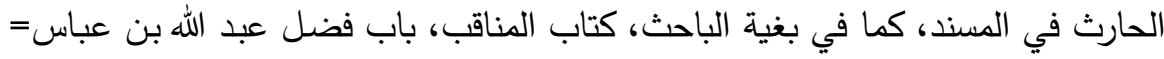

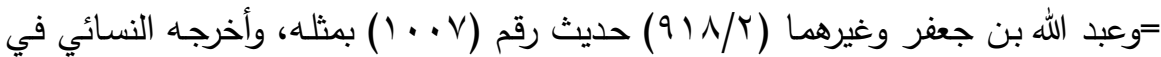

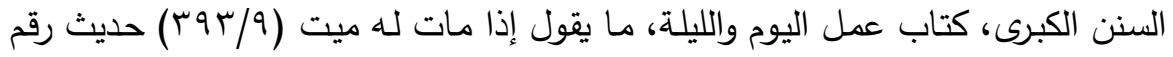

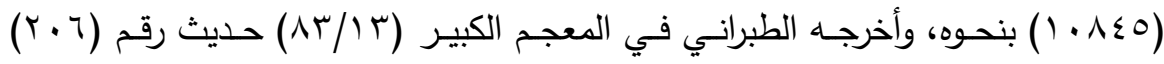

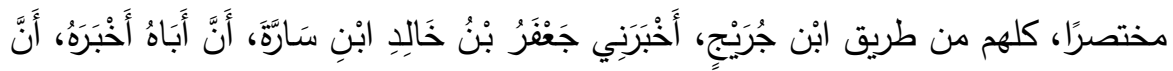

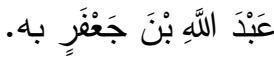

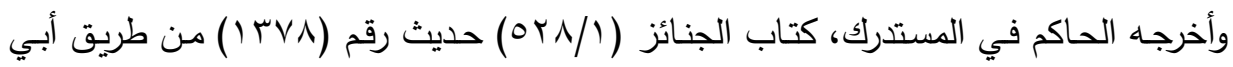

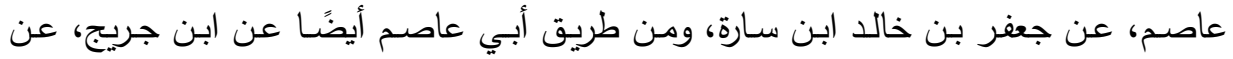




\section{مجلل كلية أصول الدين والدعوة بالمنوفية العدد التاسع والثلاثون}

با

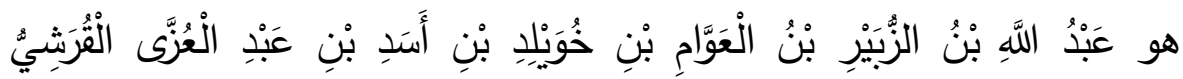
الْأَسَدْديُّ. أمّه أسماء بنت أبي بكر الصديق. ولا عام الهجرة، وحفظ عن النبيّ (赔) وهو صغير، وحدّث عنه بجملة من الحديث، وعن أبيه، وعن أبي بكر، وعمر، وعثمان، وخالته عائشة، وسفيان بن وهئ وهئ وهن أبي زهير وغيرهم. وروى عنه أخوه عروة، وابناه: عامر، وعباد، وابن أخيه محمد بن عروة، وعمرو بن دينار ، وغيرهم. وهو أحد العبادلة، وأحد الثجعان من الصحابة، وأحد من ولى الخلافة منهم. يكنى أبا بكر، وبويع بالخلافة سنة أربع وستين عتب موت يزيد بن معاوية، ولم

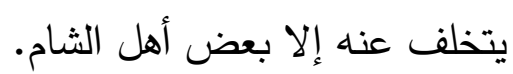
قتل في جمادى الأولى سنة ثلاث وسبعين من الهجرة، هذا هو المحفوظ، وهو

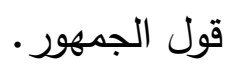

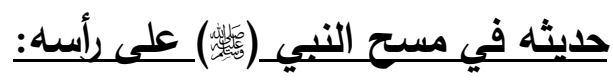

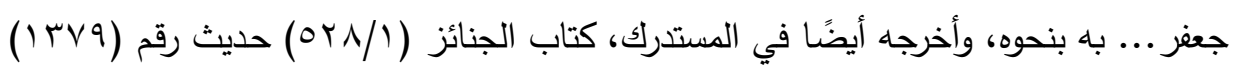
من حديث الحارث بن أبي أسامة، عن روح بن عبادة.... به مختصرًا.

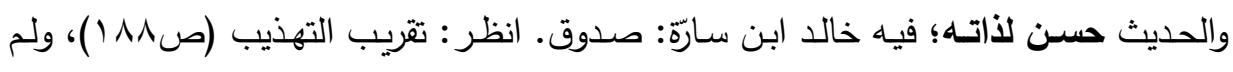
يتابع، وبقية رجاله ثقات، وقد قوّى الحافظ ابن حجر إسناد الحديث في الإصابة في تمييز

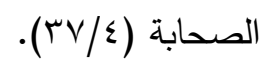

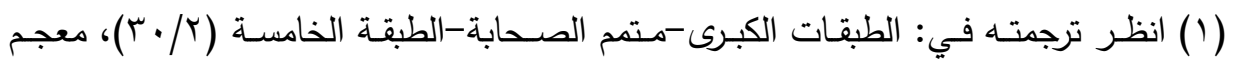

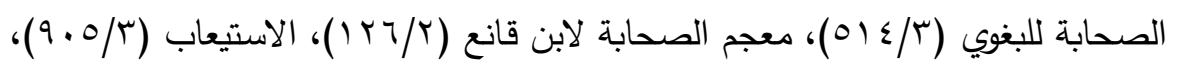

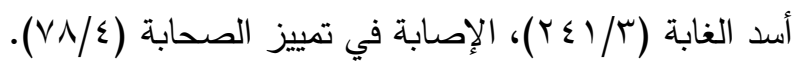




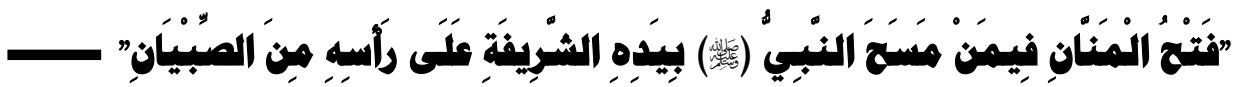

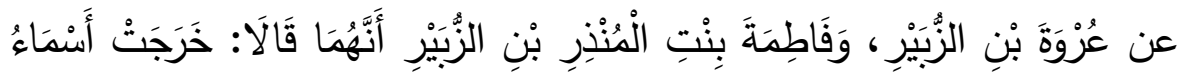

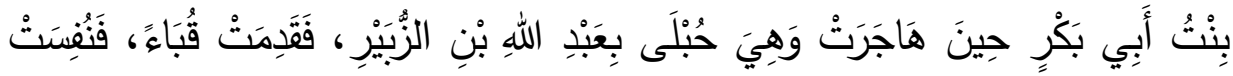

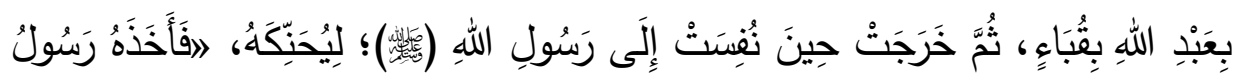

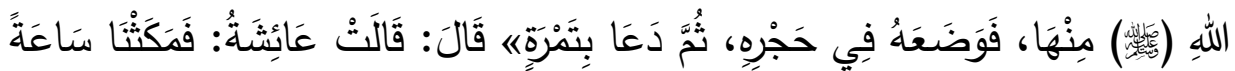

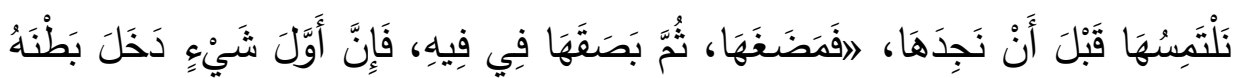

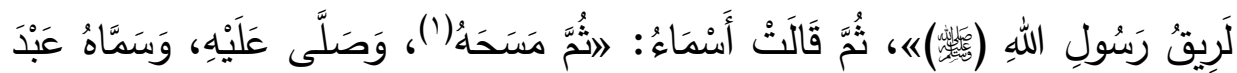

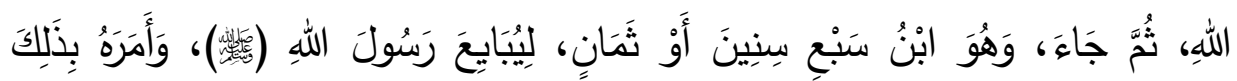

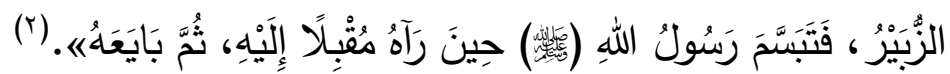
قال النووي: "وفى هذا الحديث مع ما سبق شرحه مناقب كثيرة لعبد الله بن

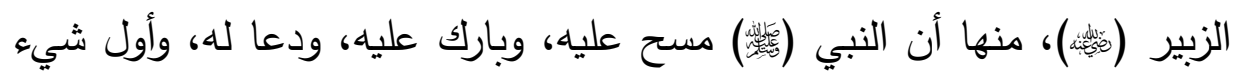

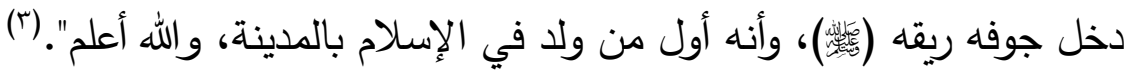

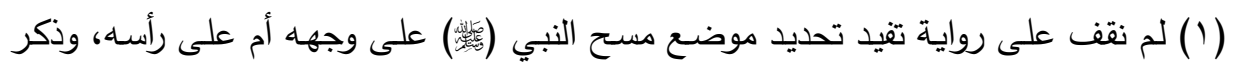

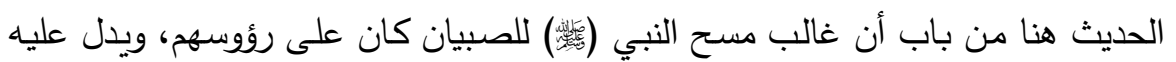

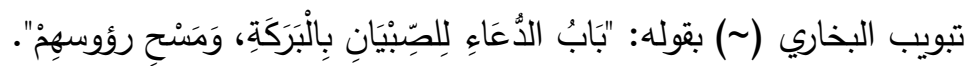

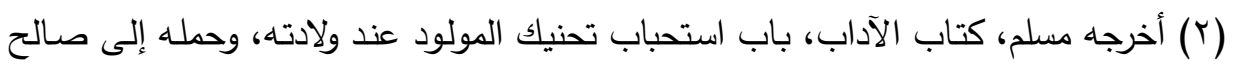

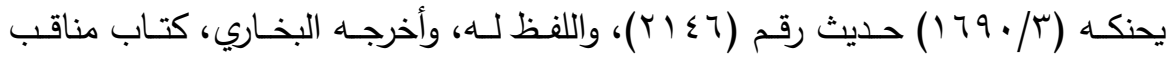

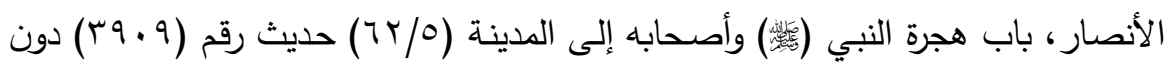
ذكر المسح.

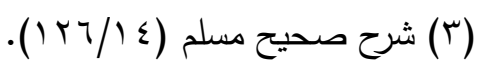




\section{مجلح كليح اصول الدين والدعوة بالمنوفية العدد التاسع والثلاثثون}

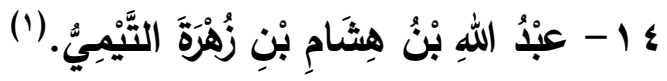

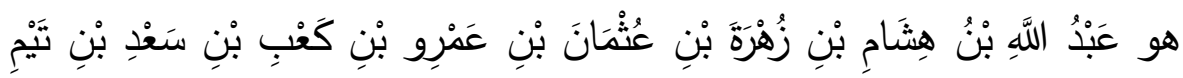

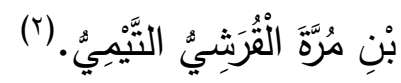

له ولأبيه صحبة، وأمه زينب بنت حميد بن زهير بن الحارث بن أسد بن عبد العزى بن قصي. وقال ابن مندة: كان مولده سنة أربع. وقال البغوي: سكن المدينة.

ذهبت به أمه إلى النبي (赔) وهو صغير ، فمسح رأسه، ودعا لله، ولم يبايعه

لصغره.

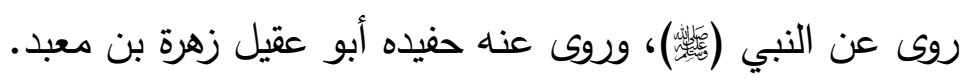

$$
\begin{aligned}
& \text { وذكر البلاذريّ أنه عاش إلى خلافة معاوية. } \\
& \text { حديثه في مستح النبي_(ئي }
\end{aligned}
$$

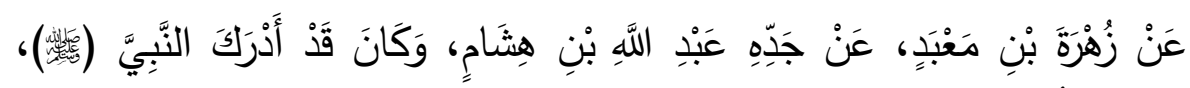

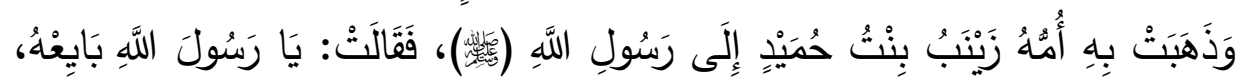

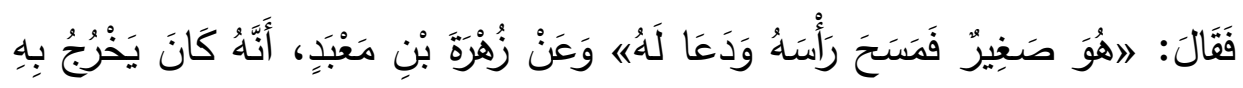

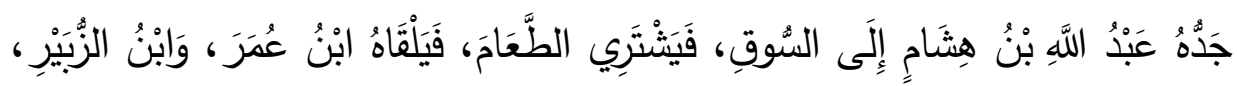

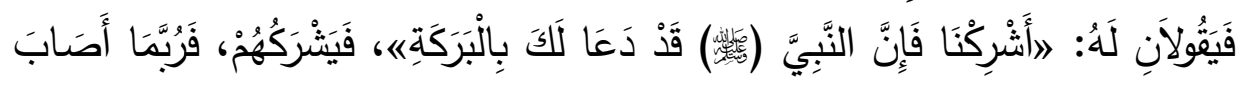

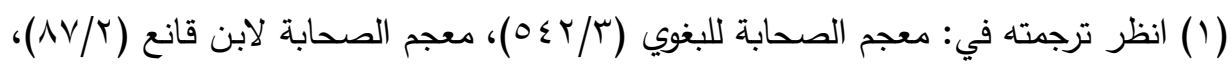

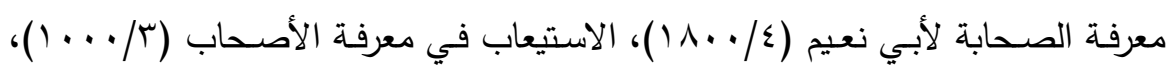

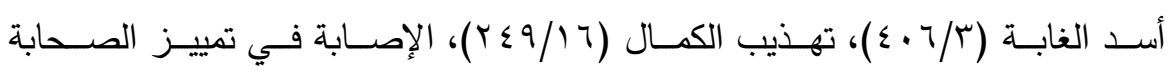
( $($ I $V / \varepsilon)$

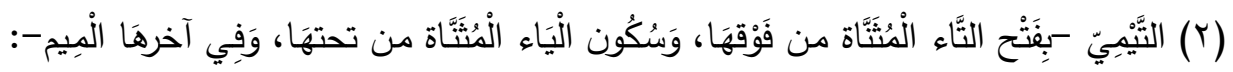

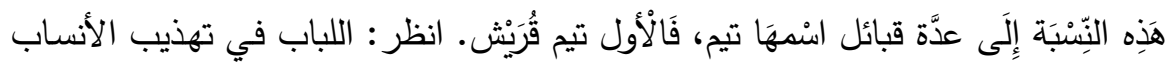




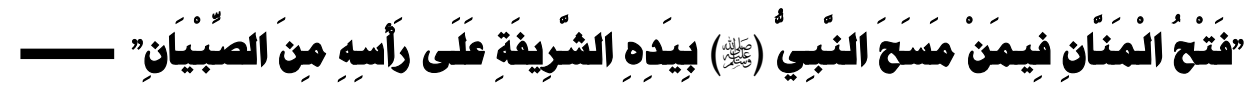

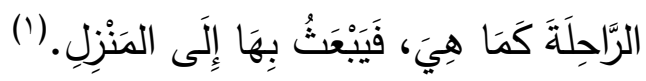

ه 10

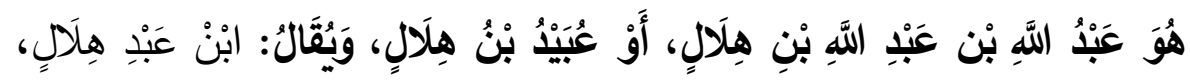

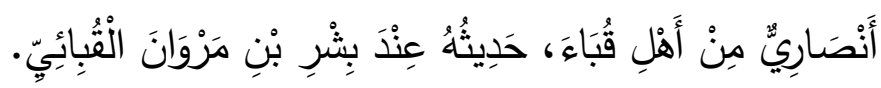

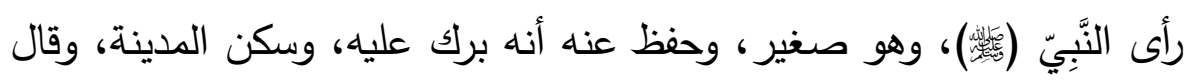

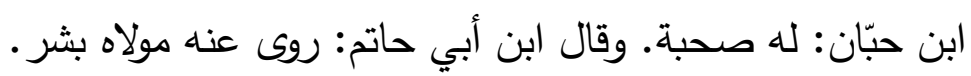

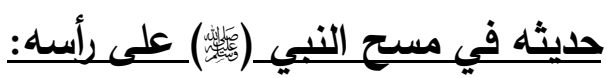

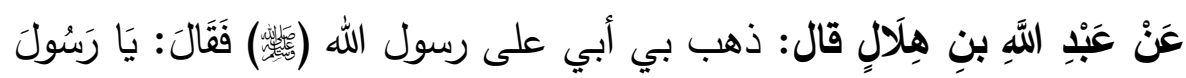

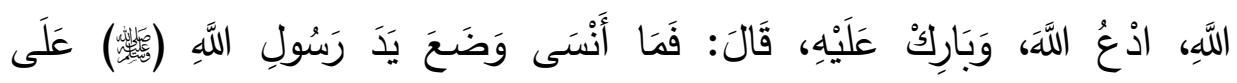

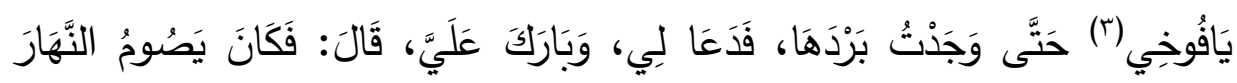

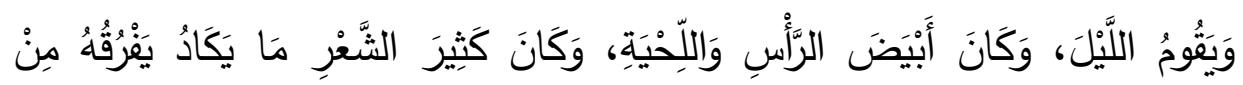

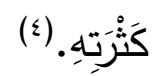

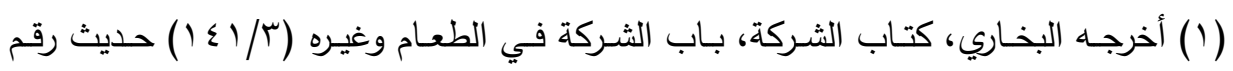

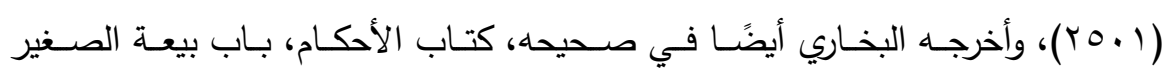

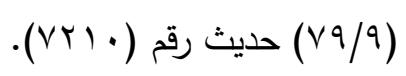

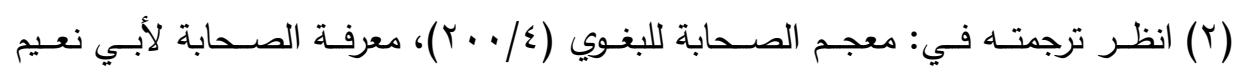

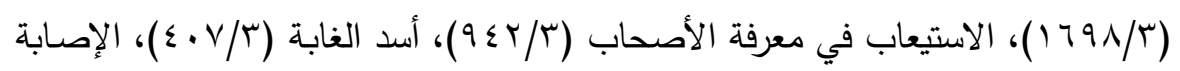

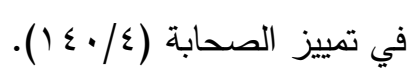

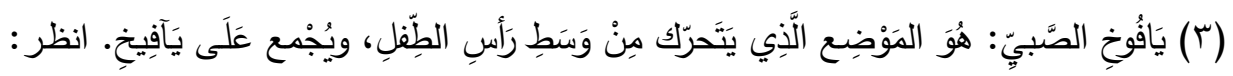

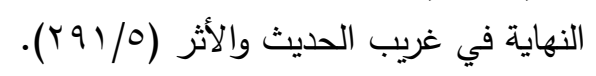

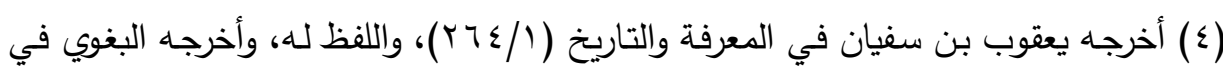

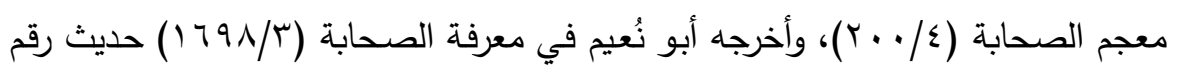

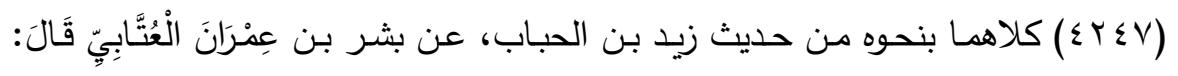


(1). 17

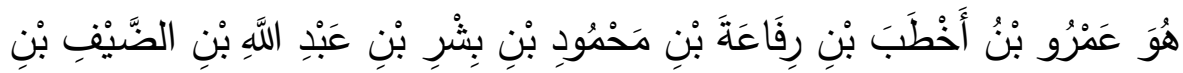

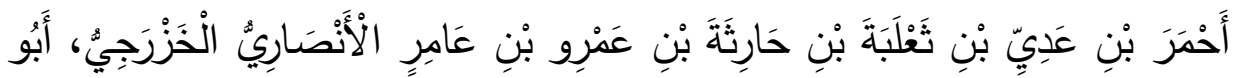

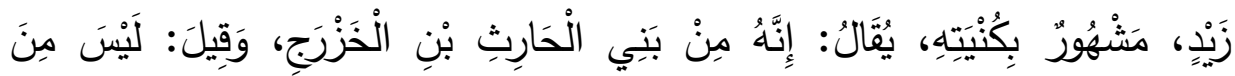

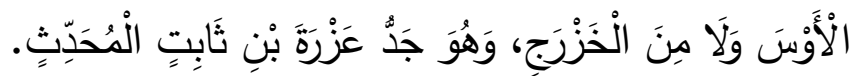

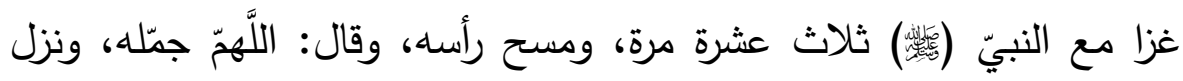

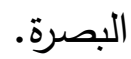

له صحبة ورواية عن النبي (赔)، وحديثه في صحيح مسلم، والسنن، وهو ممن جاوز المائة. وروى عنه ابنه بشير، وأنس بن سيرين، وأبو قلابة الجرمي، وآخرون.

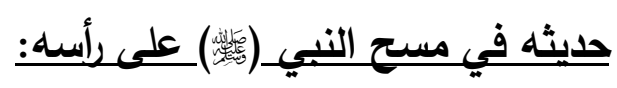

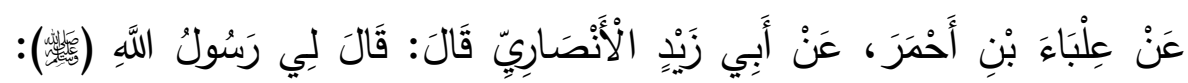

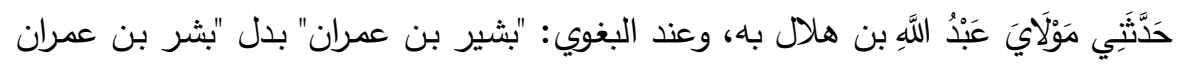

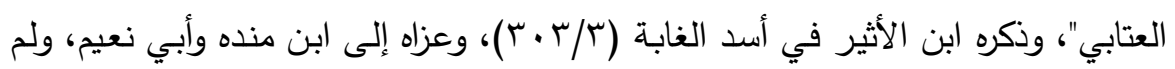
أقف عليه في المطبوع من معرفة الصحابة لابن منده. وهذا الحديث ضعيف؛ تفرّد به زيد بن الحباب، عن بشر بن عمران بن كيسان القبائي، وقيل:

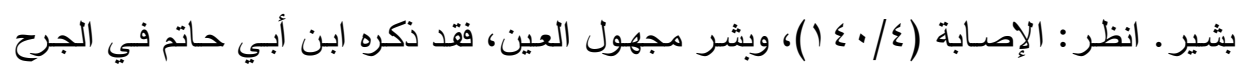

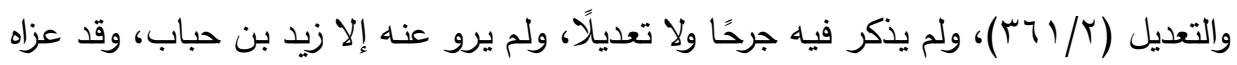

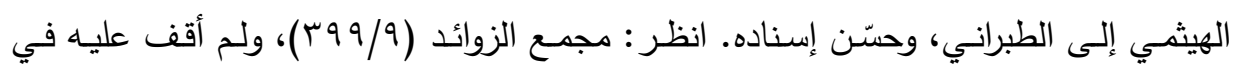
المطبوع من الطبراني.

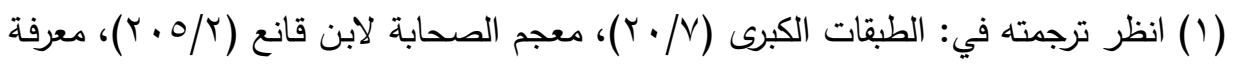

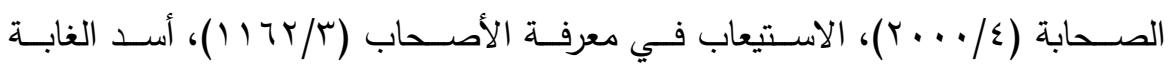
( ) (

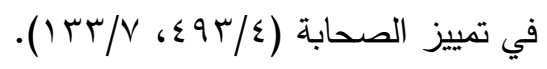




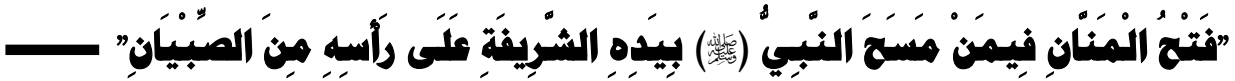

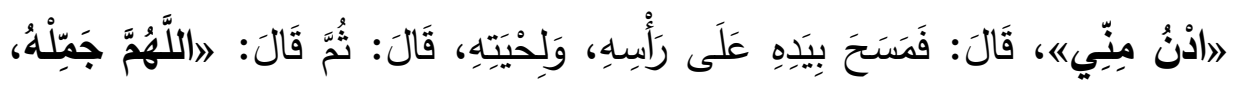

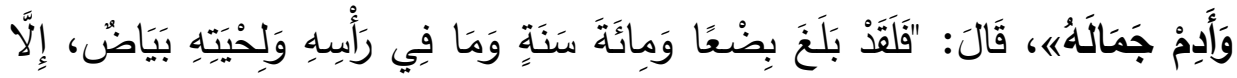

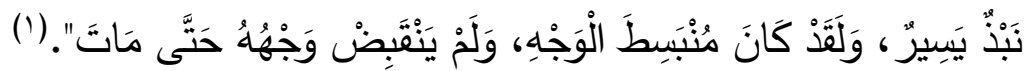

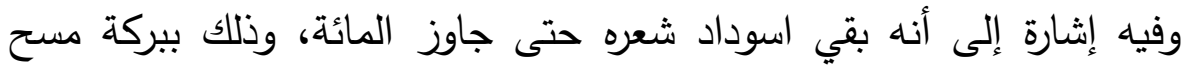

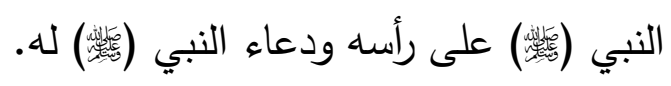

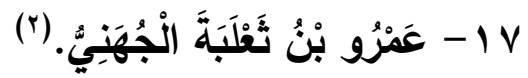

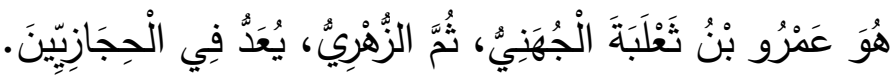

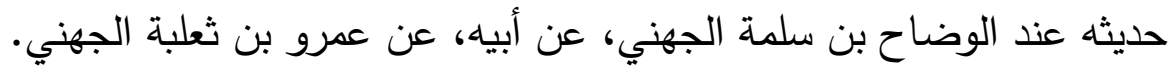

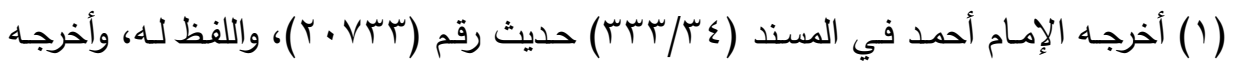

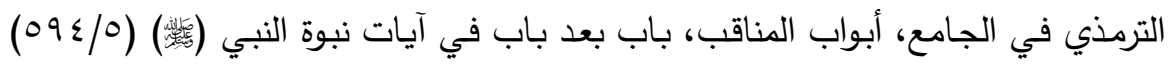

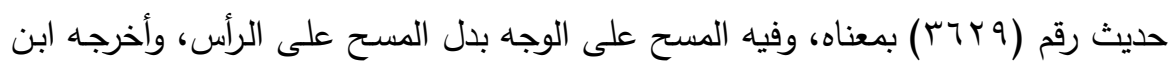

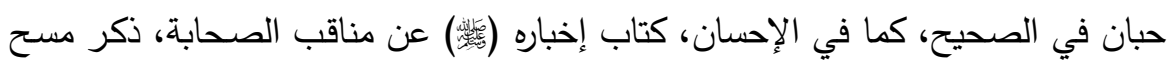

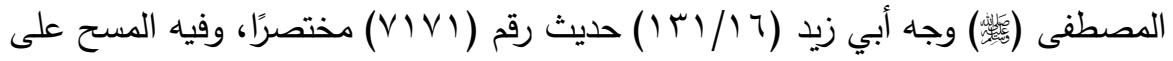

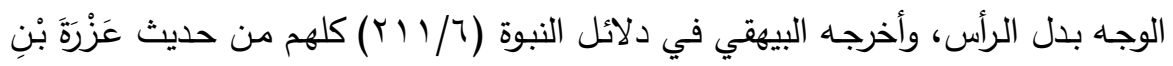

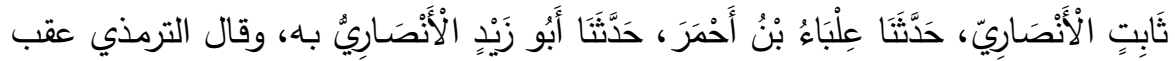

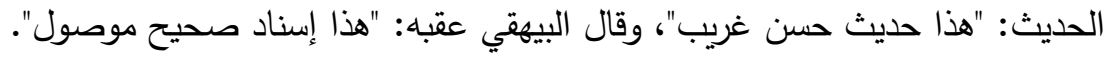

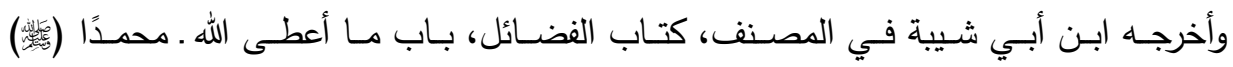

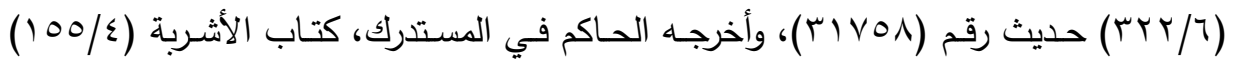

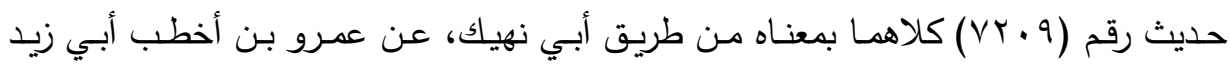

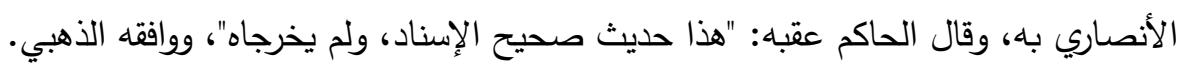

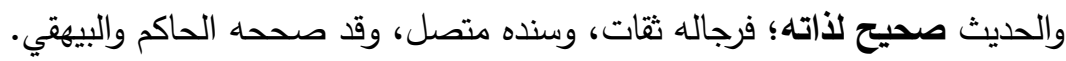

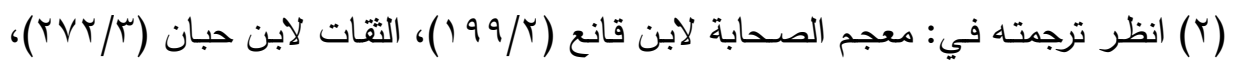

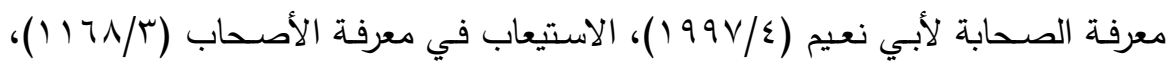

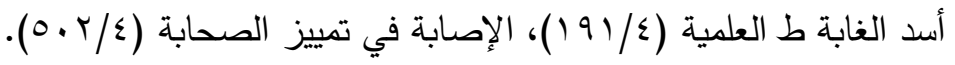


قال ابن حبان، وابن السّكن: لله صحبة.

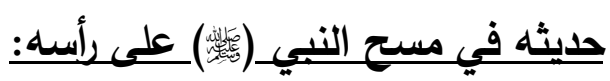

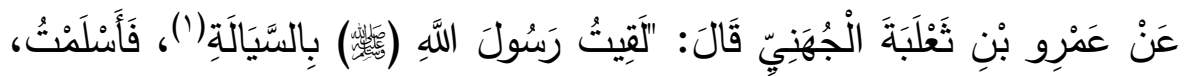

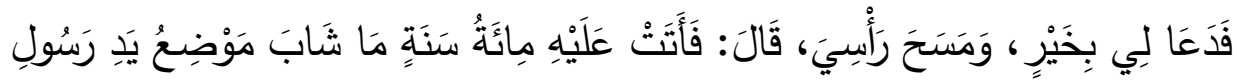

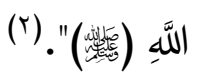

(1) السّيالة -بفتح أوله، وتخفيف ثانيه، وبعد اللام هاء- : أرض يطؤها طريق الحاج، قيل: هي أول مرحلة لأهل المدينة إذا أرادوا مكة. انظر : مراصد الاطلاع على على أسماء الأمكنة

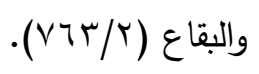

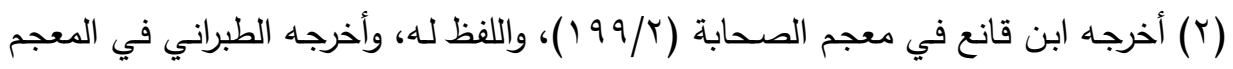

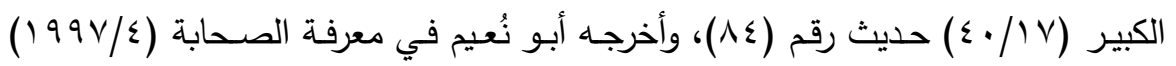

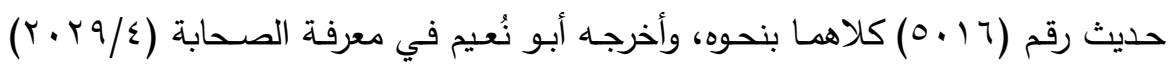

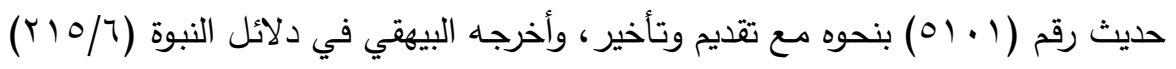

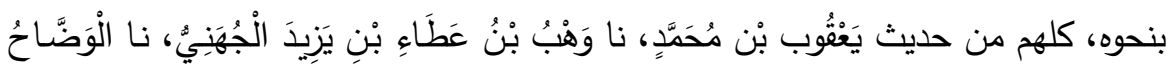

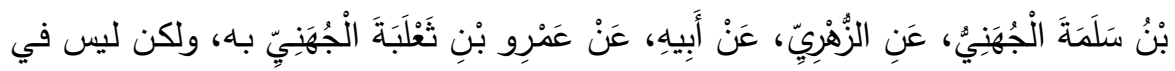

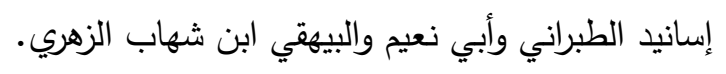

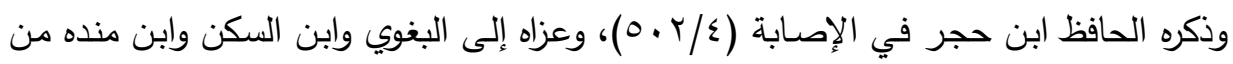

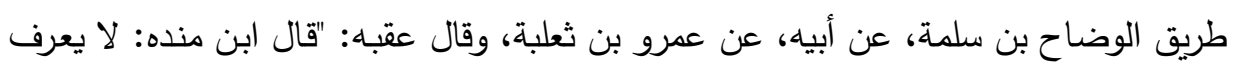

$$
\text { إلا من هذا الوجه"، وقال ابن حجر : "وفي إسناده من لا يعرف" }
$$

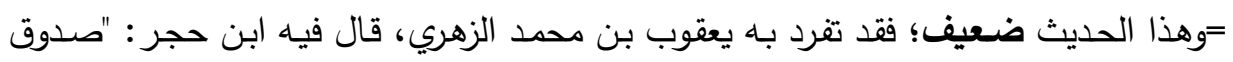

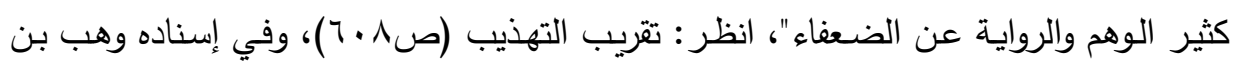
عطاء بن يزيد الجهني، والوضاح بن سلمة الجهني: مجهولان. 


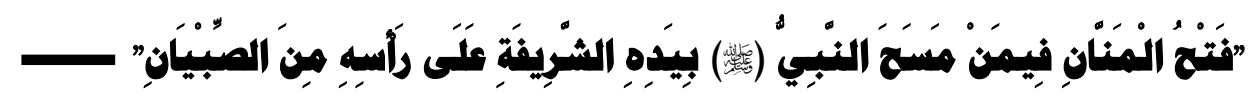

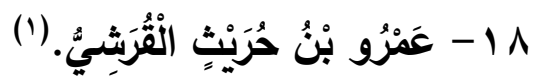

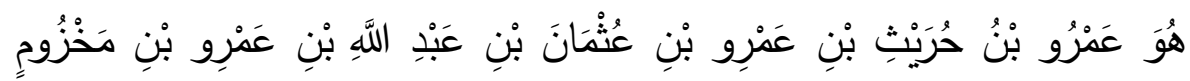

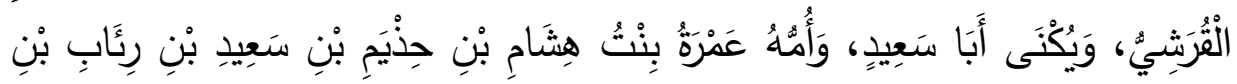
له ولأبيه صحبة. قال ابن حبّان: ولد في أيام بدر. وقال غيره: قبل الهجرة

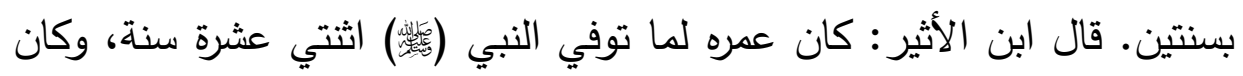
من أغنى أهل الكوفة، وشهذ القادسية، وأبلى فيها. سكن الكوفة، وزعموا أنه أول قرشي اتخذ بالكوفة دارًا، وكان له فيهابلها فيها قدر وشرف.

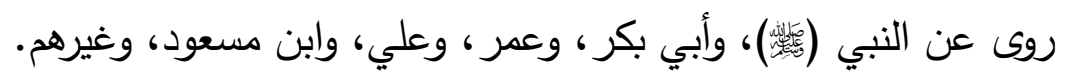

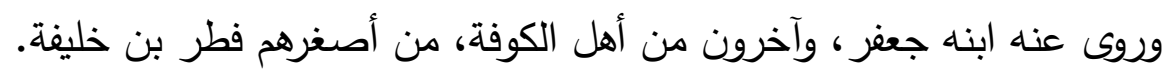

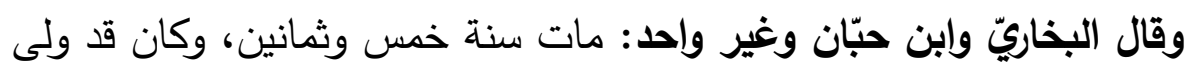

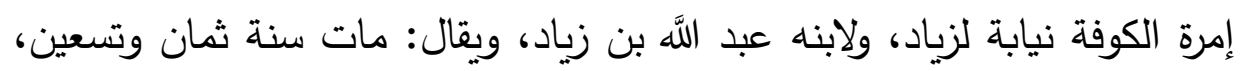
ولم يثبت.

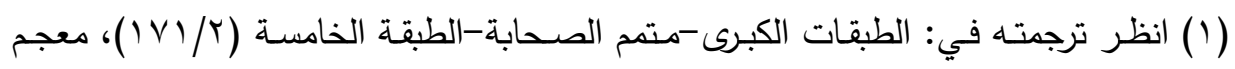

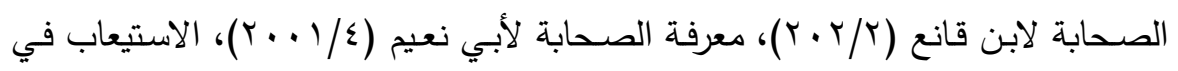

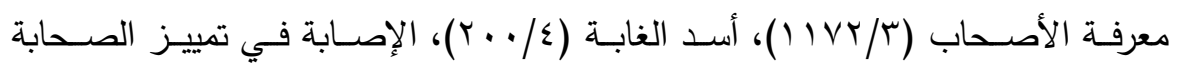
. (01./5) 


\section{حديثه في مستح النبي_(c)}

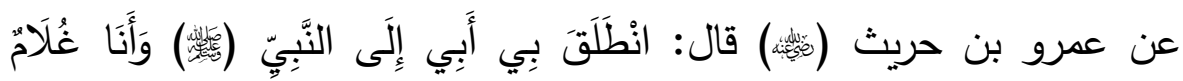

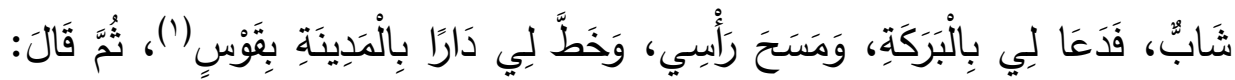

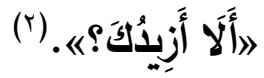

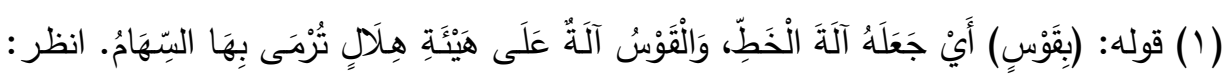

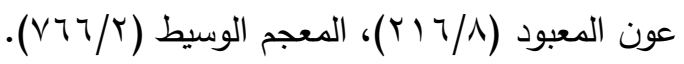

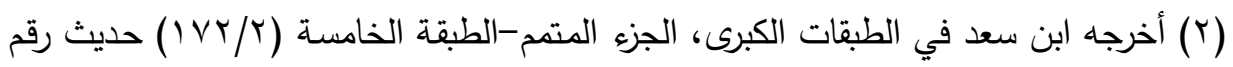

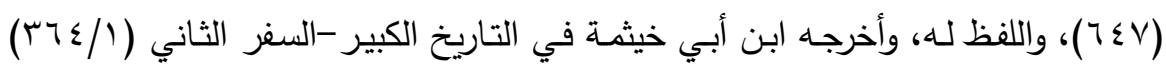

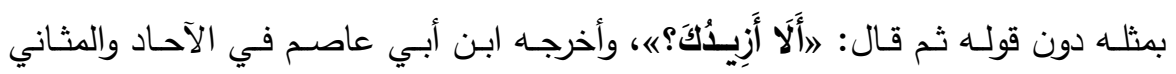

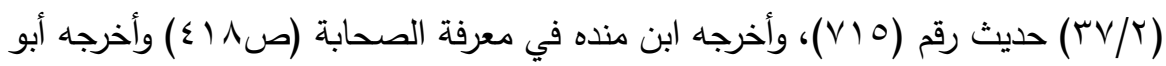

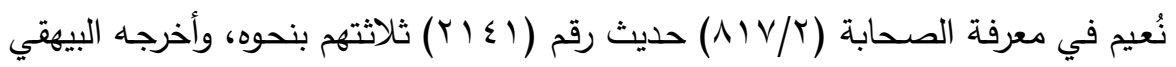

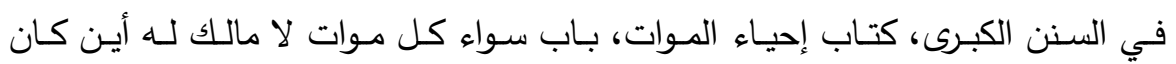

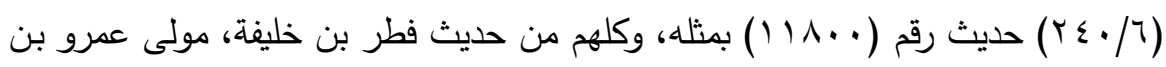
حريث، عن أبيـه زعم أنه سمع عمرو بن حريث بـه، وذكره ابن أبي حاتم في الجرح

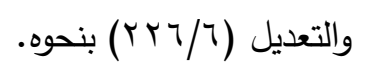

والحديث ضعيف؛ فيه خليفة القرشي المخزومي، والد فطر : لين الحديث، ولم يوثقه سوى ابن

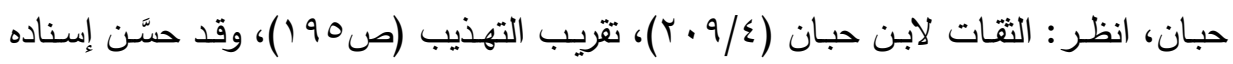

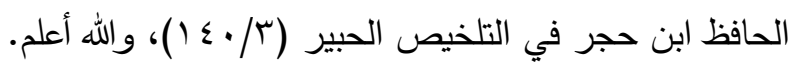

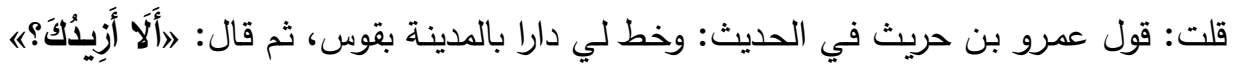

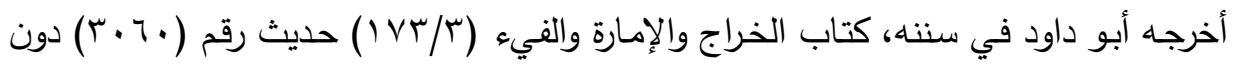

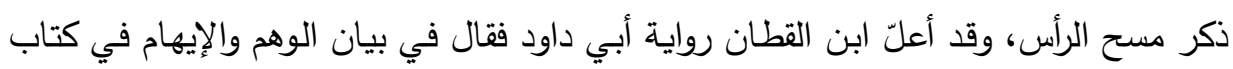

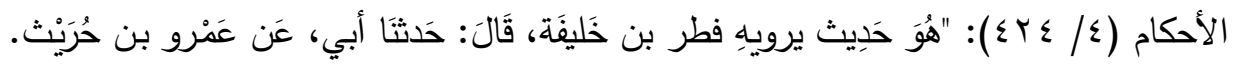

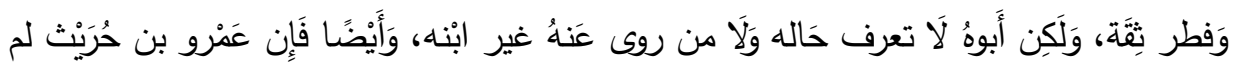

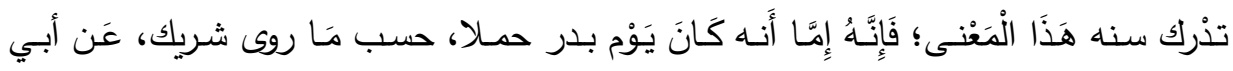

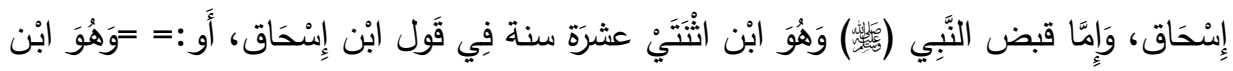




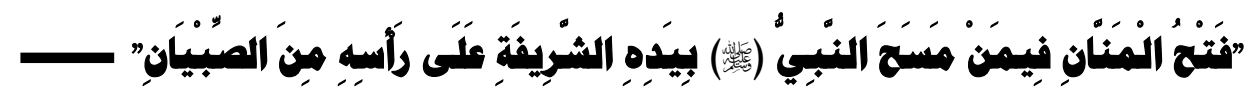

(') 19

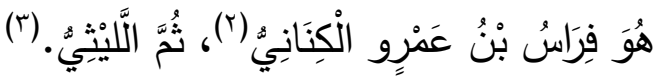

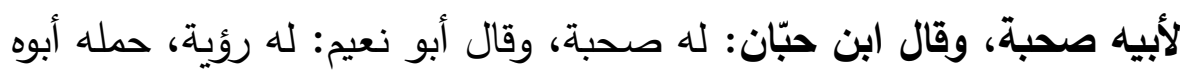

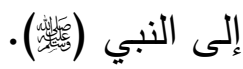

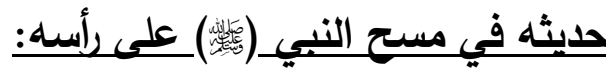

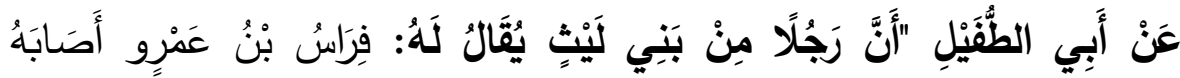

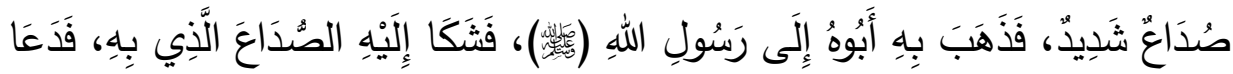

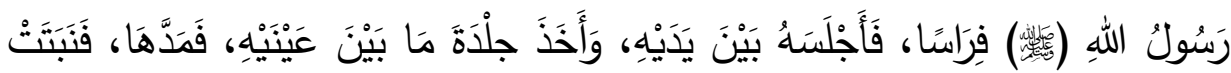

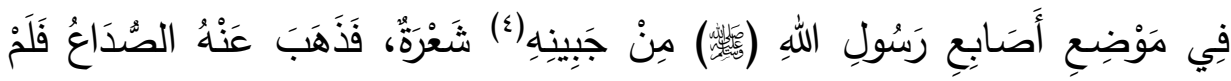

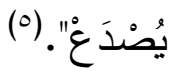

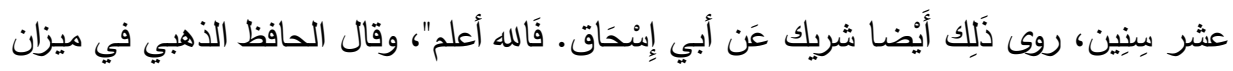

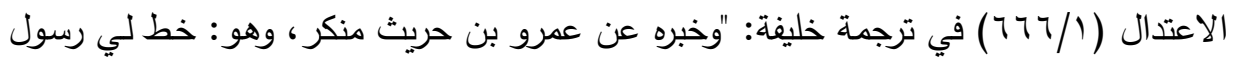

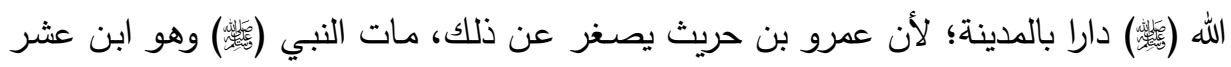

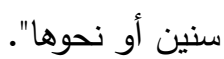

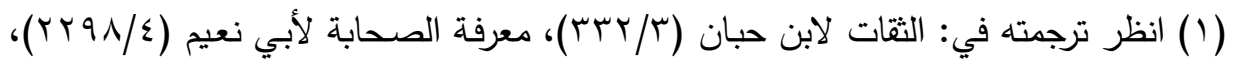

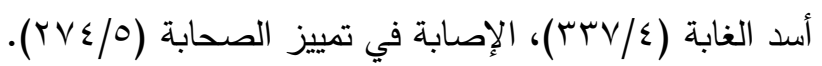

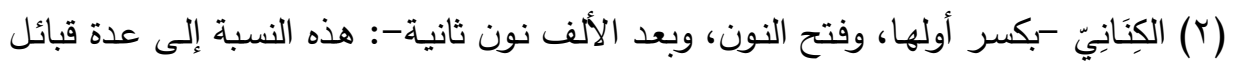

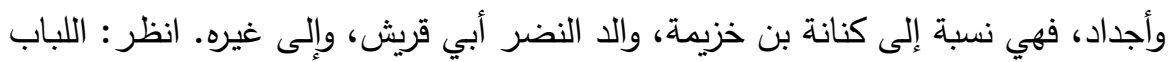

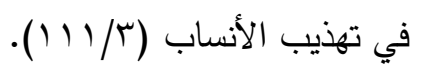

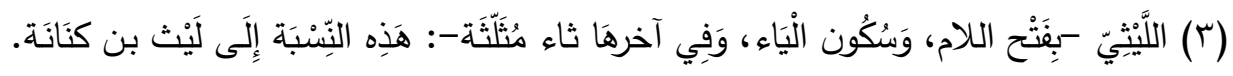

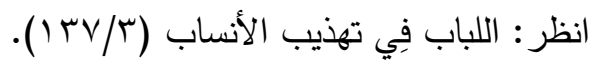

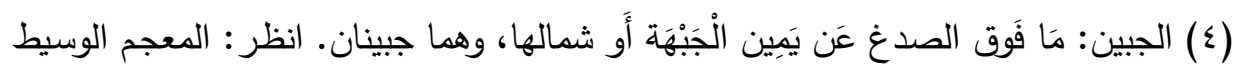

$$
\text { (1. (1/1) }
$$

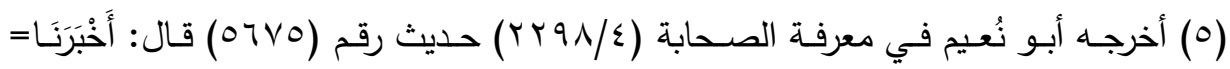


$=$

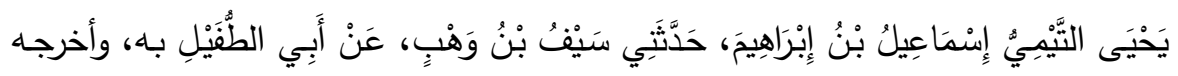

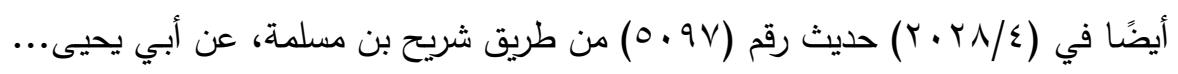

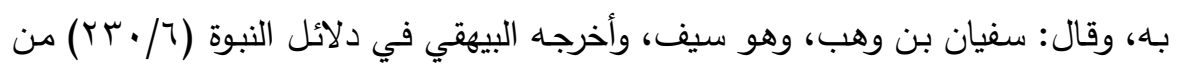

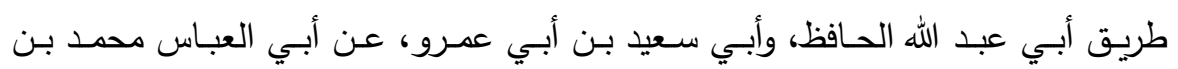

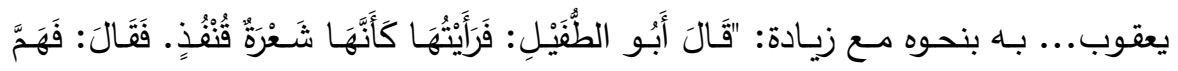

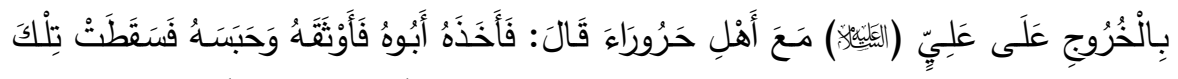

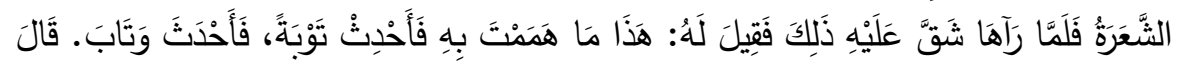

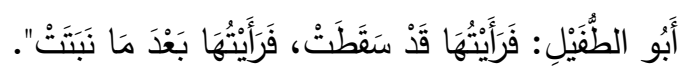

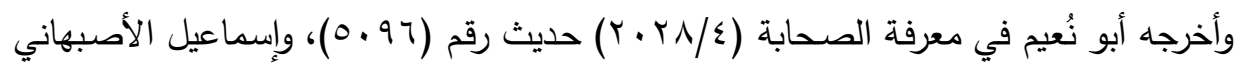

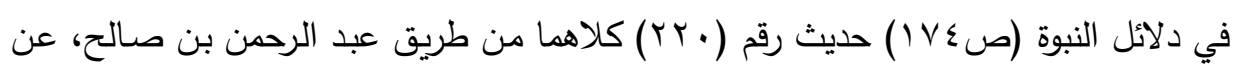

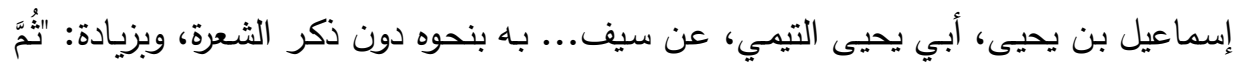

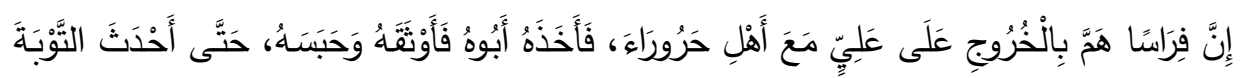
بَعْدَ ذَلَلكَدَ".

وذكره ابن حجر في الإصابة في تمييز الصحابة (YV/0)، وعزاه إلى الباوردي وابن منده من طريق أبي يحيى التيمي.

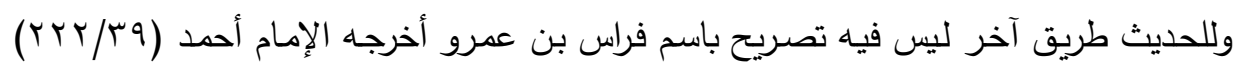

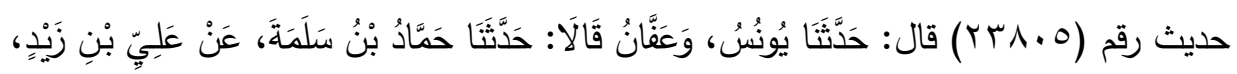

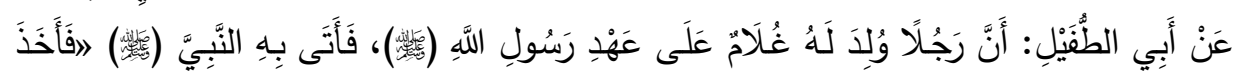

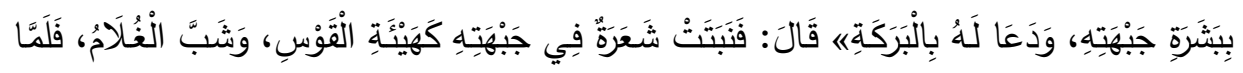

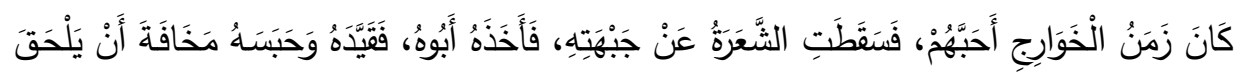

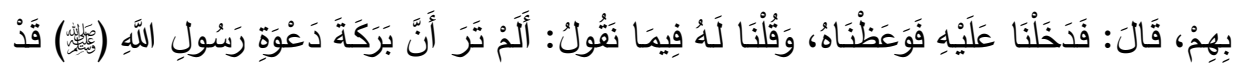

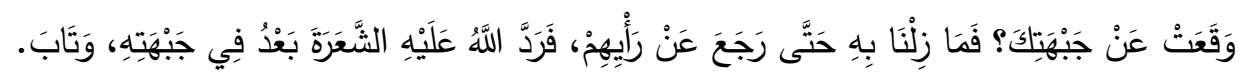

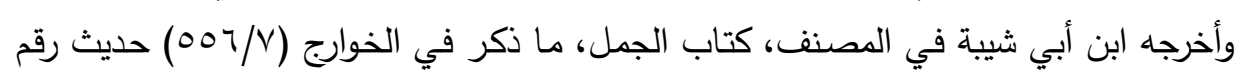

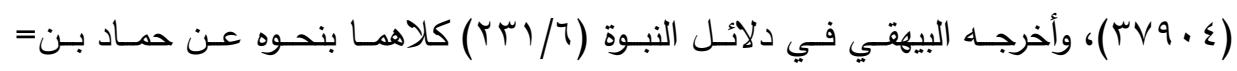




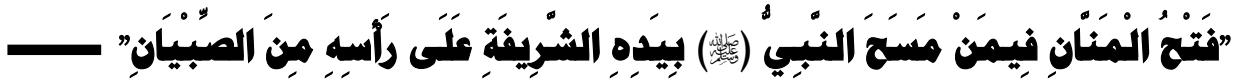

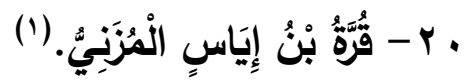

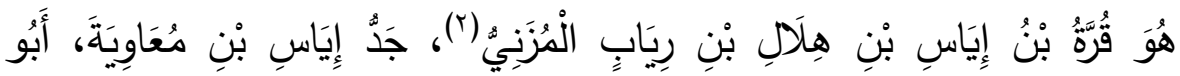

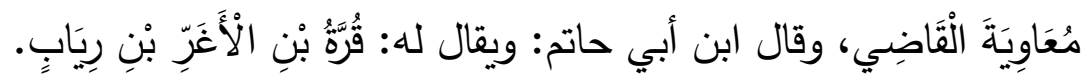

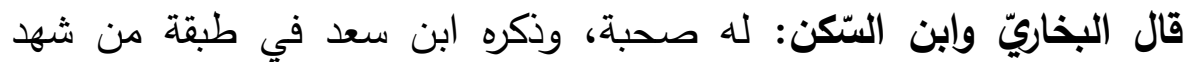

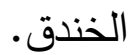

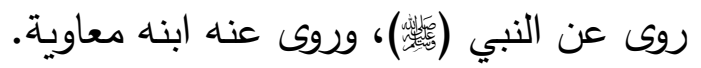
سكن البصرة، وقال أبو عمر: قتل في حرب الأزارقة في زمن معاوية، وأرّخه خليفة سنة أربع وستين، فيكون معاوية المذكور هو ابن يزيد بن فئ معاوية.

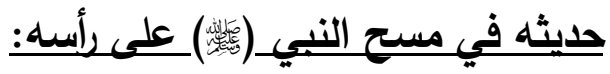

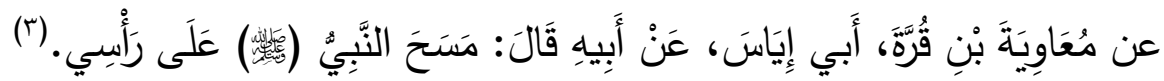

والحديث بهذا الإسناد: حسن لغيره ؛ مداره على سيف بن وهب التميمي، قال فيه ابن حجر :

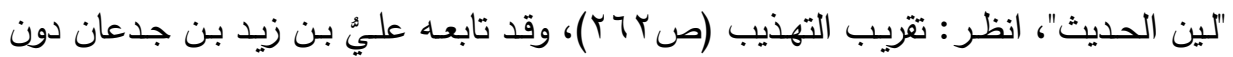
تسمية فراس، وعليٌّ ضعيف، انظر : تقريب التهذيب (ص ( +ـ)؛ فارتقى الحديث بهذه المتابعة.

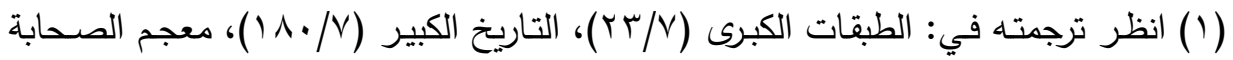

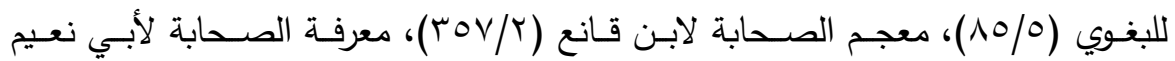

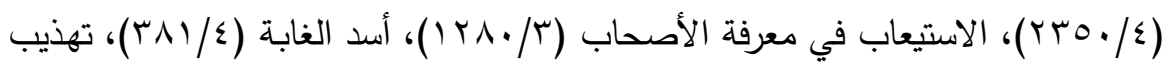

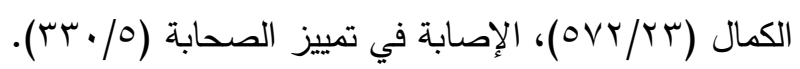

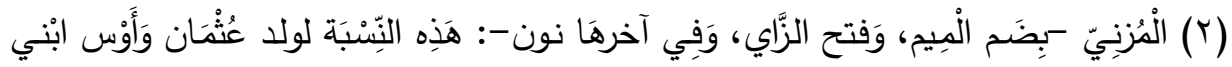

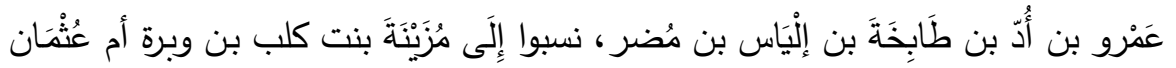

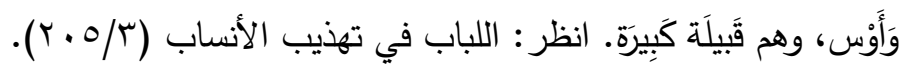

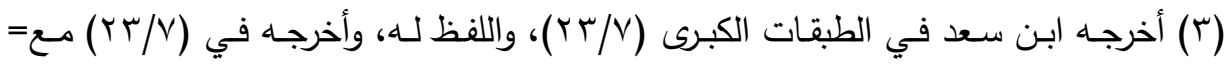

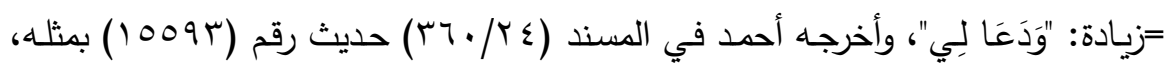

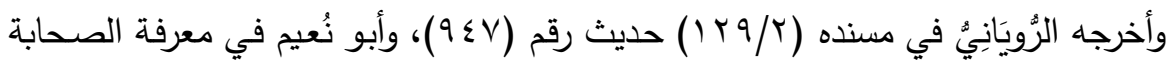

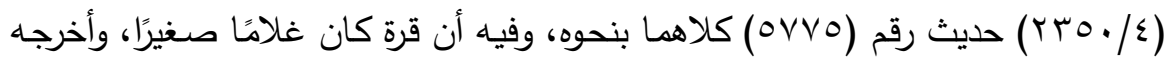




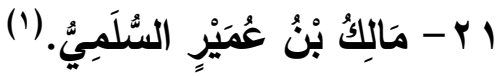

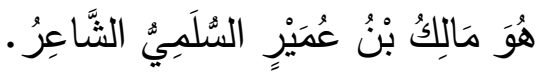

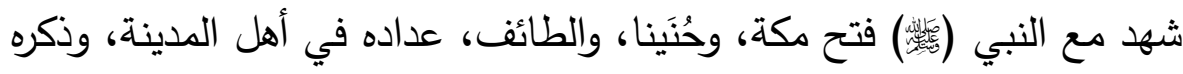

$$
\text { البغويّ وغيره في الصحابة. }
$$

وروى عنه إسماعيل بن سميع، والمنهال بن عمرو، ويزيد بن واصل السلمي.

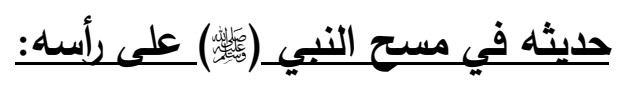

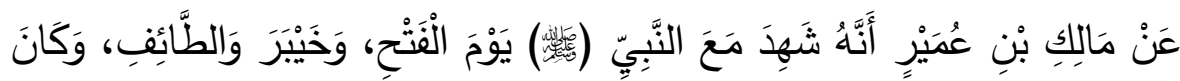

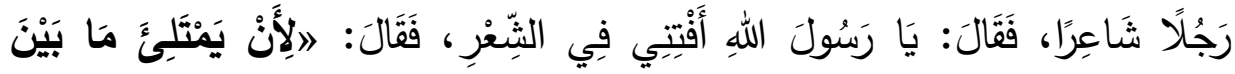

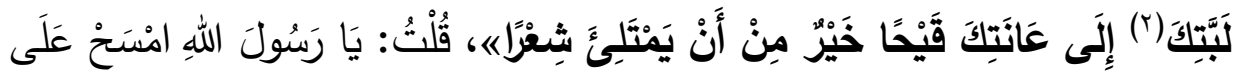

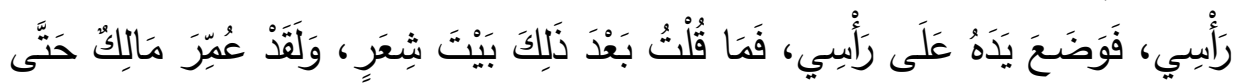

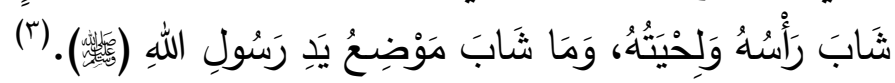

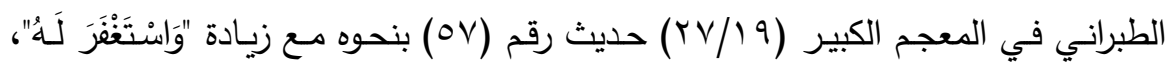

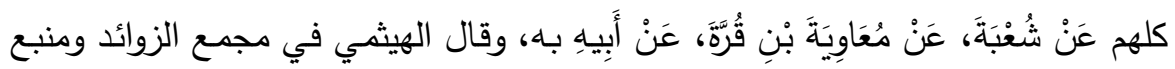

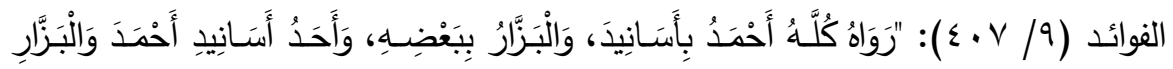

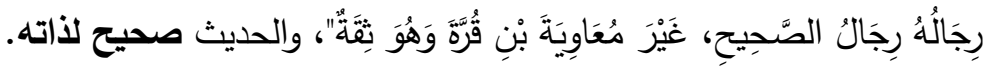

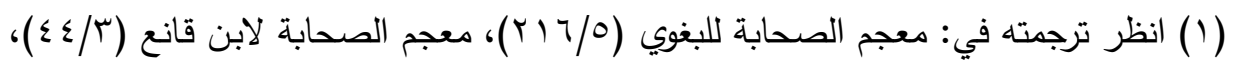

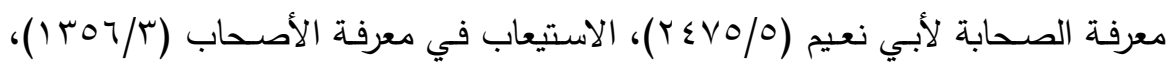

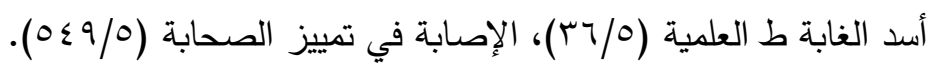

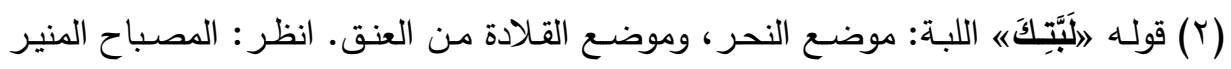

$$
\text { ( ) ( }
$$

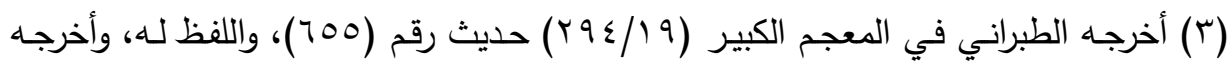

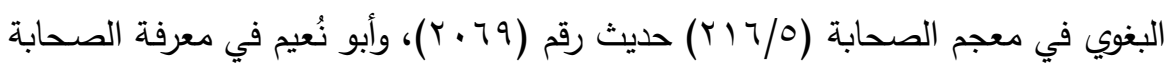

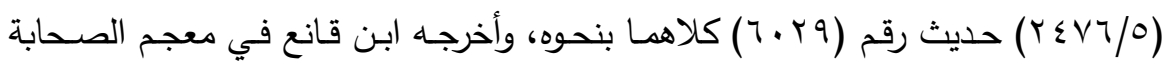

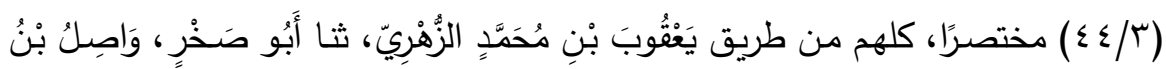




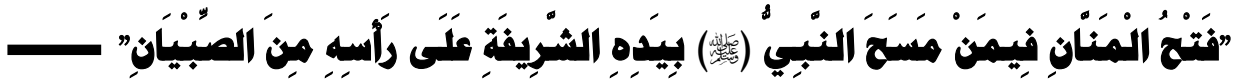

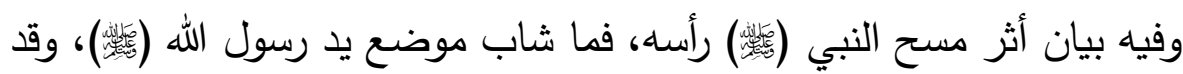

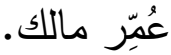

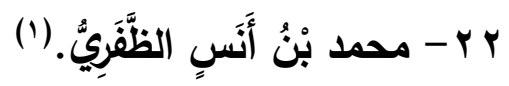

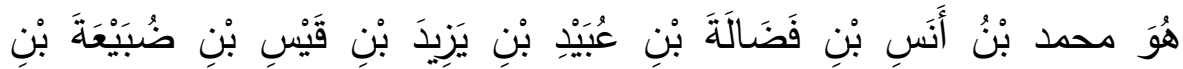

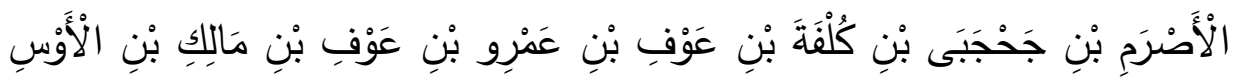

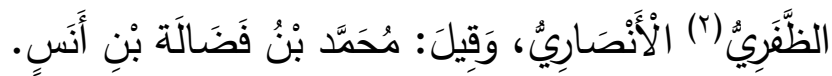

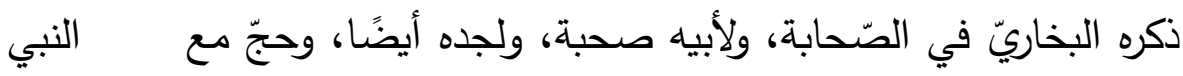

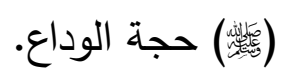

وفرّق البغويّ وابن شاهين وابن قانع وغيرهم بين محمد بن أنس بن فضالة

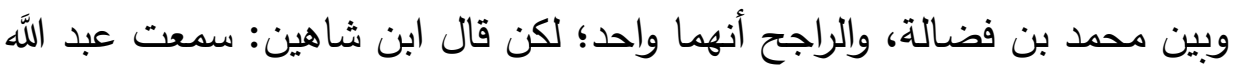

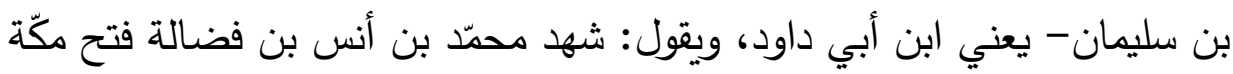

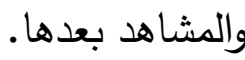

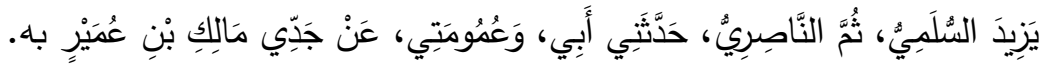

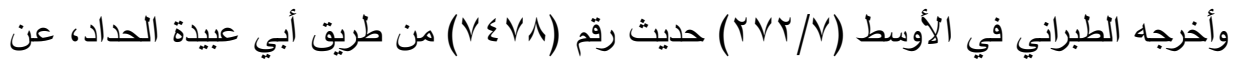
واصل بن يزيد... به مختصرًا.

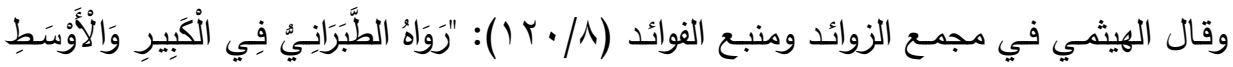

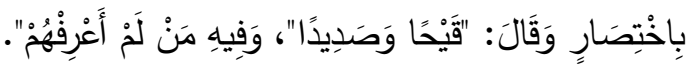

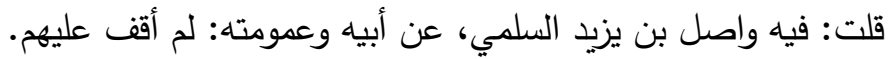

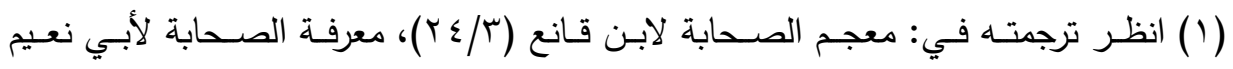

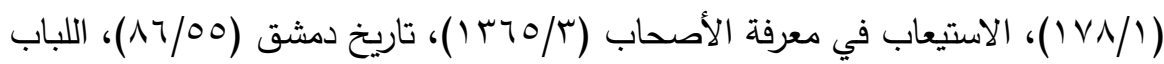

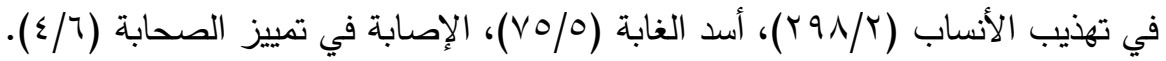

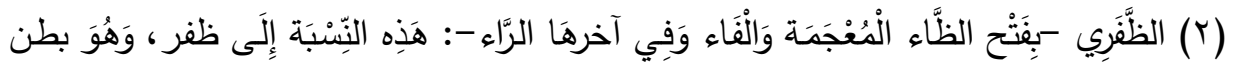

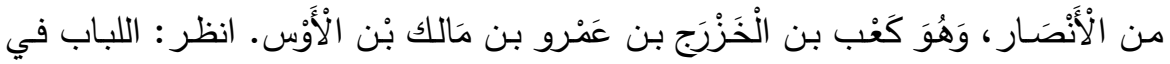

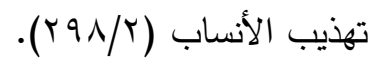




\section{مجلل كلية اصول الدين والدعوة بالموفية العدد التاسع والثلاثون}

وروى عنه ابنه يعقوب بن محمد بن فضالة، ومحمد بن أنس بن فضالة.

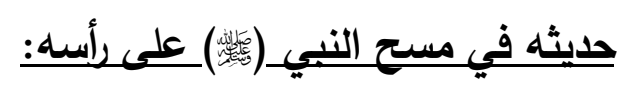

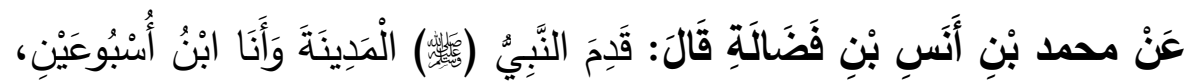

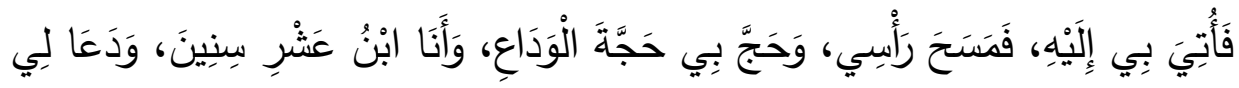

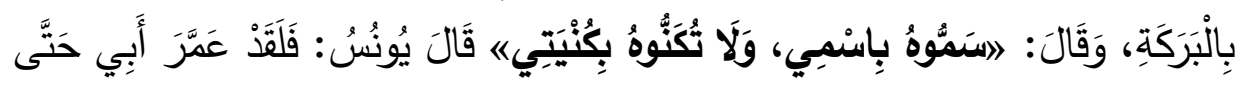

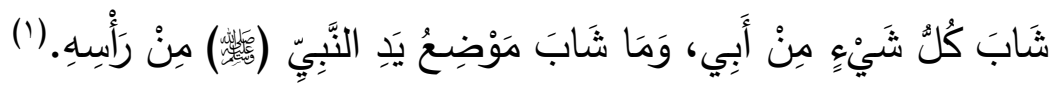

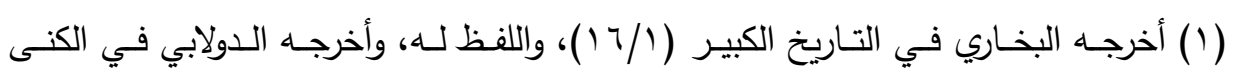

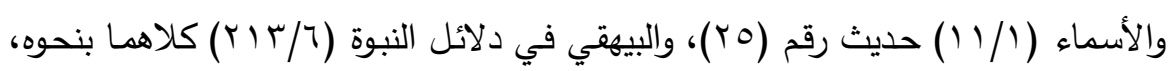

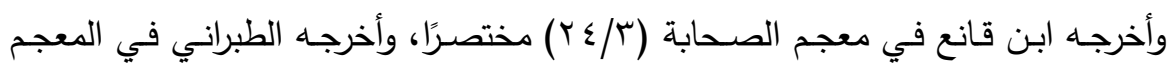

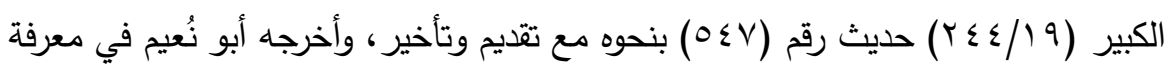

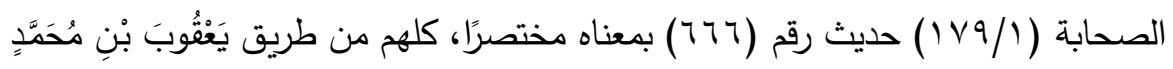

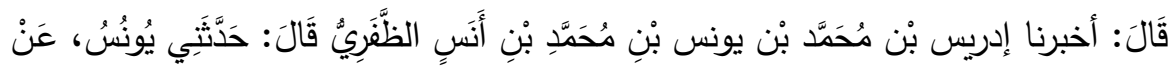

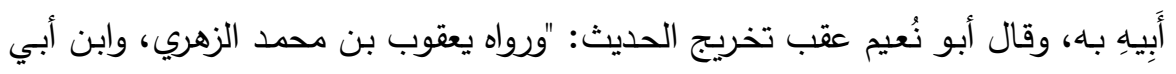

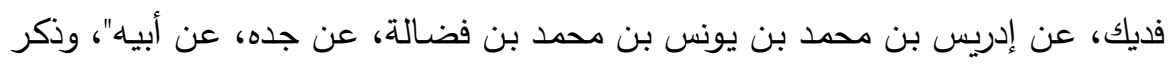

$$
\text { الحديث. }
$$

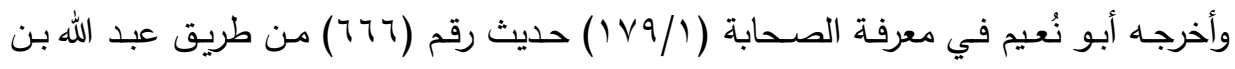
كثير، عن يونس بن محمد الظفري... باه بمعناه.

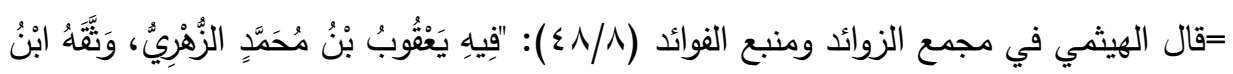

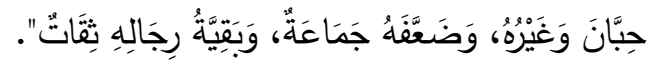

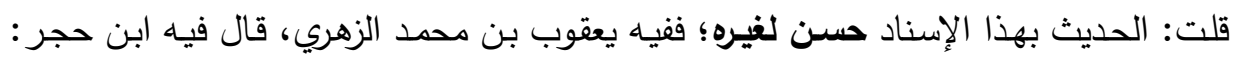

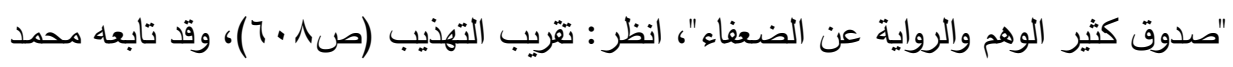

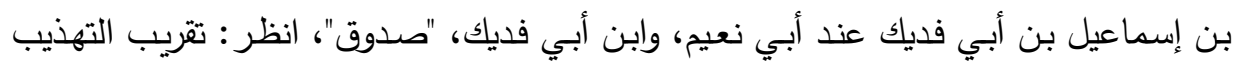

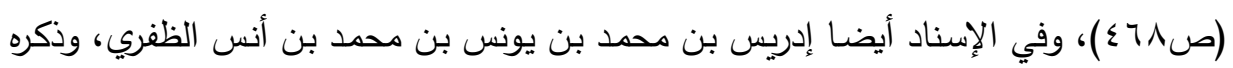

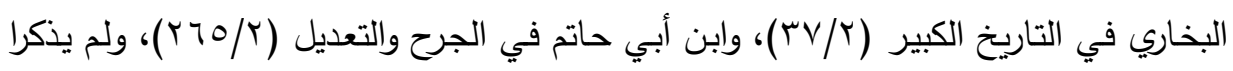

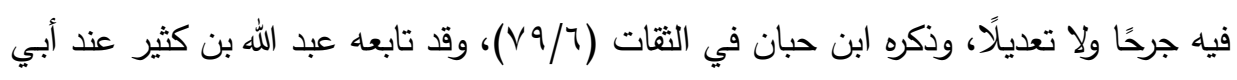




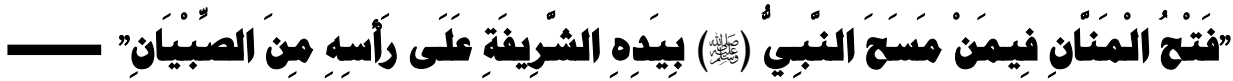

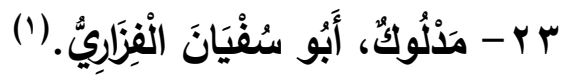

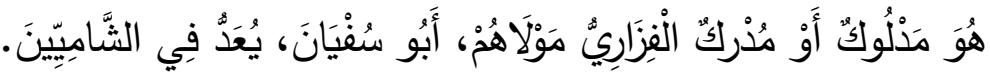

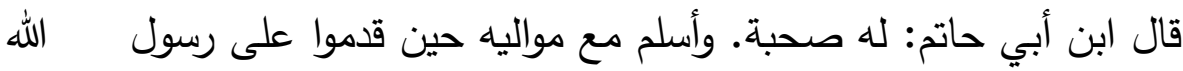

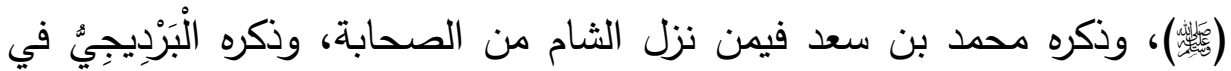
الأسماء الهفردة من الصحابة.

روت عنه آمنة أو أمية بنت أبي الثعثثاء الفزارية، وقَطَبََُُ مولاة أبي الثُعثاء.

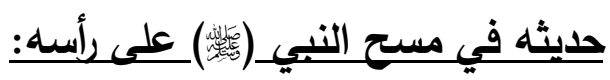

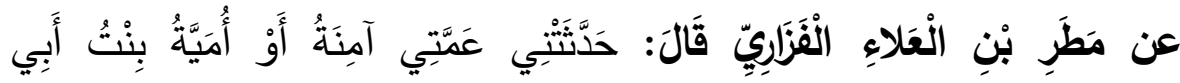

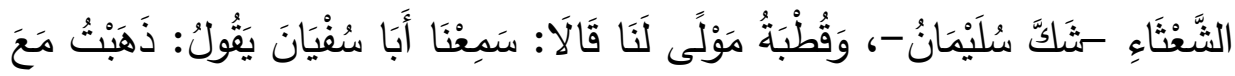

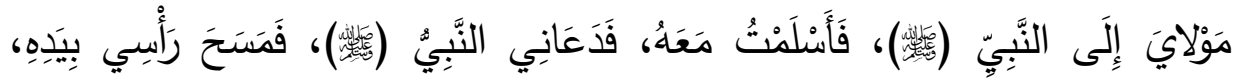

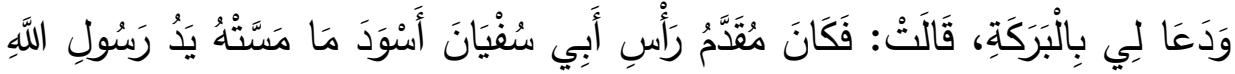

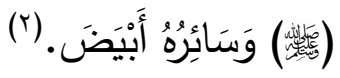

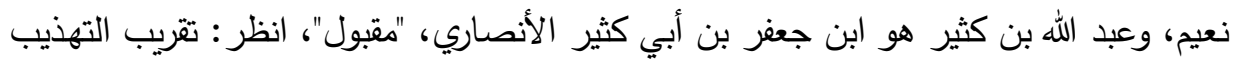

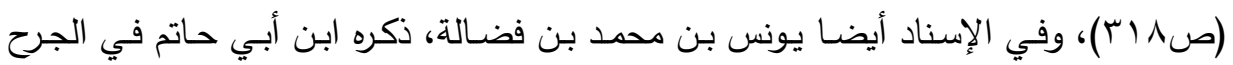

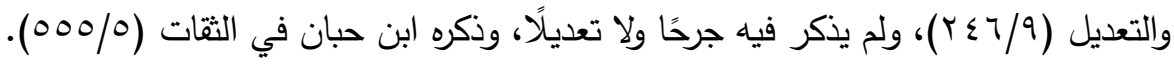

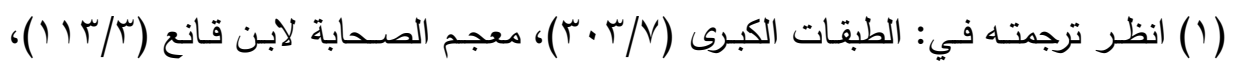

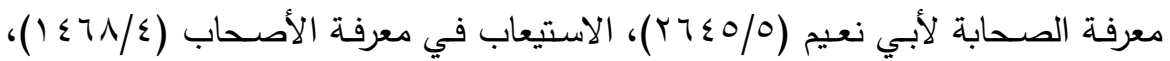

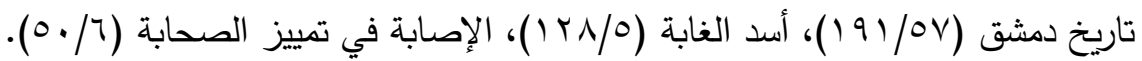

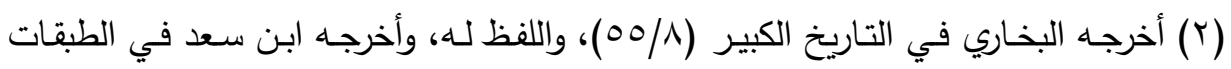

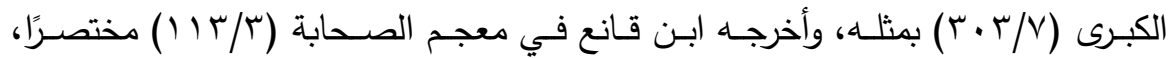

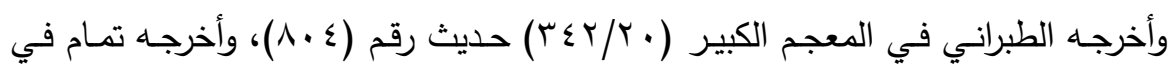

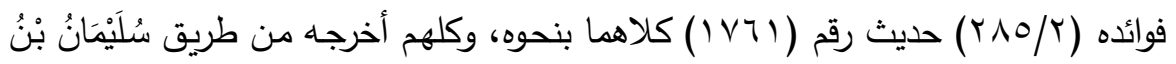

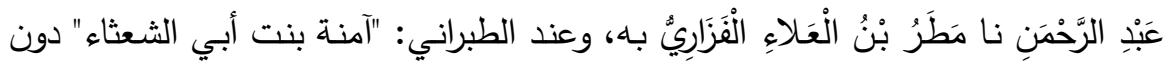




\section{مجلح كلية أصول الدين والدعوة بالموفية العدد التاسع والثلاثون}

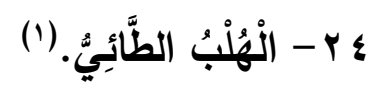

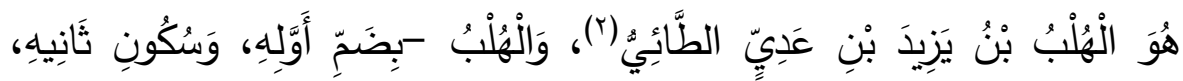

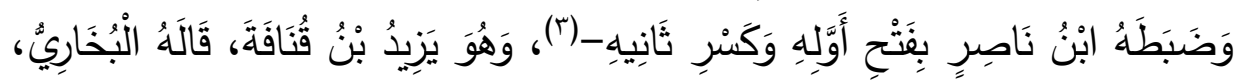

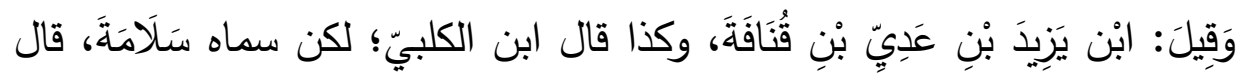
أبو نعيم: ولا يصح. وذكره ابن سعد في طبقة مسلمة الفتح.

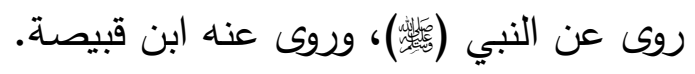
حليثه في مستح النبي_(ئي

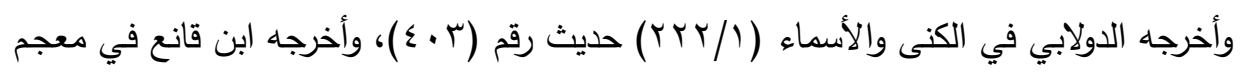

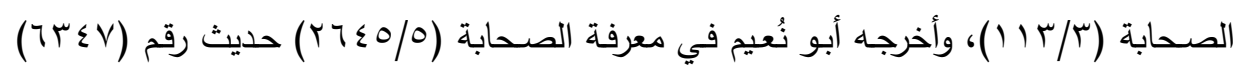
كلهم بنحوه من طريق علي بن حجر، عن مطر بن العلاء الفزاري... به بنحوه، وعندهم جميعًا

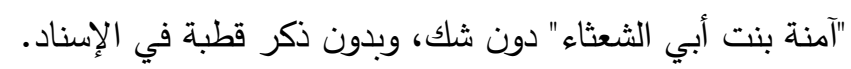

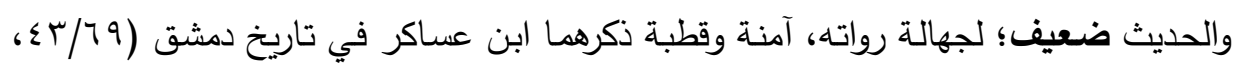

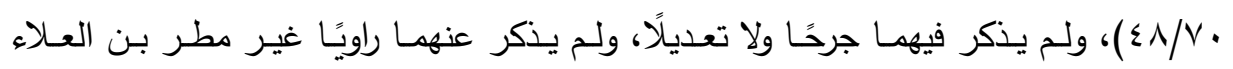

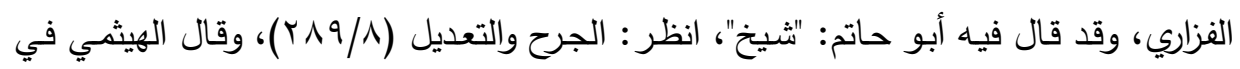

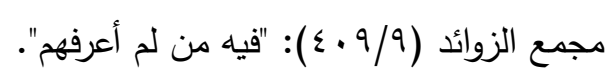

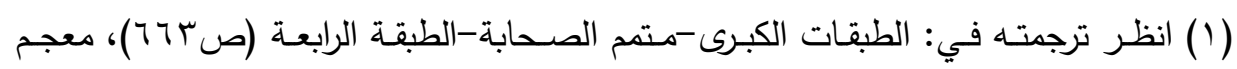

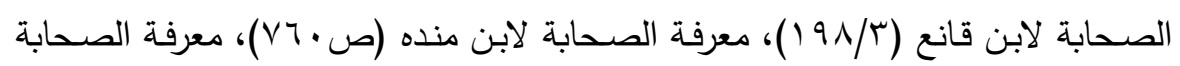

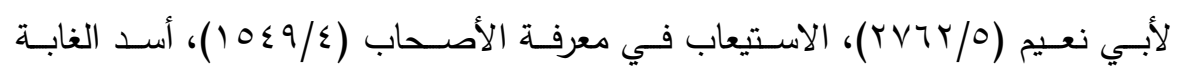

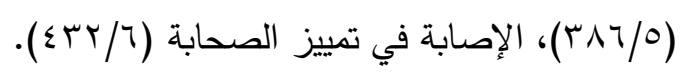

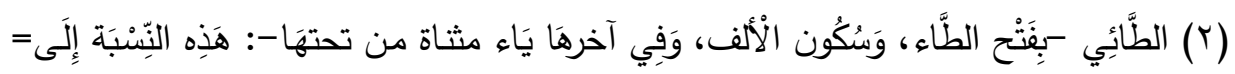

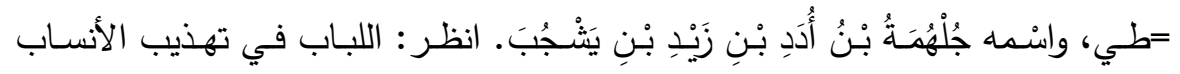




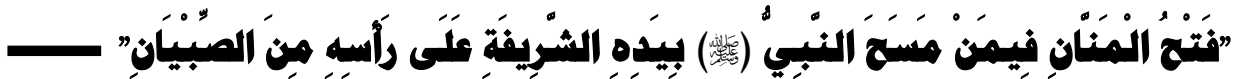

ذكر هذا الحديث غير مسند ابن سعد في الطبقات الكبرى (؟/YT)، وخليفة بن

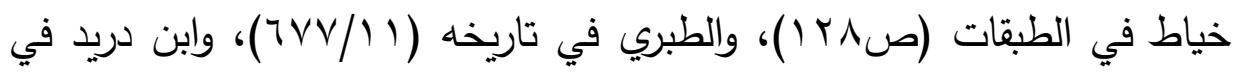

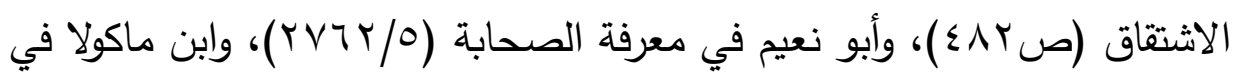

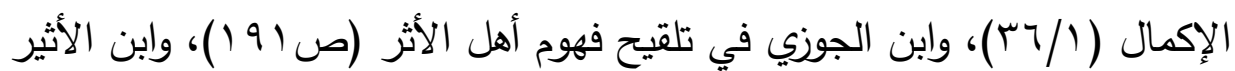

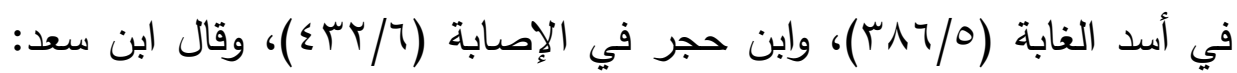

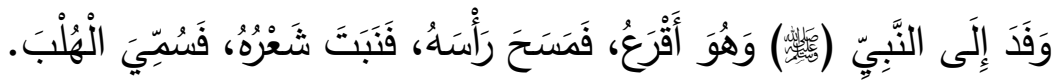

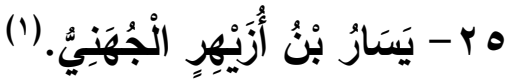

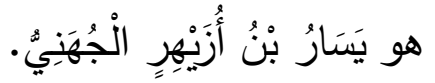

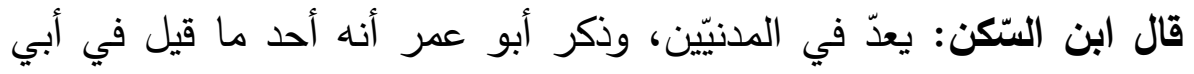
الغادية، وردّه ابن فتحون، وذكره ابن حجر في القسم الأول.

روت عنه ابنته عمرة، ولها صحبة.(ץ)

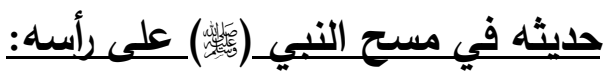

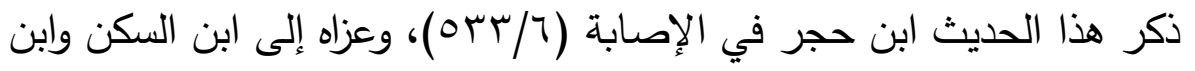

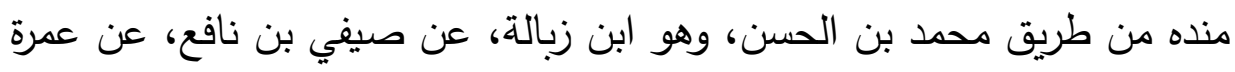

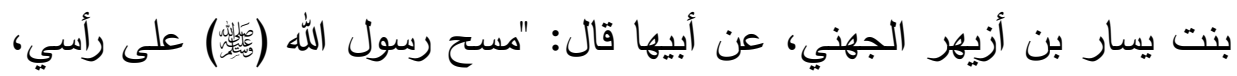

وكساني بردين، وأعطاني سيفًا"، قالت: "فما شاب رأس أبي حتى لقي الله (ئَّلَ)".

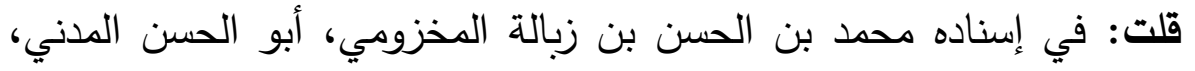

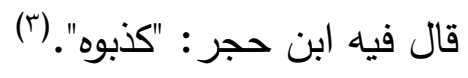

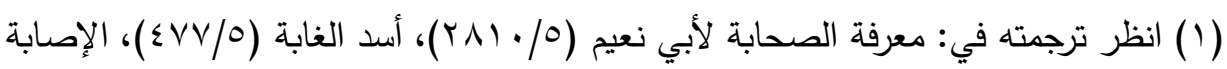

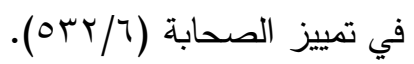

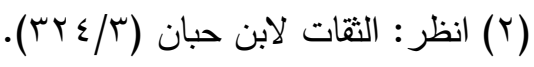

$$
\begin{aligned}
& \text { (T) تقريب التهذيب (ص \& ع ع). }
\end{aligned}
$$




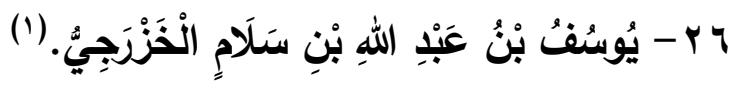
يوسف بن عبد اللَّه بن سلام بن الحارث الخزرجي الإسرائيلي، قال الواقديّ:

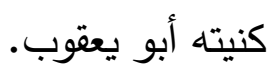

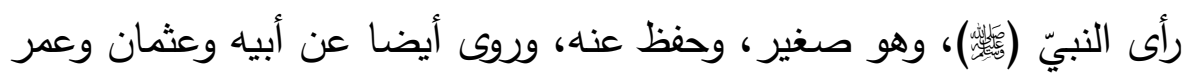
وعليّ وغيرهم.

وروى عنه عمر بن عبد العزيز، ويزيد الأعور، ويحيى بن أبي الهيثم. ونقل ابن أبي حاتم أنه قال لأبيه: ذكر البخاري أنّ ليوسف صحيّة ويربة، فقال أبي: لا، له رؤينة. انتهى، وكلام البخاريّ أصحّ. وذكره ابن سعد في الطّبقة الخامسة من الصّحابة. وذكره جماعة ممن ألف في الصّحابة، وقال خليفة بن خياط: توفي في خلافة عمر بن عبد العزيز.

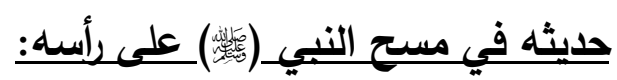

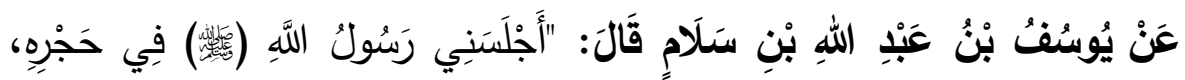

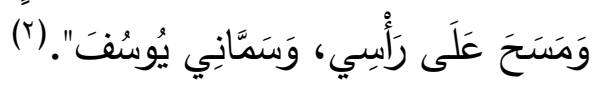

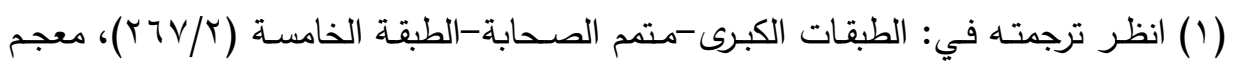

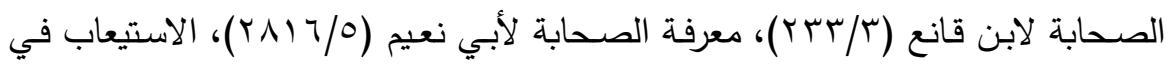

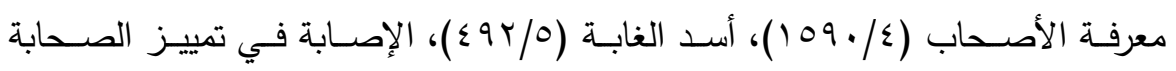
. $0 \leqslant \% / \tau)$

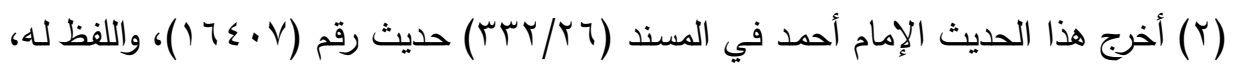

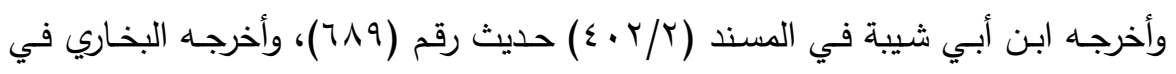

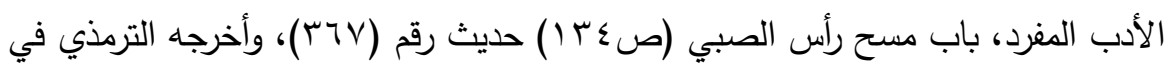

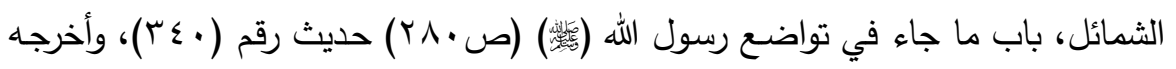

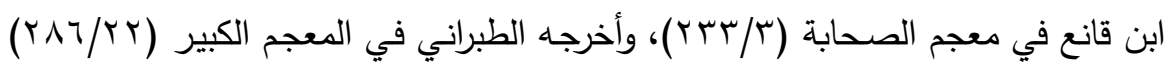

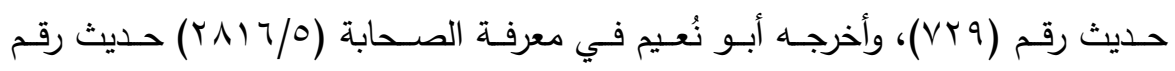

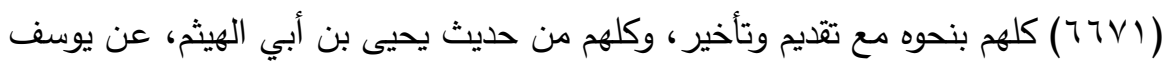




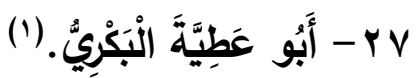

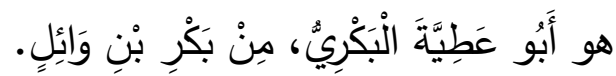

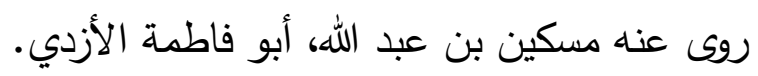

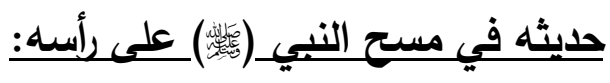

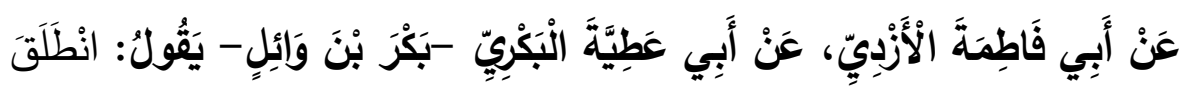

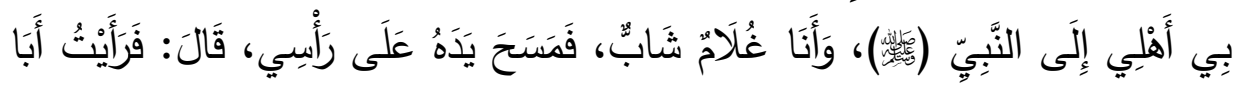

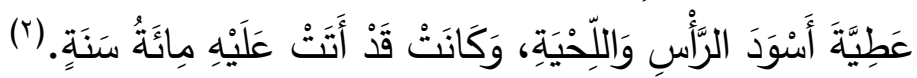

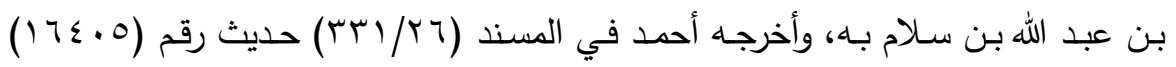

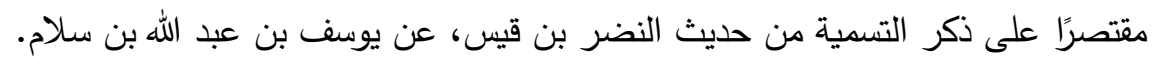
والحديث صحيح لذاته؛ فرواته ثقات، وسنده متصل.

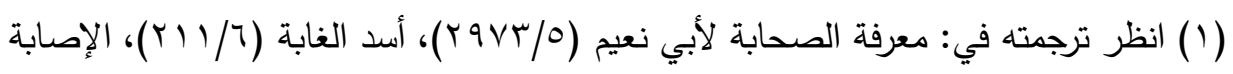

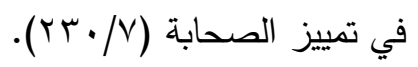

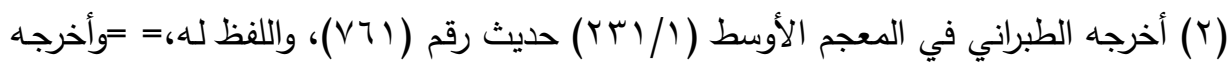

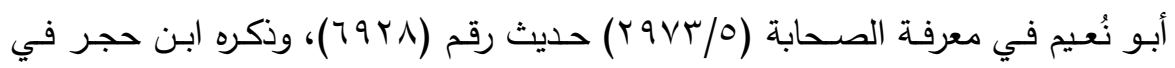

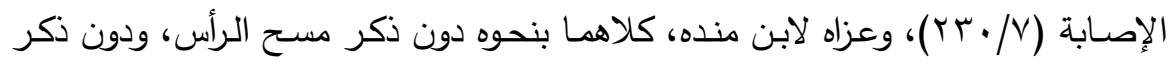

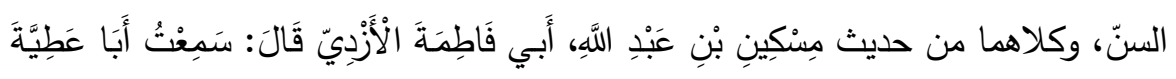

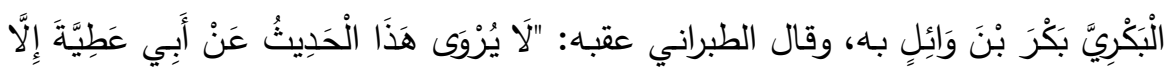

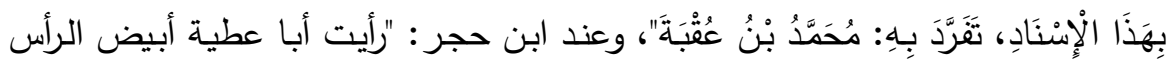
واللحية، ورأيته يعتمّ بعمامة بيضاء".

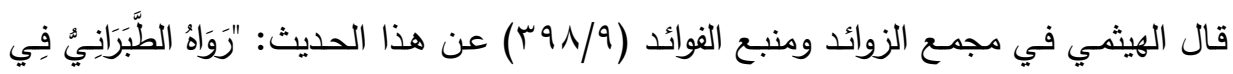

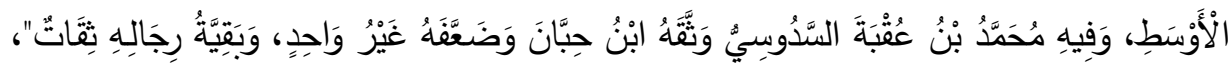

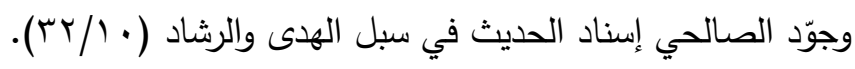

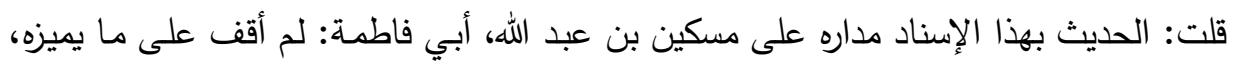

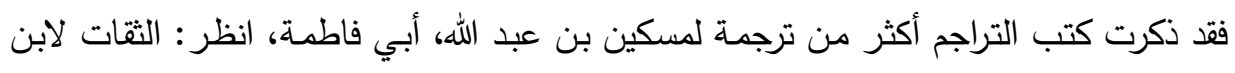




\section{مجلح كلية اصول الدين والدعوة بالموفية العدد التاسع والثلاثثون}

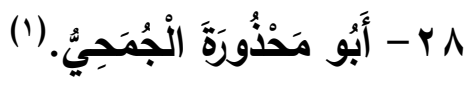

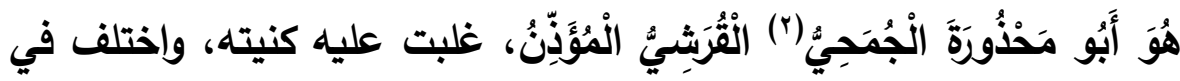

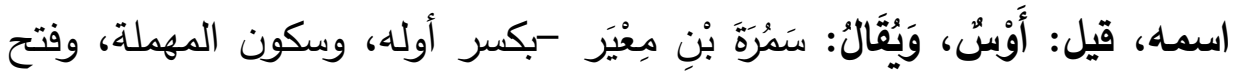
التحتانية المثناة، وهذا هو المشهور، وحكى ابن عبد البرّ أنّ بعضهم ضبطه بفتح العين وتثديد التحتانية المثناة بعدها نونـا(؟) ابْنِ رَبِيعَةَ بْنِ مِعْيَرِ بْنِ عَرِيجِ بْنِ

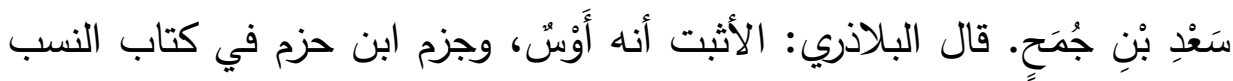
بأن سمرة أخوه، وخالف أبو اليقظان في ذلك، فجزم بأن أوس بن معير قتل يوم

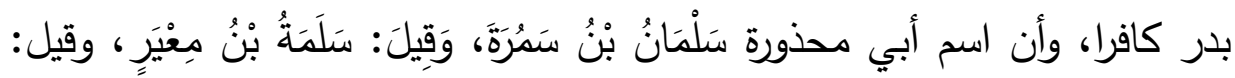

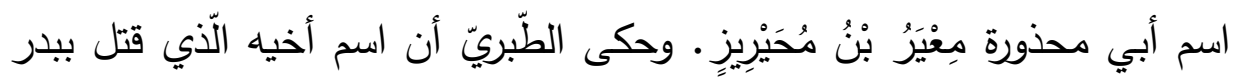
أنيس. وقال أبو عمر : اتفق الزبير وعمه وابن إسحاق والمسيبي على أن اسم أبي محذورة أوس، وهم أعلم بأنساب قريش، ومن قال: إن اسمه سلمة فقد أخطأ. روى عن النبي (赔). وروى عنه الأسود بن يزيد النخعي، وأوس بن خالد، والسائب المكي، وغيرهم.

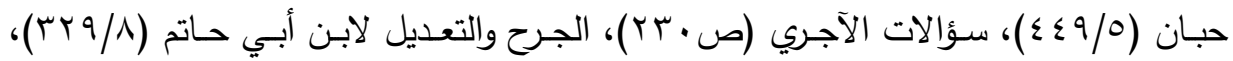

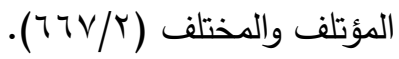

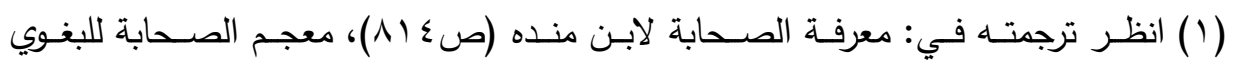

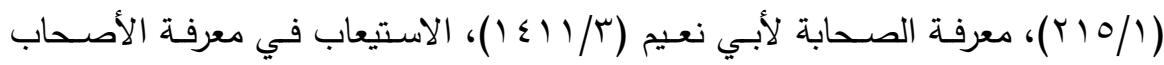

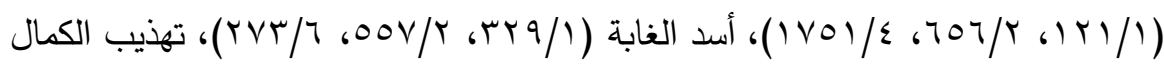

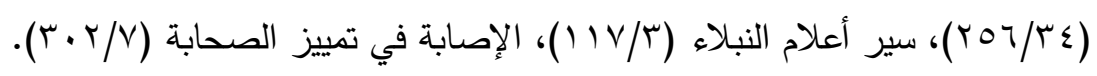

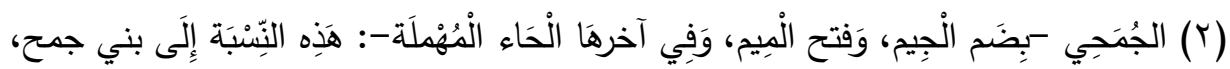

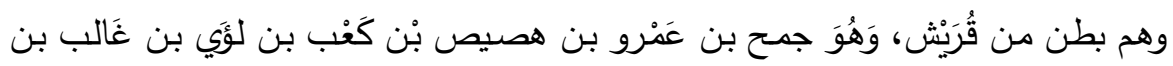

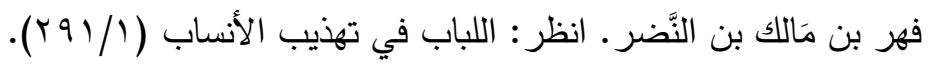
(r) انظر : الإصابة في تمييز الصحابة (r/ (r) 


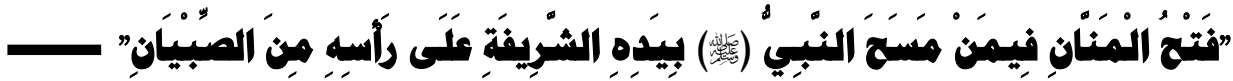

قال ابن منده: نزل الثام. وقال ابن الكلبيّ: لم يهاجر أبو محذورة، بل أقام بمكة إلى أن مات بعد موت سمرة بن جندب، وقال غيره: مات سنة تسع وخمسين، وقيل: سنة تسع وسبعين.

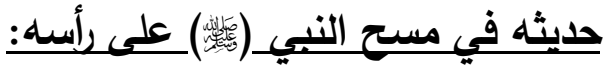

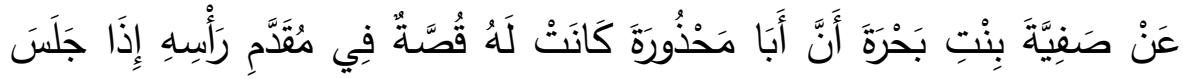

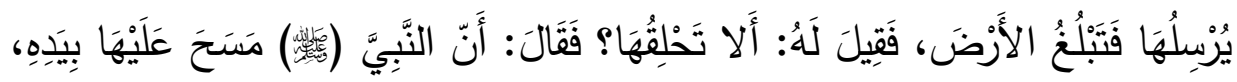

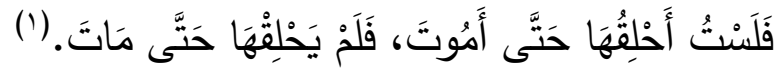

(1) أخرجه البخاري في التاريخ الكبير (ع/ IVV)، واللفظ له، وأخرجه الفاكهي في أخبار مكة

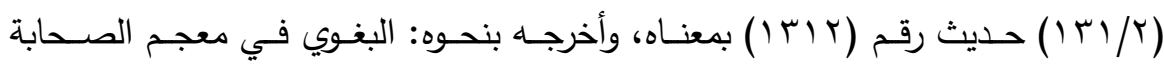

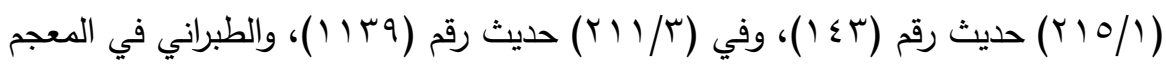

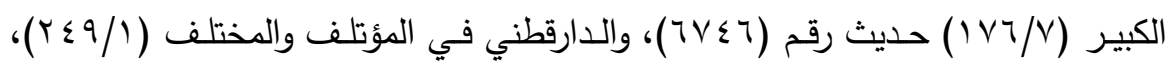

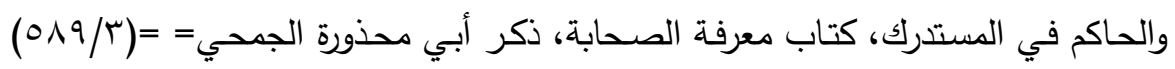

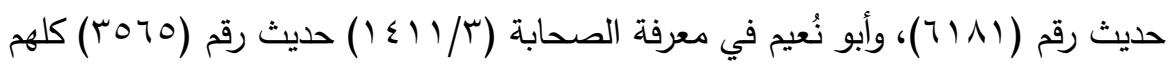

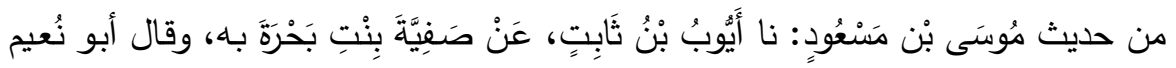

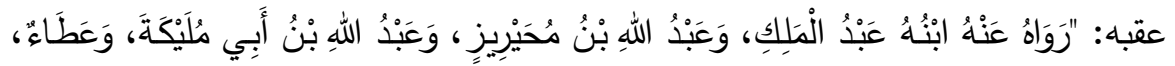

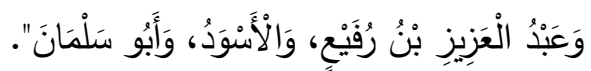

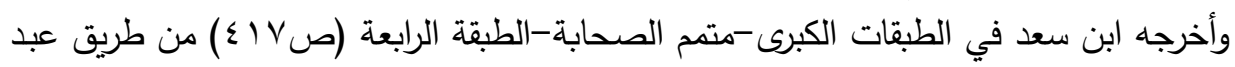
الملك بن أبي محذورة، عن أبيه باه بمعناه.

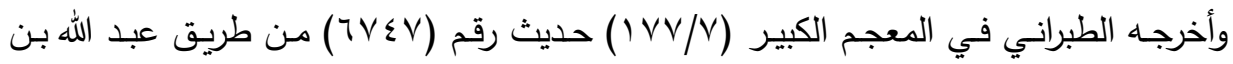

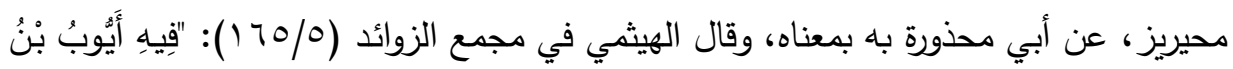

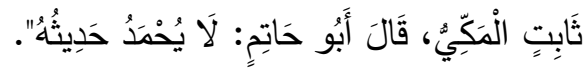

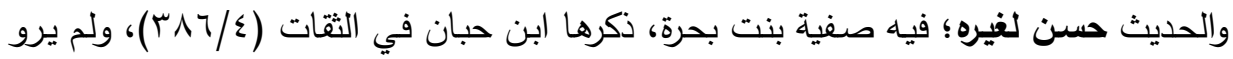

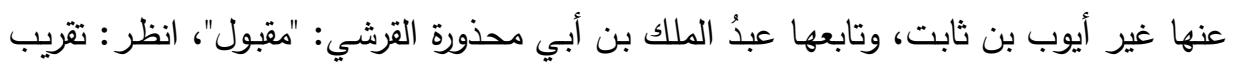

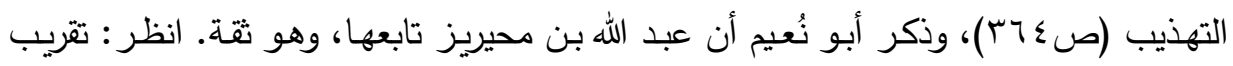




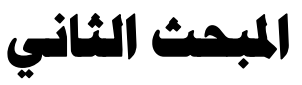

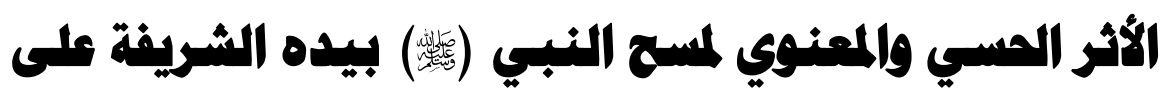

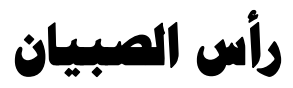

وفيه مطلبان:

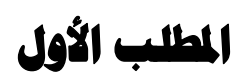

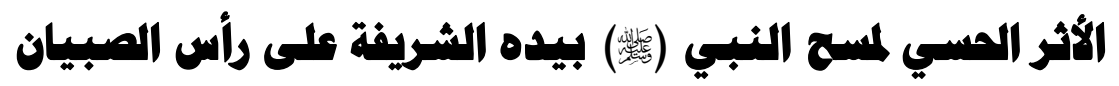

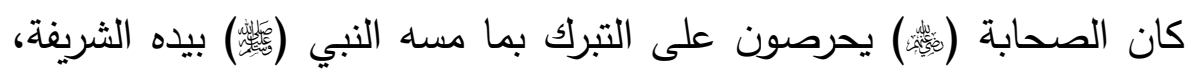

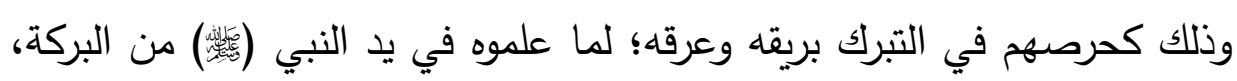

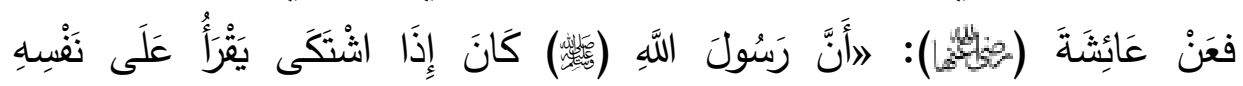

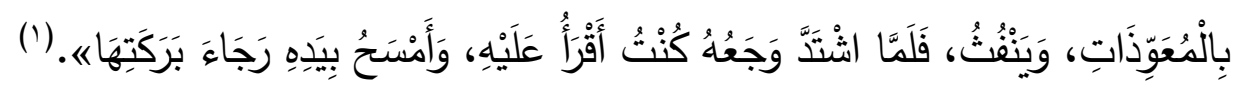

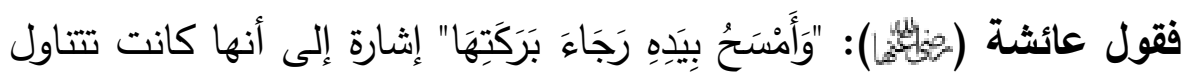

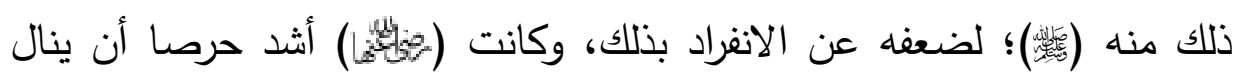

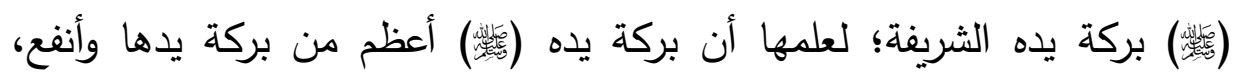

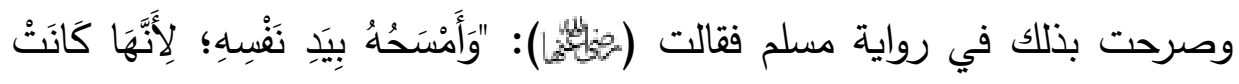

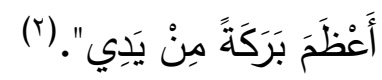

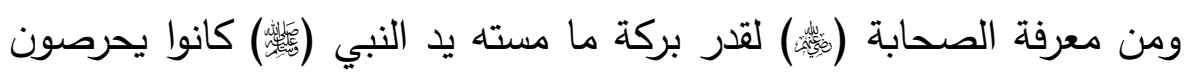
أن يمسح النبي (赔) على رؤوس صبيانهم؛ حتى تحصل البركة لهم، وفيما يلي

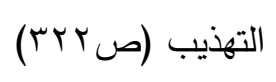

(1) متفق عليه أخرجه البخاري، كتاب فضائل القرآن، باب فضل المعوذات (؟/ • (1 ) حديث

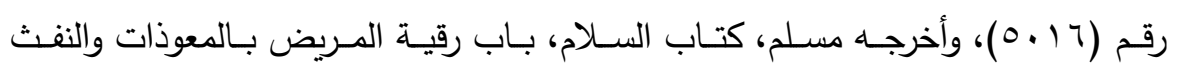

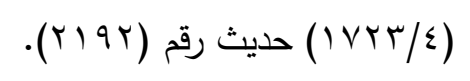

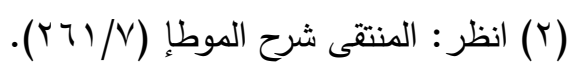




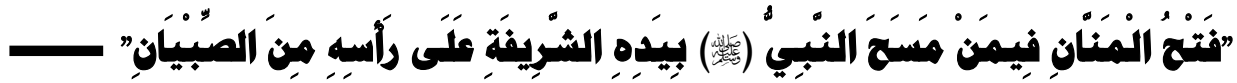

-من خلال الأحاديث التي ذكرت في البحث- بيان بعض الآثار التي ظهرت

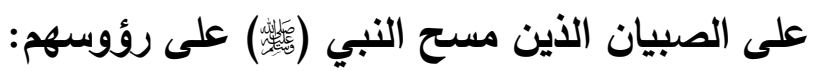

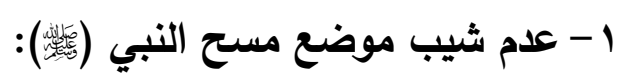

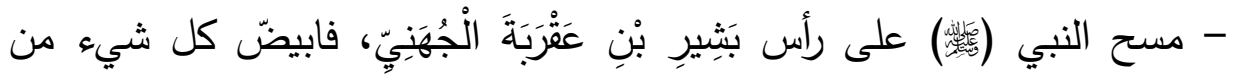

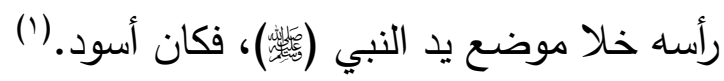

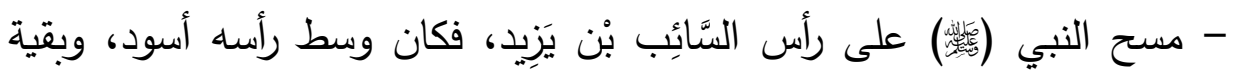

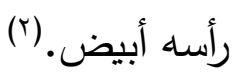

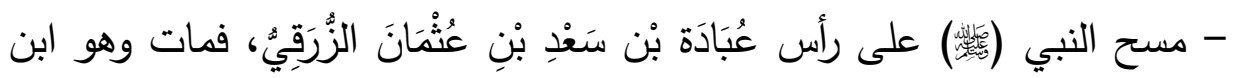
ثمانين سنة، وما شاب". (")

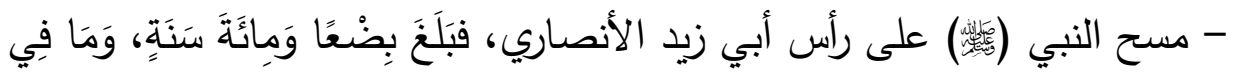

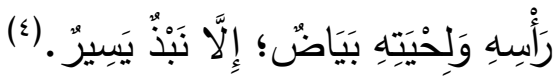

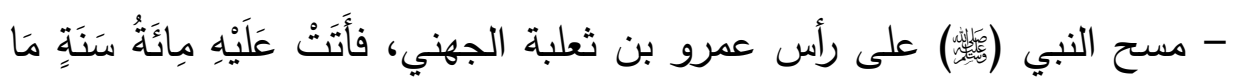

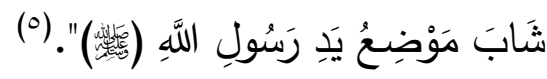

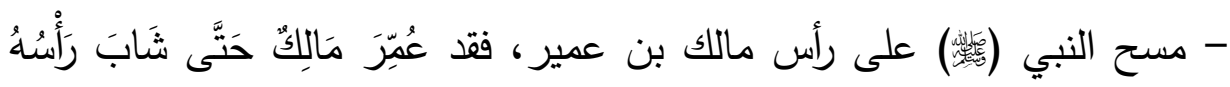

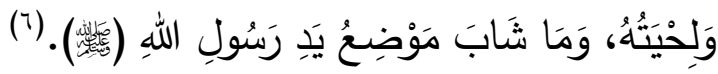

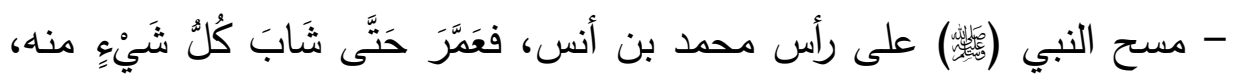

(1) سبق تخريجه والحكم عليه في ترجمة رقم (1).

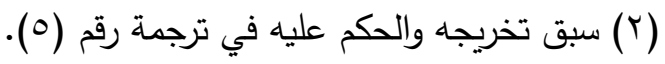

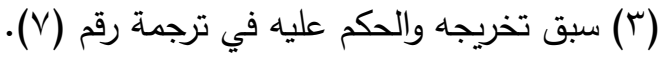

(§) سبق تخريجه والحكم عليه في ترجمة رقم (1) (1).

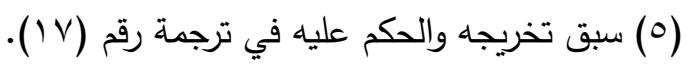

(T) سبق تخريجه والحكم عليه في ترجمة رقم (Y) (Y) (Y) 


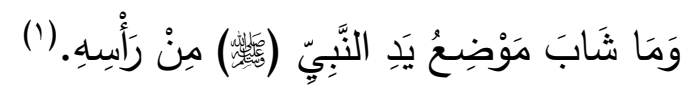

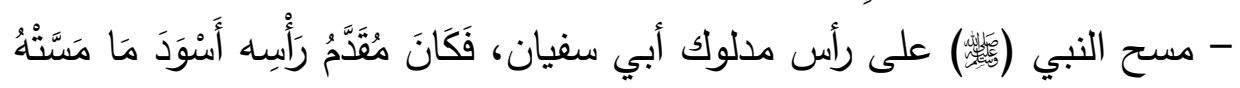

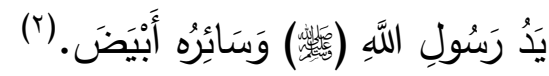

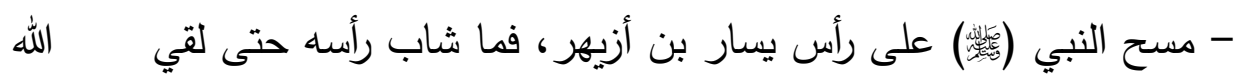
(r). (نَ)

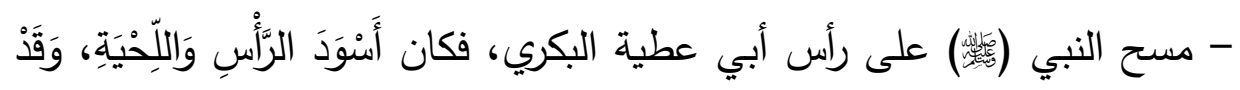

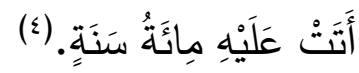
r- حصول إنبات الشعر بمستح النبي (赔) على رأس للأقرع:

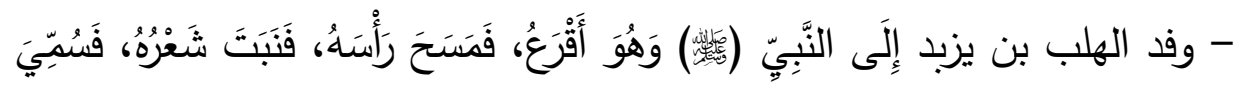
الْهُلْب. (ن)

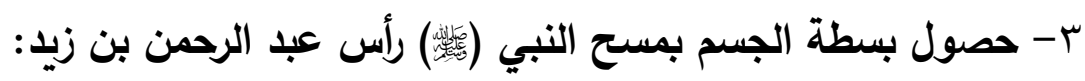
- فما رؤي مولود قط أصغر خلقة من عبد الرحمن بن زيد بن الخطاب، فحين

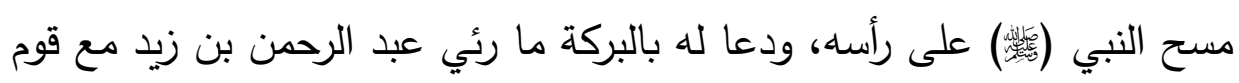
في صف إلا نزعهم طولا. (؟)

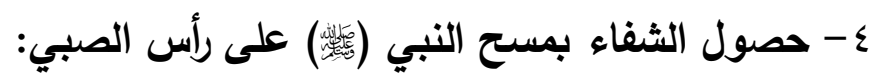
- قيام السائب بن يزيد وكأن ما به من وجع حين ذهبت خالة السائب بن يزيد به

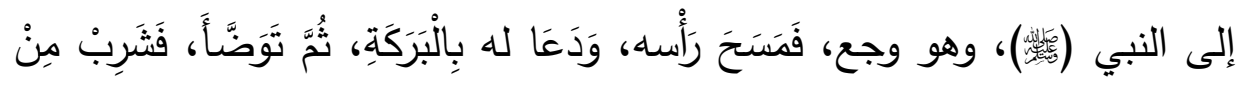

$$
\begin{aligned}
& \text { (1) سبق تخريجه والحكم عليه في ترجمة رقم (Y (Y). }
\end{aligned}
$$

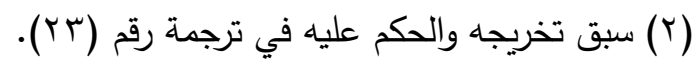

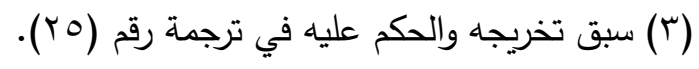

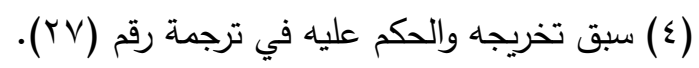

$$
\begin{aligned}
& \text { (0) سبق تخريجه والحكم عليه في ترجمة رقم (؟Y). } \\
& \text { (ך) سبق تخريجه والحكم عليه في ترجمة رقم (^). }
\end{aligned}
$$




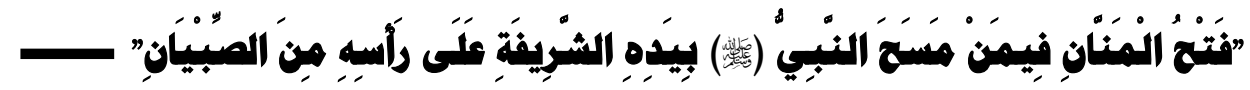

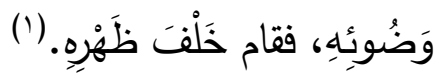

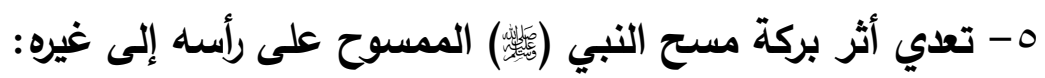

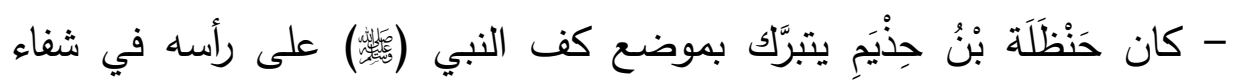

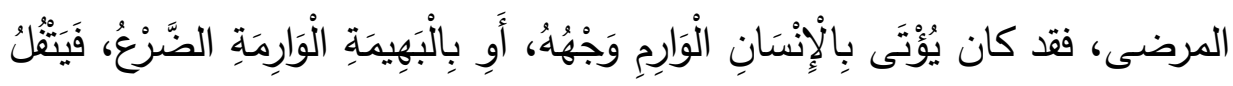

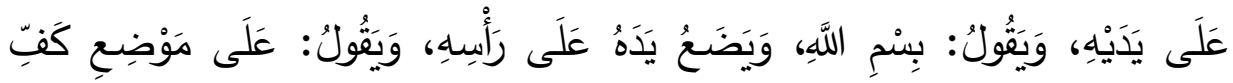

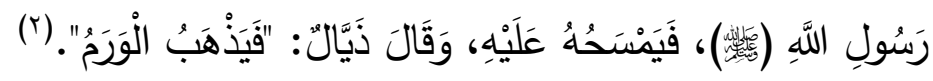

\section{الالطاب الثاني}

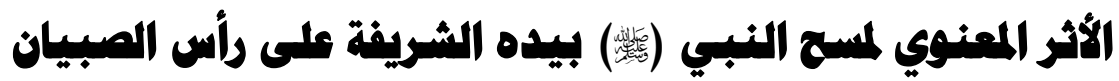

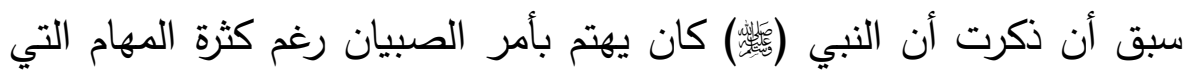

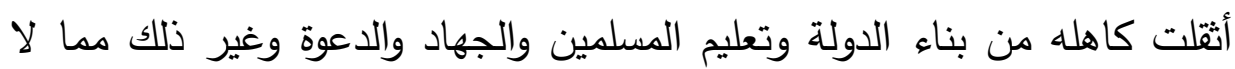

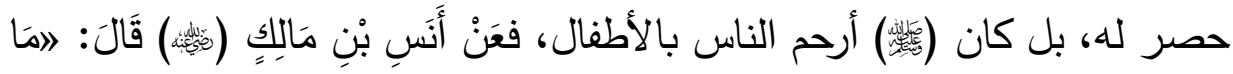

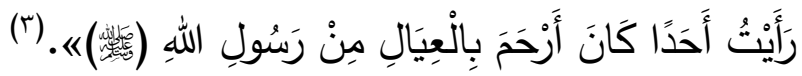

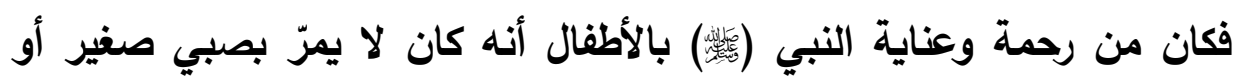

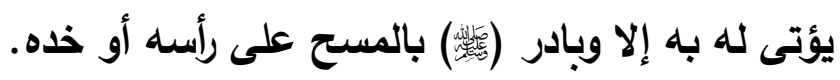

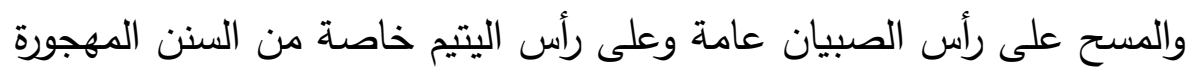

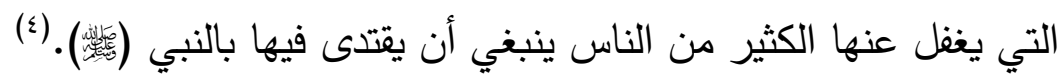

$$
\begin{aligned}
& \text { ( (1) سبق تخريجه والحكم عليه في ترجمة رقم (0). } \\
& \text { (r) سبق تخريجه والدكم عليه في ترجمة رقم (r) (r). }
\end{aligned}
$$

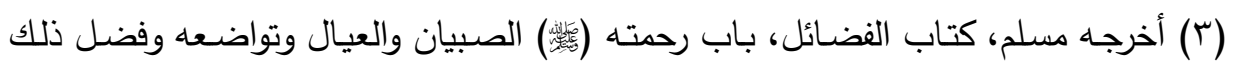

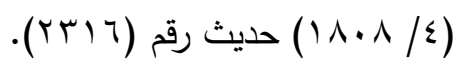

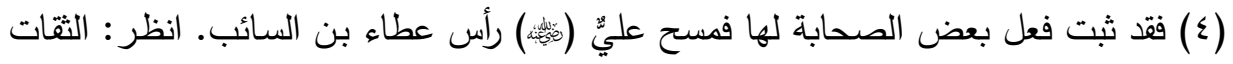

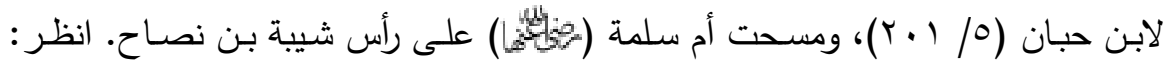

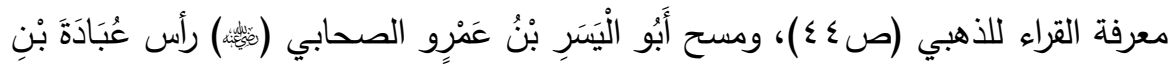




\section{مجلح كلية اصول الدين والدعوة بالموفية العدد التاسع والثلاثون}

وفي فعله (敞) ذلك أعظم الأسوة لنا، فينبغي الاقتداء به في رحمته صغار

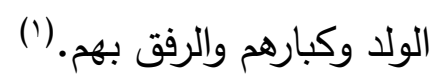

فالرحمة بالولا الصغير ، ومعانقته، وتتبيله، والرفق بله، والمسح على رأسه،

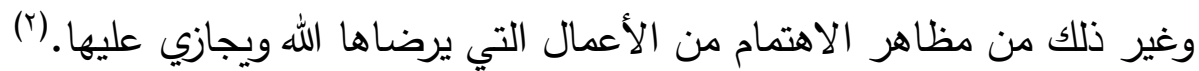

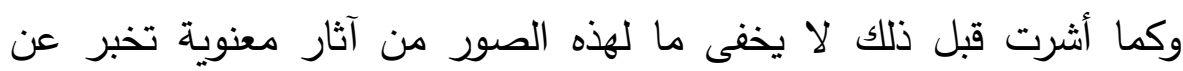
معاني الحب والعطف والرحمة، والصبي بأمسّ الحاجة لهذه المظاهر التي تعطي له الأمن والطمأنينة والاستقرار النفسي. وفي حرص النبي (لَّ المسح من أثر طيب في تربية وصلاح نفوس أطفالنا، وهو من الأسباب القوية في تهذيب سلوكياتهم، وكذلك في المسح على الرأس تكريم لصاحبه وشفقة عليه ومحبة له وجبر لخاطره.

ولعل الحكمة في تخصيص الرأس بالمسح عليها أن فيها الجهاز العصبي الذي يحوي معظم حواسه. ولا يزال العلم الحديث يحاول سبر بعض أسرار الهدي النبوي، ويكتشف بين الحين

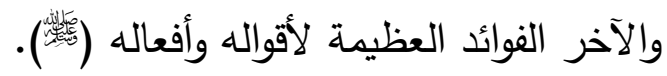

ومن هنا لا بد من اعتناء الدراسات الحديثة النفسية والسلوكية بدراسة أهمية المسح المباشر على رأس الأطفال وآثاره الإيجابية في الصحة النفسية والعقلية والبدنية، ولعلها دعوة لعلماء التربية والاجتماع والنفس أن يفسروا لنا في دراسة

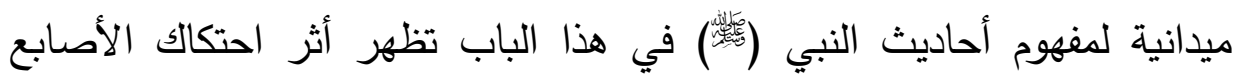

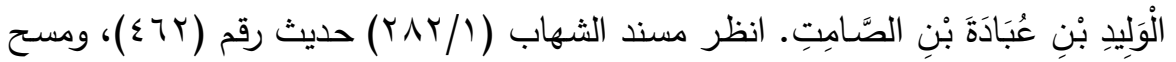

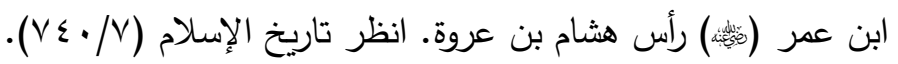

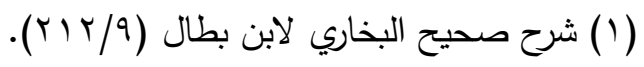

$$
\begin{aligned}
& \text { (Y) شرح صحيح البخاري لابن بطال (Y)/ (Y) (Y). }
\end{aligned}
$$




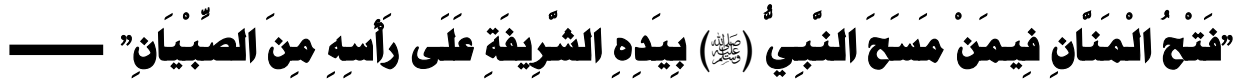

بثعر رأس الصغير نفسيا عليه.

فربما تثبت لنا هذه الدراسات ما للمسح على رأس الصبي من الفوائد التربوية العديدة على نفسية الأطفال فيشعرون بها ويستجييون لها ويحسون براحة نفسية على أثرها، وربما يوصى به كعلاج لبعض الحالات والمواقف.

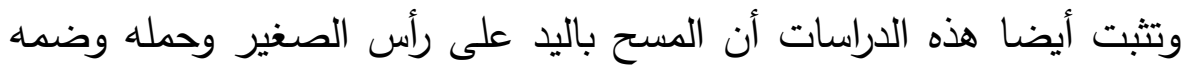

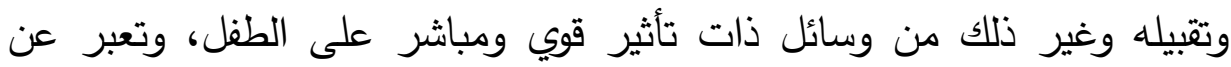
العاطفة والحب والاهتمام، ومن هنا تأتي أهميتها في العناية بالطفل ورعايته على ونى

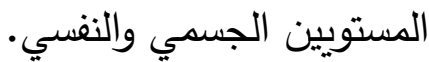
فالواقع يخبر أن حرمان الطفل من هذه الأشياء يؤدي إلى تأثيرات سلبية

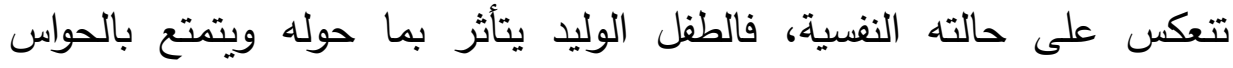

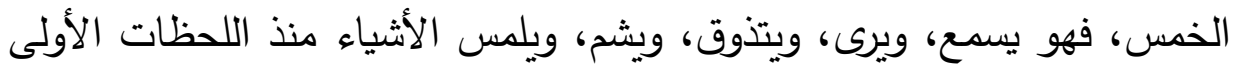

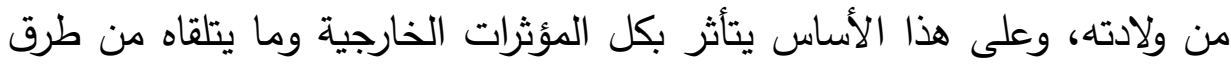
معاملته من أبويه والبيئة المحيطة به إيجابا وسلبا. وتزداد حاجة الأطفال الصغار إلى المسح على رؤوسهم في حالة قلقهم أو الوسليا.

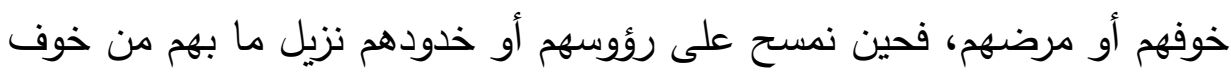

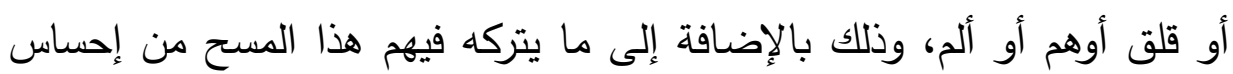

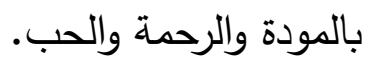

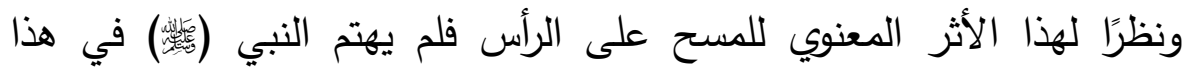

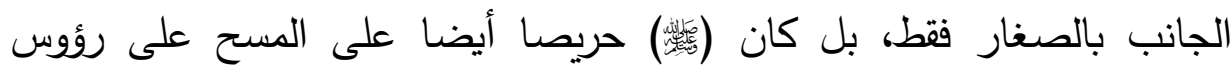

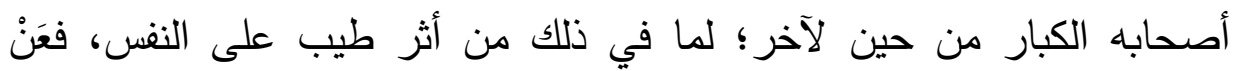

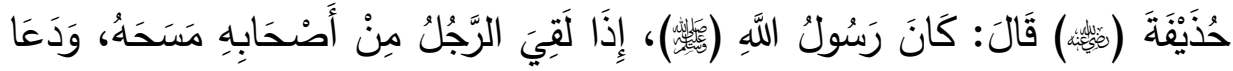

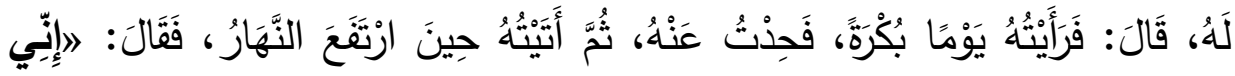




\section{مجلل كلية اصول الدين والدعوة بالمنوفية العدد التاسع والثلاثثون}

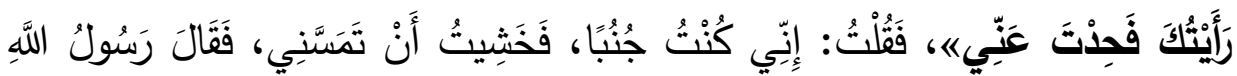

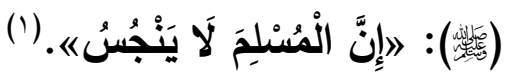
وتتأكد حاجة الأطفال أكثر إلى هذه المعاني في حالة فقدان أبويه أو أحدهما، وهذا يفسر ما جاء عن النبي (瀻) في المسح على رأس اليتيم قولا وفعلا؛ لما في المسح على الرأس من أثر طيب يعود على الطفل اليتيم، وينعكس على الماسح

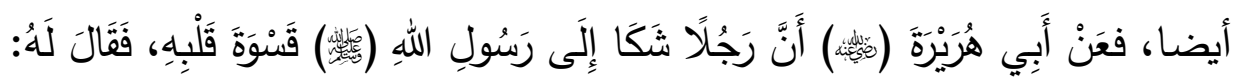

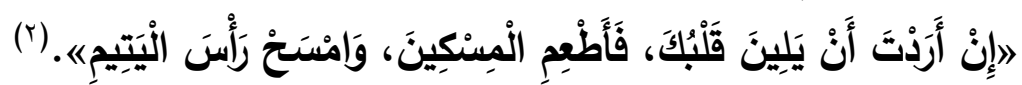

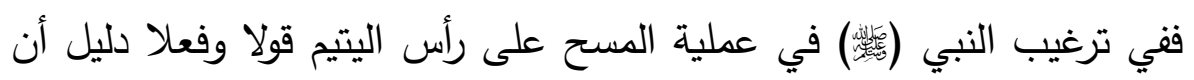
هذا الفعل البسيط في وصفه كبير في أثره على الماسح والممسوح، ونحن في حاجة ماسة إلى هذا الأثر في معالجة أمراض القلوب للطرفين، فالمرء في جميع مراحل حياته يتعرض لكثير من الأمور التي تُعرض قلبه إلى قسوة، مما يجعله في حاجة ماسة إلى وسائل متعددة ترجع القلب إلى ما كان عليه من اللين والصفاء. وربما تساعدنا الدراسات النفسية أيضا في إبراز أثر المسح على الرأس لكل من اليتيم ومن مسح على رأسه، وتقسير سر لين القلب.

(1 ) أخرجه ابن حبان في صحيحه، واللفظ له، كتاب الطهارة، ذكر الإخبار بأن المسلم إذا كان

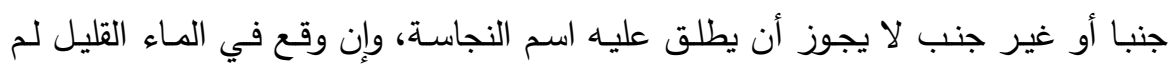

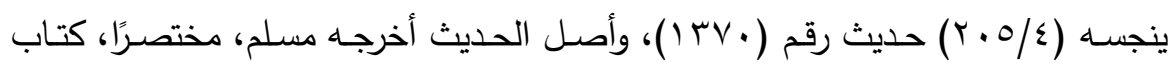

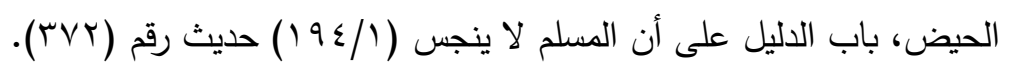

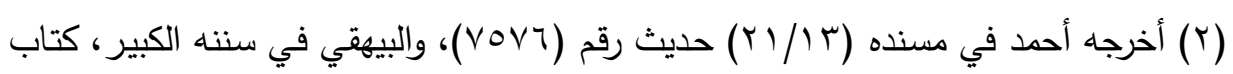

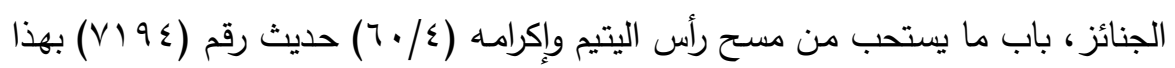

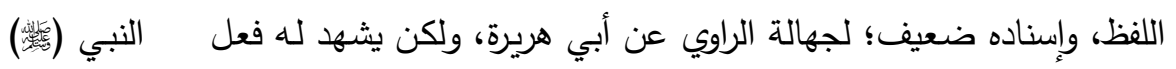
في مسحه على رأس اليتيم. 


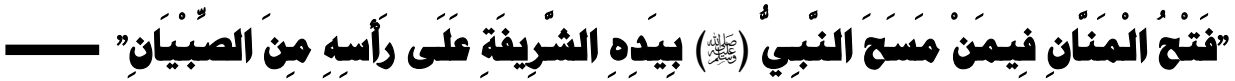

وقد أشارت الدكتورة مها يوسف جار الله في بحثها "المسح على رأس اليتيم" إلى أنه في دراسة على الأيتام في الحرب العالمية الثانية أجريت على الأطفال الرضع الأيتام الذين يتم لمسهم من قبل الممرضات والمعتتيات مقارنة بالأطفال الذين تتوفر لهم نفس ظروف الغذاء والملبس والعناية الطبية ولكن بدون لهس، وجدت هذه الدراسة أن الطفل الذي يلمس مقارنة بالطفل الذي لا يلمس يزيد وزنه

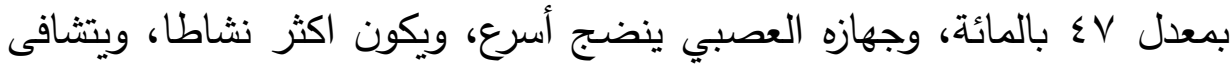
من الأمراض والالتهابات أسرع، وبعد أن يكبر قليلاً تكون نتائج الاختبارات العقلية ونكاني والنفسية عنده أفضل.

وقد تمت هذه الدراسة السابقة بعد ملاحظة واضحة على جناحين للأطفال

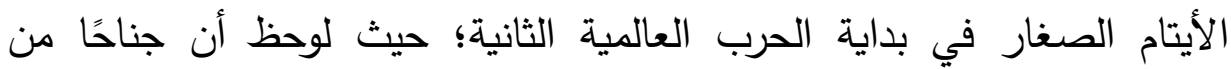

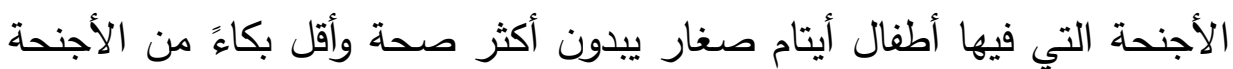

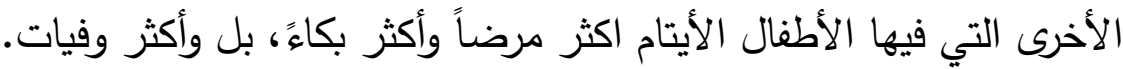

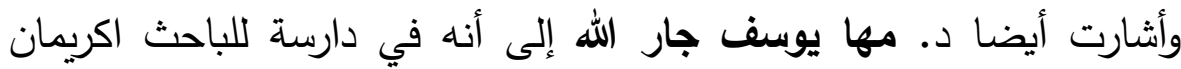
(ackerman 1991) وجد أن الطفل الذي يحصل على مسح جيد من قبل أفراد النهاد

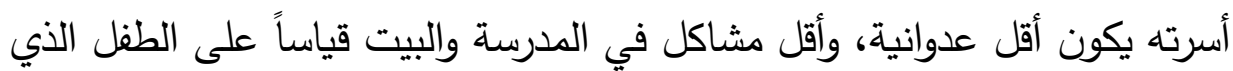
لا يحصل على لمس والديه. (1)

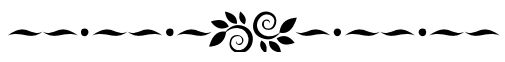

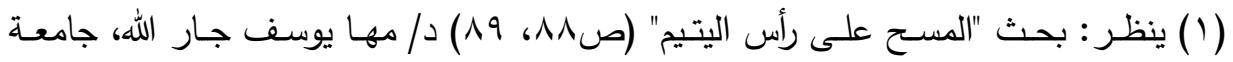
الكويت-كلية الثريعة والدراسات الإسلامية قسم التفسير والحديث-المؤتمر العلمي العاشر لـ للإعجاز العلمي في القرآن والسنة. 


\section{مجلح كليح اصول الدين والدعوة بالمنوفية العدد التاسع والثلاثثون}

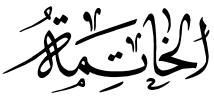

أتى هذا البحث بعنوان "فتح المنان فيمن مستح التبي (管) بيده الشريفة على رأسده من الصبيان"، وقد خلصت فيه إلى النتائج التالية: 1- اهتمت كتب السنة برصد اعتتاء النبي (先) بأمته عامة وبالضعفاء خاصة من الثيوخ والنساء والأطفال رغم كثرة شواغله.

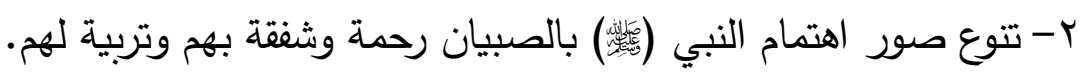

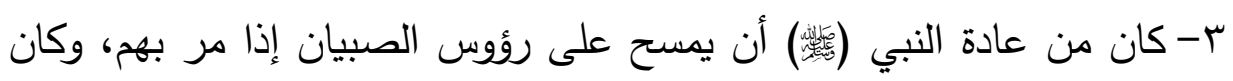

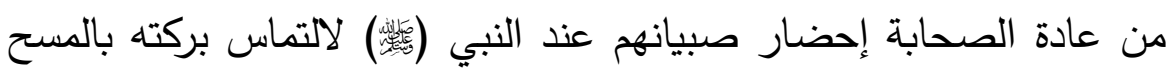

$$
\text { بيده الشريفة على رؤوسهم. }
$$

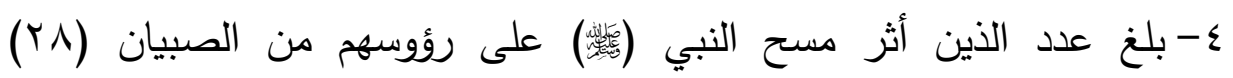
صحابيًا.

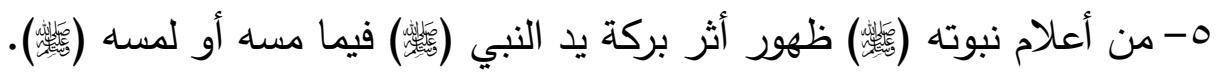
ج- تنوع الأثر الحسي والمعنوي لمسح النبي (赔) على رؤوس الصبيان. V- المسح على رأس الصغير عامة وعلى رأس اليتيم خاصة من السنن المهجورة التي ينبغي إحياؤها؛ لما له من أثر طيب على الماسح والممسوح في علاج

$$
\text { أمراض القلوب للطرفين. }
$$

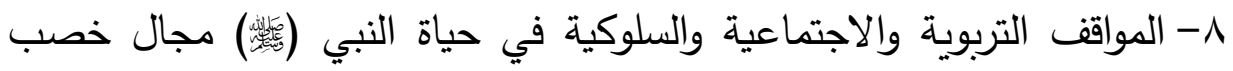
لمزيد من الدراسات المتخصصة لاستتباط ما بها من فوائد والعمل على تطبيقها. 9- إهمال مظاهر العناية بالأطفال في الواقع المعاصر له تأثيرات سلبية عليهم في الجوانب النفسية والاجتماعية. ويوصي الباحث بما يلي: 


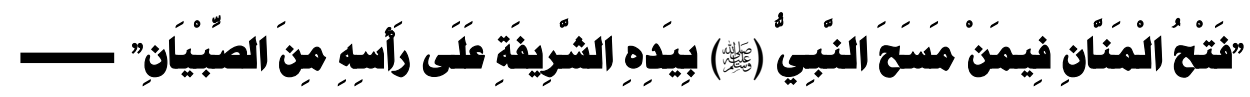
1- الاهتمام بالدراسات الإسلامية المتعلقة بالمنهج النبوي بالمقارنة مع المناهج

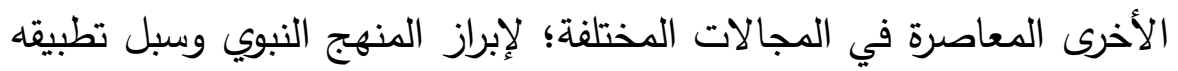

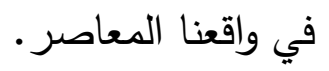

ץ- الاعتناء بالدراسات النفسية والاجتماعية والميدانية لكافة المواقف التربوية

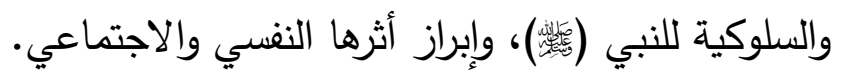

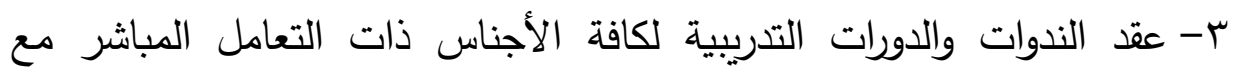
الأطفال لبيان وسائل التعامل معهم في ضوء التئ القرآن الكريم والسنة النبوية.

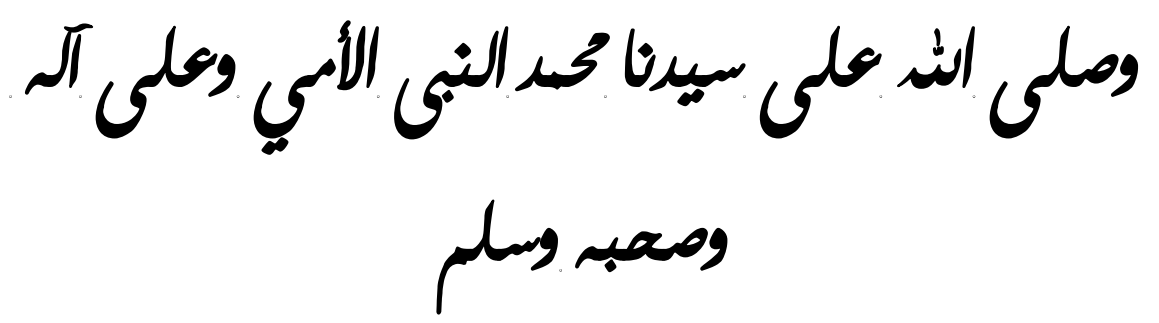

……ำ.ㄹ....... 


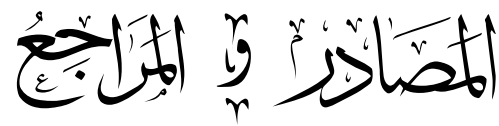

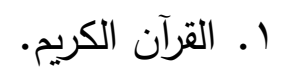

r. الآحاد والمثاني: لأبي بكر بن أبي عاصم وهو أحمد بن عمرو بن الضحاك

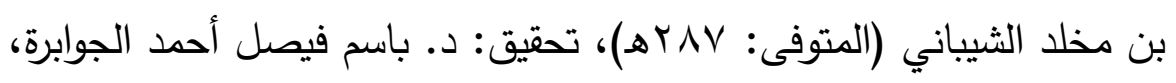

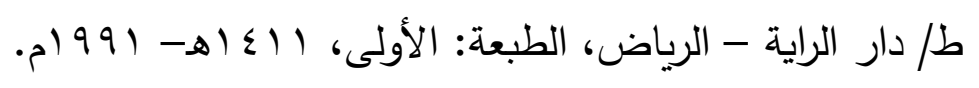

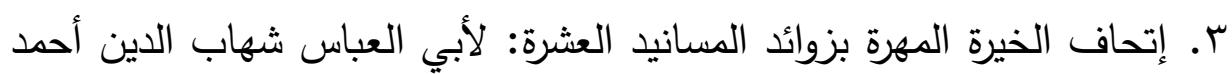

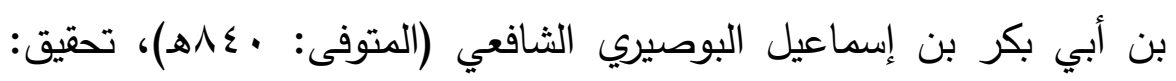

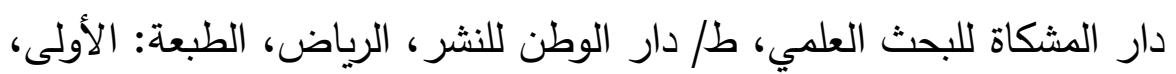

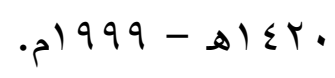

ـ. أخبار مكة في قديم الدهر وحديثه: لأبي عبد الله محمد بن إسحاق بن العباس

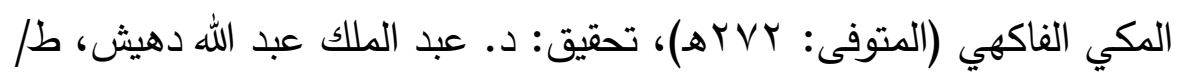

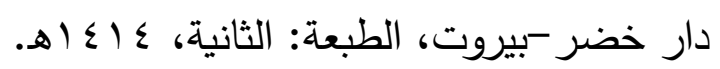

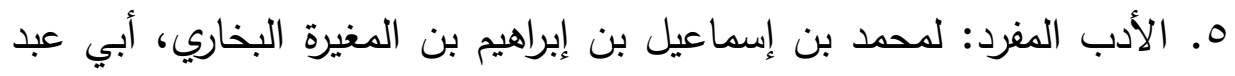

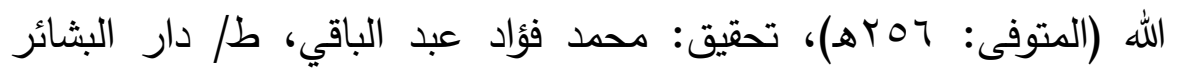

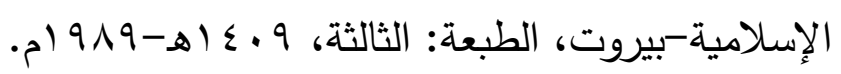

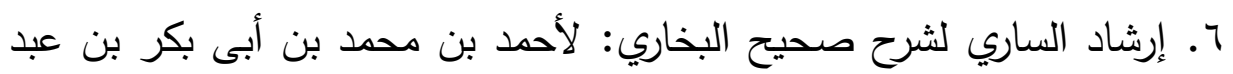

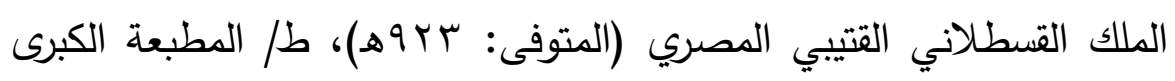

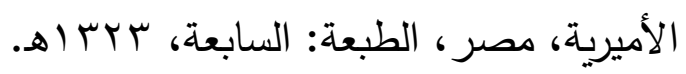

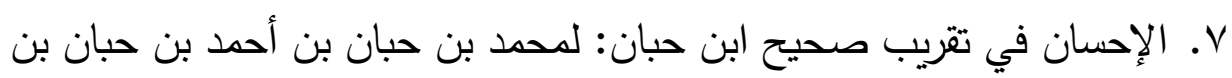

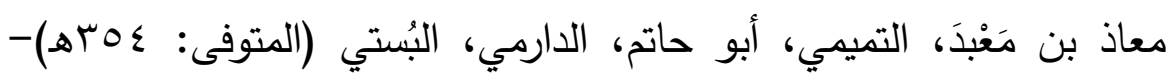

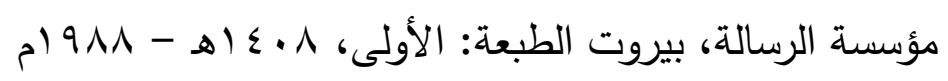




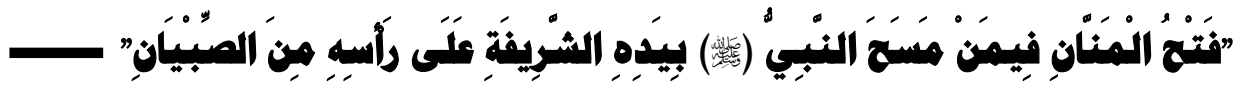

^. الاستيعاب في معرفة الأصحاب: لأبي عمر يوسف بن عبد الله بن محمد بن

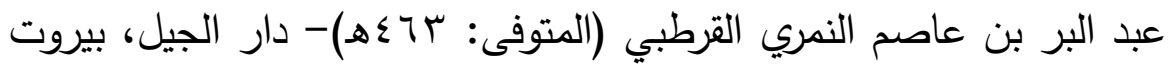

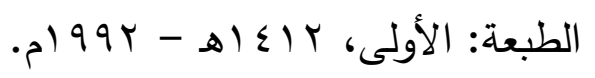

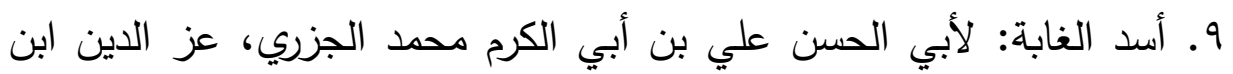

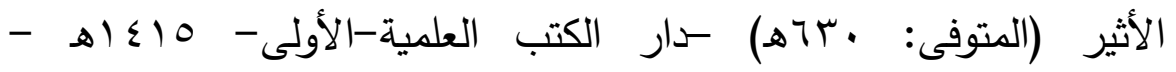

$.0199 \varepsilon$

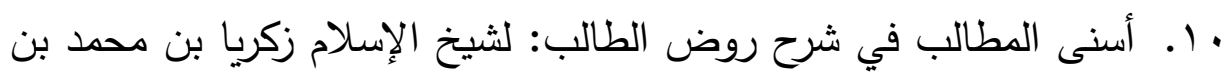

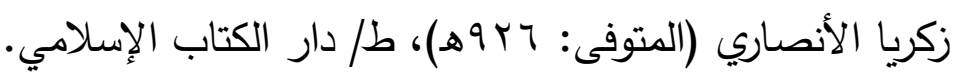

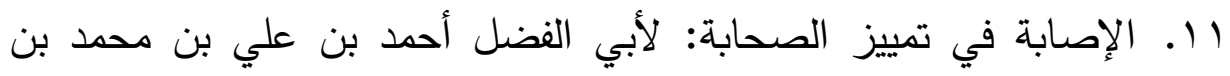

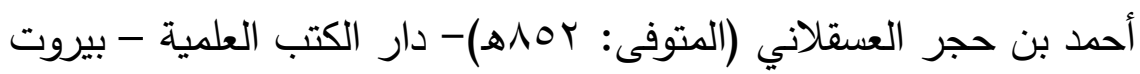

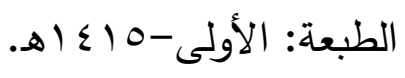

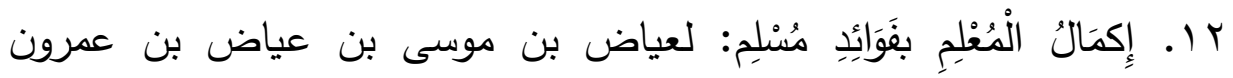

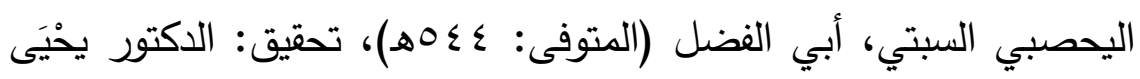

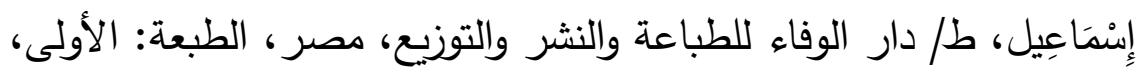

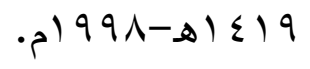

rا. الإكمال في رفع الارتياب عن المؤتلف والمختلف في الأسماء والكنى

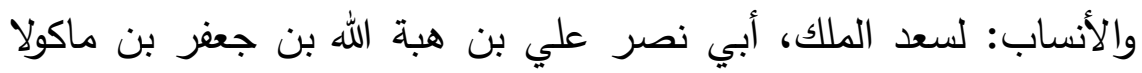

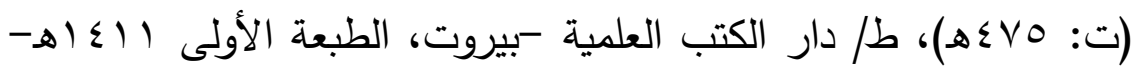
. 199 . ع ا. الإمتاع بالأربعين المتباينة السماع: لأبي الفضل أحمد بن علي بن محمد

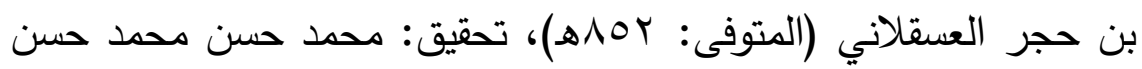




\section{مجلل كلية اصول الدين والدعوة بالمنوفية العدد التاسع والثلاثثون}

إسماعيل، ط/ دار الكتب العلمية-بيروت، الطبعة: الأولى، 1ـأهـ . $) 99 \mathrm{~V}$

1 . الإنصاف في معرفة الراجح من الخلاف: لعلاء الدين أبي الحسن علي بن

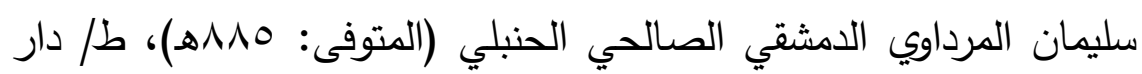

$$
\text { إحياء التراث العربي. }
$$

7 1. الأوسط في السنن والإجماع والاختلاف: لأبي بكر محمد بن إبراهيم بن المنذر النيسابوري (المتوفى: 9 ابهـ)، تحقيق: أبي حماد صغير أحمد بن محمد حنيف، ط/ دار طيبة - الرياض، الطبعة: الأولى - 0 ــ اله،

$$
\text { . }) 910
$$

V ا. . بغية الباحث عن زوائد مسند الحارث بن أبي أسامة: لنور الدين الهيثمي -

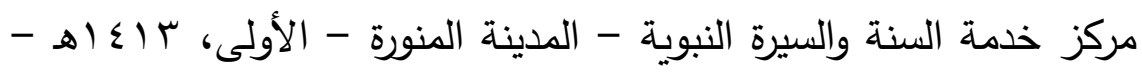

$$
\text { . } 99 \mathrm{r}
$$

1 ا. بيان الوهم والإيهام في كتاب الأحكام: لعلي بن محمد بن عبد الملك أم الكتامي الحميري الفاسي، أبي الحسن ابن القطان (المتوفى: ^ربآهـ) -

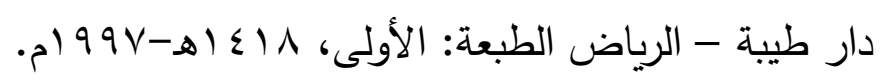

9 1. تاج العروس من جواهر القاموس: لمحمّد بن محمّد بن عبد الرزّاق

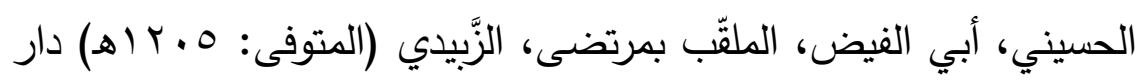

$$
\text { الهذاية. }
$$

• ·. تاريخ ابن معين رواية عثمان الدارمي: ليحيى بن معين، أبي زكريا - دار

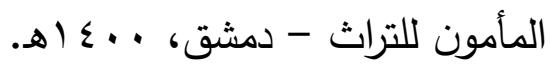

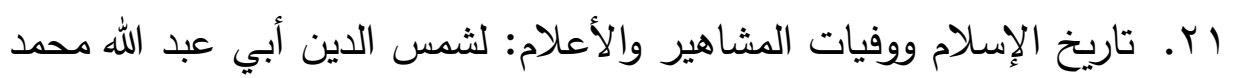
بن أحمد بن عثمان بن قَايْماز الذهبي (المتوفى: ^^ \هـ)، تحقيق: الدكتور

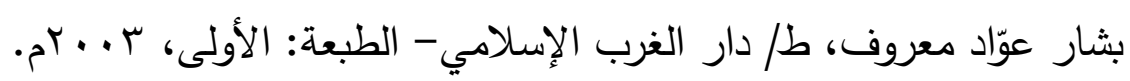




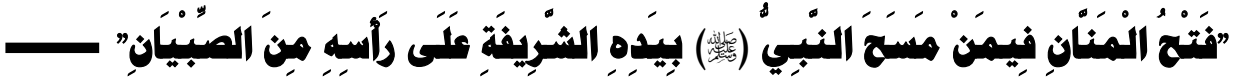

r. التاريخ الكبير : لمحمد بن إسماعيل البخاري (المتوفى: بهـهـ)، ط/ دائرة

$$
\text { المعارف العثمانية، حيدر آباد - الدكن. }
$$

سr. التاريخ الكبير المعروف بتاريخ ابن أبي خيثمة-السفر الثاني: لأبي بكر أحمد بن أبي خيثة (المتوفى:

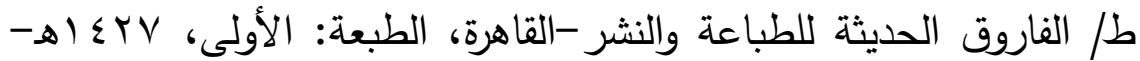

$$
\cdot 2 T \cdot 7
$$

ع r. تاريخ دمشق: لأبي القاسم علي بن الحسن بن هبة الله المعروف بابن عساكر (المتوفى: المهـ)- طار دار الفكر للطباعة والنشر والتوزيع

$$
\text { . } 1990-81 \leqslant 10
$$

ه . . التاريخ الأوسط: لمحمد بن إسماعيل بن إبراهيم بن المغيرة البخاري، أبي

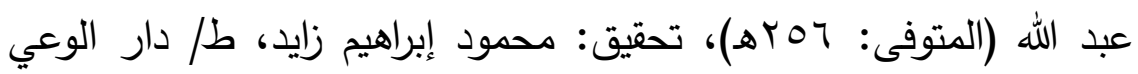

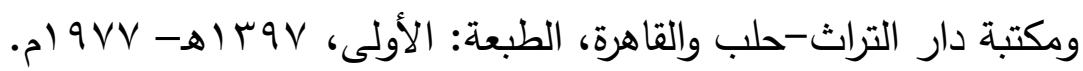
جr. تعجيل المنفعة بزوائد رجال الأئمة الأربعة: لأبي الفضل أحمد بن علي بن محمد بن أحمد بن حجر العسقلاني (المتوفى: بهorهـ، تحقيق: د. إكرام الله إمداد الحق، ط/ دار البشائر -بيروت، الطبعة: الأولى ـ 999 ام. V V تقريب التهذيب: لأبي الفضل أحمد بن علي بن محمد بن أحمد بن حجر العسقلاني (المتوفى: بهـهـ)- دار الرشيد - سوريا الطبعة: الأولى،

$$
\text { . } 9 \wedge 7-8) \leq \cdot 7
$$

^r. التلخيص الحبير في تخريج أحاديث الرافعي الكبير : لأبي الفضل أحمد بن علي بن محمد بن أحمد بن حجر العسقلاني (المتوفى: ب0rهـ)- مؤسسة

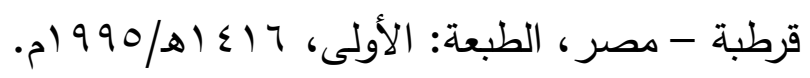




\section{مجلل كلية اصول الدين والدعوة بالمنوفية العدد التاسع والثلاثثون}

وץ. تهذيب الأسماء واللغات: لشيخ الإسلام أبي زكريا محيي الدين يحيى بن

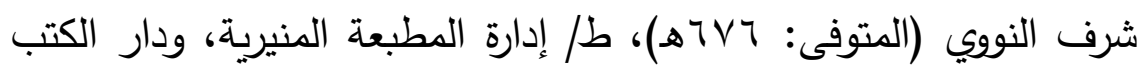

$$
\text { العلمية- بيروت. }
$$

• r. تهذيب التهذيب: لأبي الفضل أحمد بن علي بن محمد بن أحمد بن حجر العسقلاني (المتوفى: بهـهـ) - مطبعة دائرة المعارف النظامية، الهند

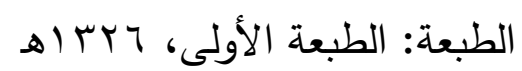

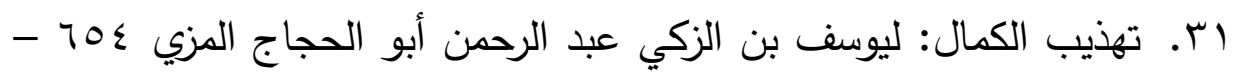

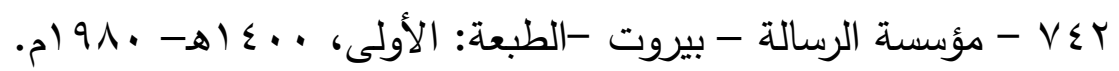

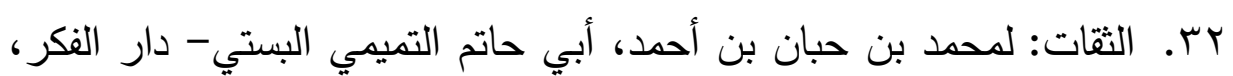

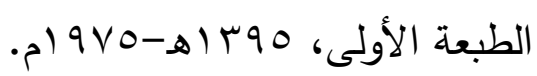

سب. الجرح والتعديل: لأبي محمد عبد الرحمن بن أبى حاتم محمد بن إدريس بن

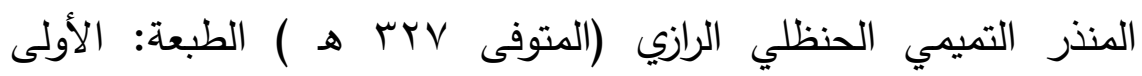
بمطبعة مجلس دائرة المعارف العثمانية - بحيدر آباد الدكن - الهند سنة

$$
\text { . } 90 r-8|r V|
$$

ع r. حلية الأولياء وطبقات الأصفياء: لأبي نعيم أحمد بن عبد الله بن أحمد بن

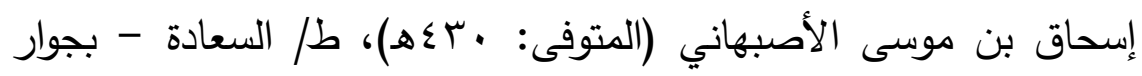

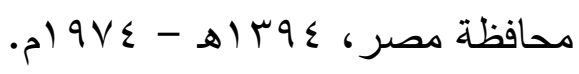

هـ. دلائل النبوة: لأحمد بن الحسين بن علي بن موسى الخراساني، أبي بكر

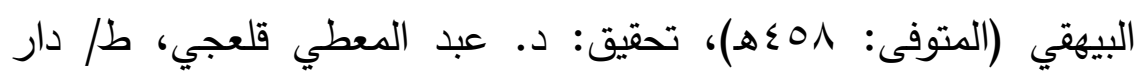

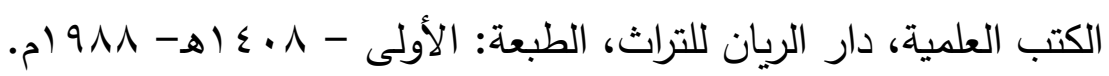
דب. دلائل النبوة: لإسماعيل بن محمد بن الفضل بن علي القرشي الطليحي التيمي الأصبهاني، أبي القاسم، الملب بقوام السنة (المتوفى: هبهـه)، 


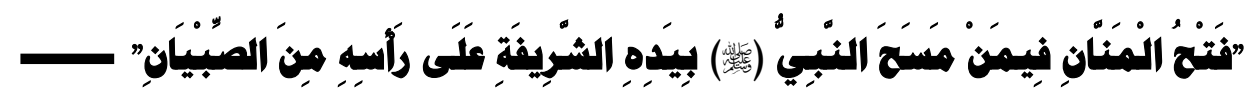

تحقيق: الدحقق: محمد محمد الحداد، ط/ دار طيبة - الرياض، الطبعة:

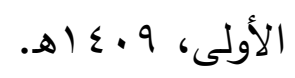

rV

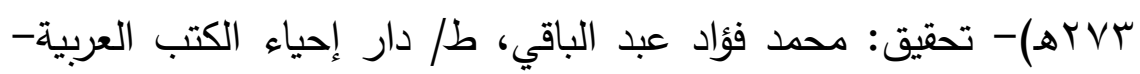
فيصل عيسى البابي الحلبي. ^r. سنن أبي داود: لأبي داود سليمان بن الأشعث السجستاني - طا دار

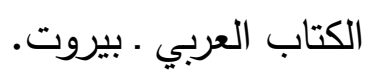

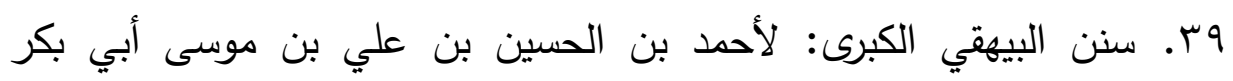

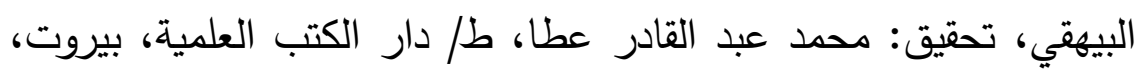

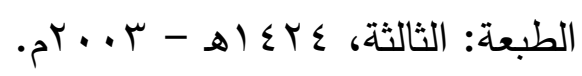
•ـ. سنن الترمذي: لمحمد بن عيسى أبي عيسى الترمذي- طاء دار إحياء

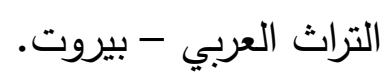

اء. سنن الدارقطني: لأبي الحسن علي بن عمر بن أحمد بن مهدي بن مسعود

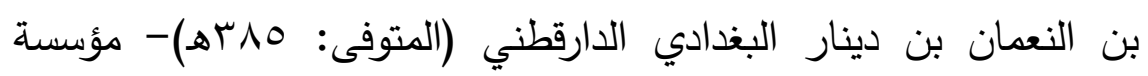

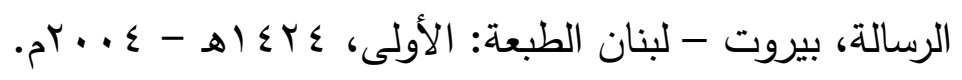

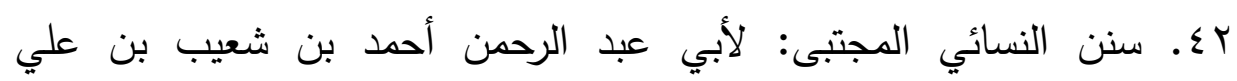

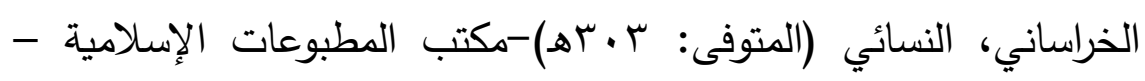

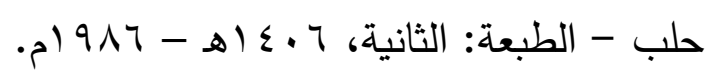

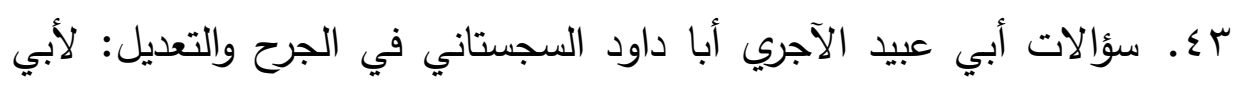

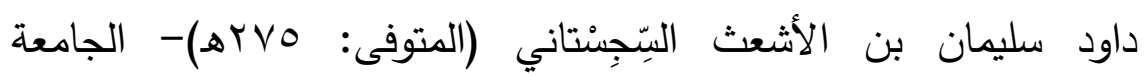

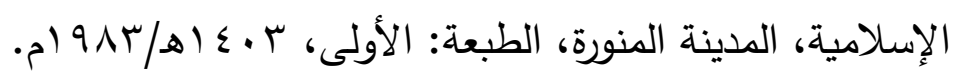




\section{مجلل كلية اصول الدين والدعوة بالمنوفية العدد التاسع والثلاثون}

ــ. سير أعلام النبلاء - للإمام شمس الدين محمد بن أحمد بن عثمان الذهبي

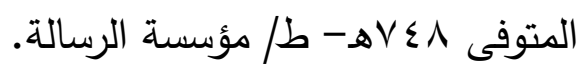

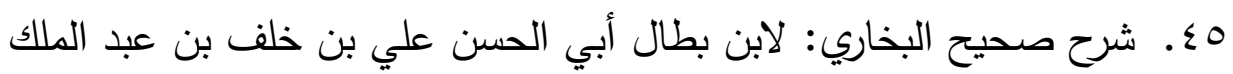
(المتوفى: 9؟ هـ)، تحقيق: أبي تميم ياسر بن إبراهيم، ط/ مكتبة الرشد-

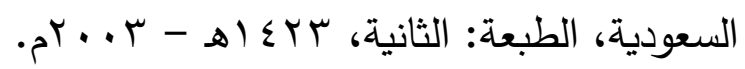

Tء. صحيح البخاري -الجامع الصحيح المختصر - محمد بن إسماعيل أبو عبد الله البخاري الجعفي- - -دار ابن كثير، اليمامة - بيروت - الطبعة

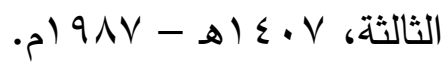

V V . الطبقات الكبرى: لأبي عبد الله محمد بن سعد بن منيع الهاشمي بالولاء،

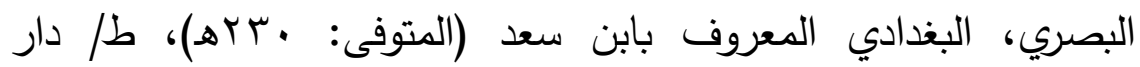

$$
\text { صادر -بيروت، الطبعة: الأولى، } 941 \text { ام. }
$$

1ـ. الطبقات الكبرى (الجزء المتمم لطبقات ابن سعد-الطبقة الرابعة من الصحابة ممن أسلم عند فتح مكة وما بعد ذلك): لأبي عبد الله محمد بن سعد بن منيع الهاشي (المتوفى: · بrهـ)، تحقيق ودراسة: الدكتور/ عبد العزيز عبد الله السلومي، طل مكتبة الصديق-الطائف، المملكة العربية

$$
\text { السعودية، طا/ } 7 \text { إع أهـ }
$$

9ء. الطبقات الكبرى (الجزء المتمم لطبقات ابن سعد-الطبقة الخامسة في من

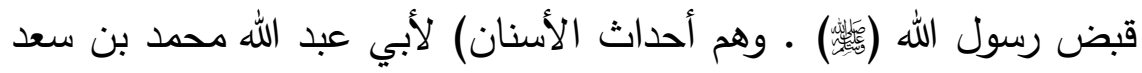
بن منيع الهاشمي بالولاء، البصري، البغدادي المعروف بابن سعد (المتوفى:

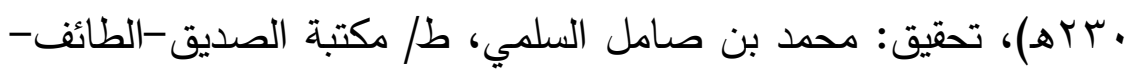

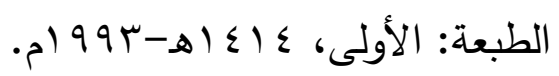




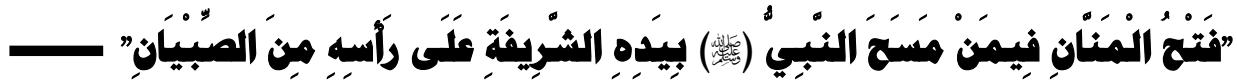

•. حيدر، أبي عبد الرحمن، شرف الحق، الصديقي، العظيم آبادي (المتوفى:

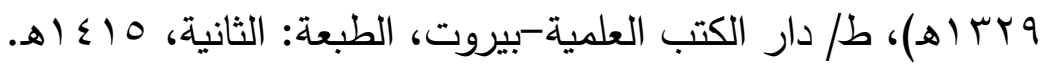

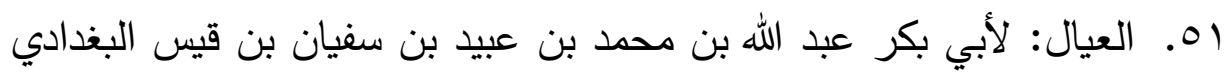

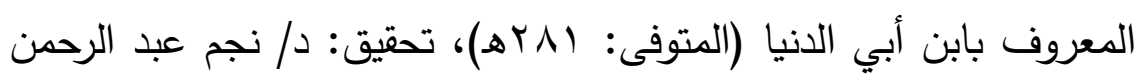

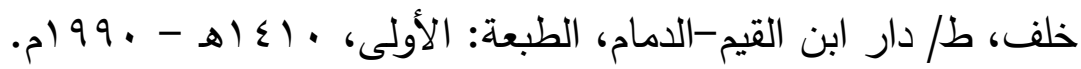

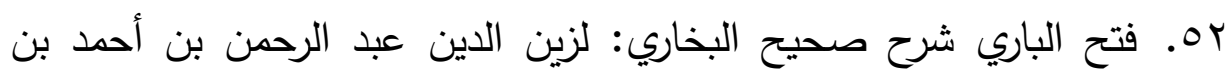

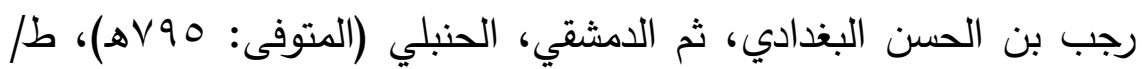

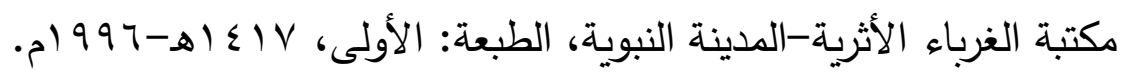

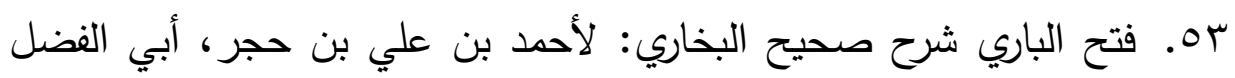

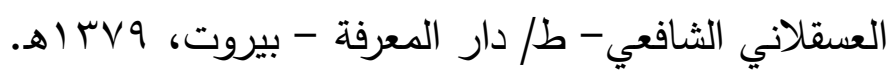

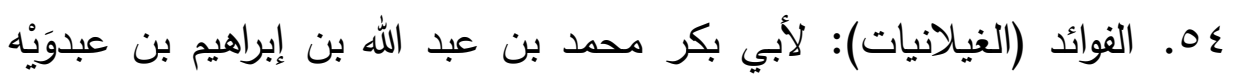

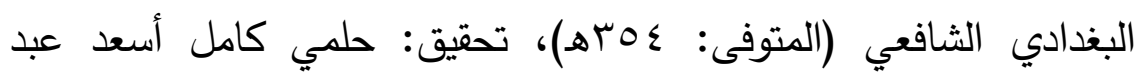

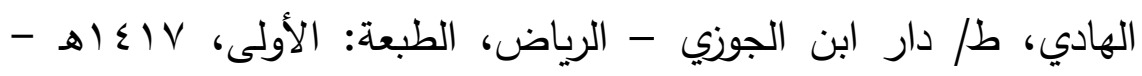
$.0199 \mathrm{~V}$

00. الكاشف في معرفة من له رواية في الكتب الستة: لثمس الدين أبي عبد الله

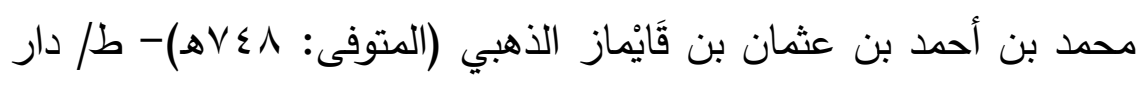

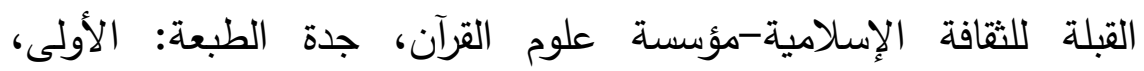

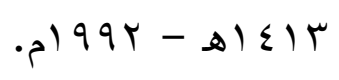

07. الكامل في ضعفاء الرجال: لأبي أحمد عبد الله بن عدي الجرجاني

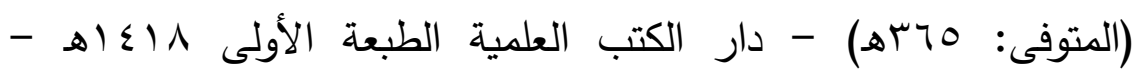
. $199 \mathrm{~V}$ 


\section{مجللح كليح اصول الدين والدعوة بالمنوفية العدد التاسع والثلاثون}

ov

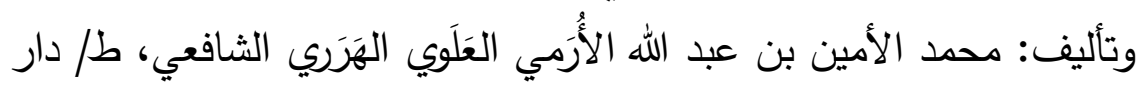

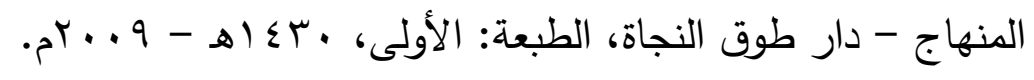

ه1. الكنى والأسماء: لأبي بِشْر محمد بن أحمد بن حماد بن سعيد بن مسلم

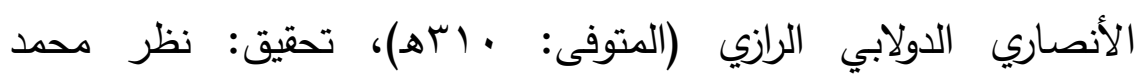

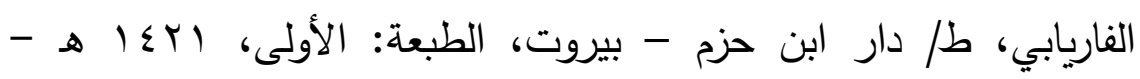
.

هو. اللباب في تهذيب الأنساب: لأبي الحسن علي بن أبي الكرم محمد بن محمد بن عبد الكريم بن عبد الواحد الثيباني الجزري، عز الدين ابن الأثير

$$
\text { (المتوفى: • بآهـ)، طا دار صادر - بيروت. }
$$

• 7. لسان العرب: لمحمد بن مكرم بن منظور الأفريقي المصري، ط/ دار صادر -بيروت- الطبعة الأولى.

آج. لسان الميزان: لأبي الفضل أحمد بن علي بن محمد بن أحمد بن حجر

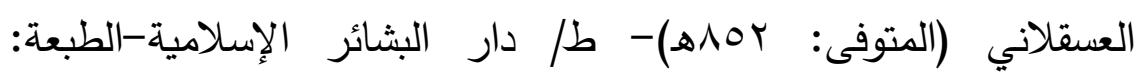

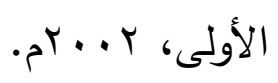

با7. المؤتَفِ والمختَفِف: لأبي الحسن علي بن عمر بن أحمد بن مهدي بن

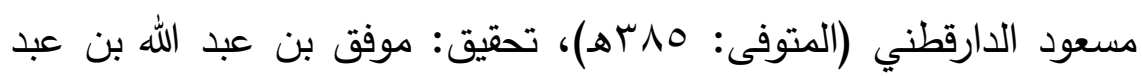

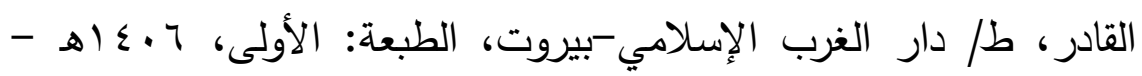
- $) 917$

سج. . مجمع الزوائد ومنبع الفوائد: لأبي الحسن نور الدين علي بن أبي بكر بن

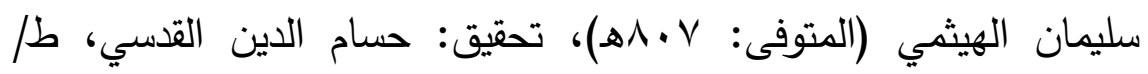

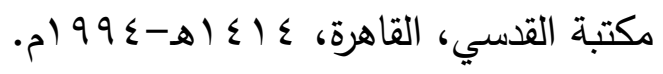




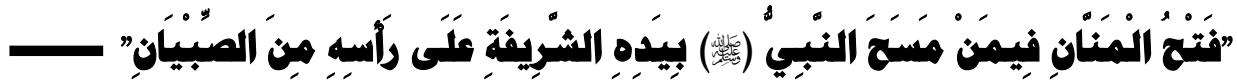

ع ا. مراصد الاطلاع على أسماء الأمكنة والبقاع: لعبد المؤمن بن عبد الحق، ابن شمائل القطيعي البغدادي، الحنبلي، صفيّ الدين (المتوفى: وسلهـ)،

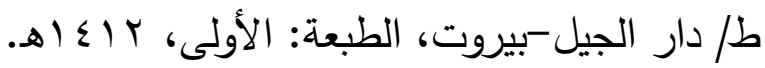

ه7. المستدرك على الصحيحين: لمحمد بن عبد الله، أبي عبد الله الحاكم

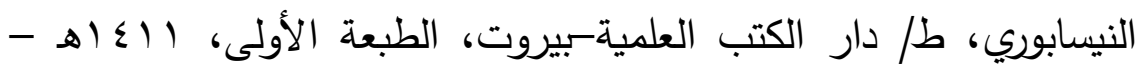
. $) 99$. ד7. المسح على رأس اليتيم": للدكتورة/ مها يوسف جار الله، جامعة الكويتكلية الشريعة والدراسات الإسلامية قسم التفسير والحديث-المؤتمر العلمي العاشر للإعجاز العلمي في القرآن والسنة. TV . . مسند الإمام أحمد بن حنبل: لأحمد بن حنبل، أبي عبد الله الشيباني، تحقيق: شعيب الأرنؤوط-عادل مرشد، وآخرون، طا/ مؤسسة الرسالة،

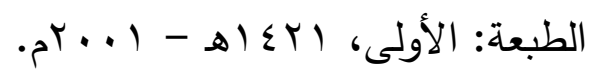

1 7. مسند ابن أبي شيبة: لأبي بكر بن أبي شيبة، عبد الله بن محمد بن إبراهيم بن عثمان العبسي (المتوفى:مبإهـ)، تحقيق: عادل بن يوسف العزازي، وأحمد بن فريد المزيدي، طا طار الوطن-الرياض، الطبعة: الأولى،

$$
\text { . }) 99 \mathrm{~V}
$$

9 79. مسند البزار (المطبوع باسم البحر الزخار): لأبي بكر أحمد بن عمرو بن عبد الخالق البزار المتوفى: بq ب هـ مكتبة العلوم والحكم - المدينة

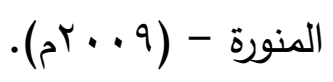

• . . مسند الروياني: لأبي بكر محمد بن هارون الرُّوياني (المتوفى: V• rهـ)، تحقيق: أيمن علي أبو يماني، طل مؤسسة قرطبة - القاهرة، الطبعة:

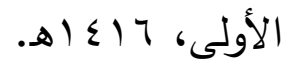




\section{مجلح كلية اصول الدين والدعوة بالموفية العدد التاسع والثلاثون}

V. مسند الثاميين: لسليمان بن أحمد بن أيوب بن مطير اللخمي الثامي، أبي القاسم الطبراني (المتوفى: · بسهـ)، تحقيق: حمدي بن عبد المجيد السلفي،

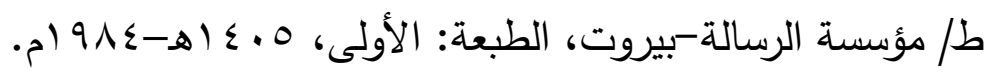

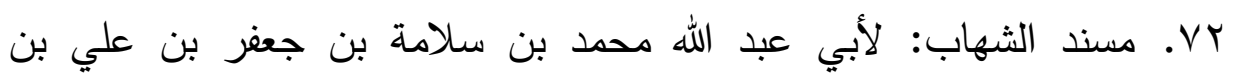

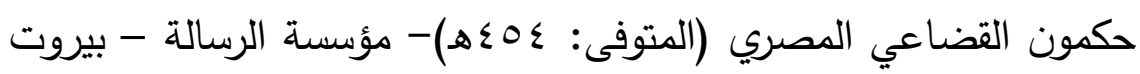

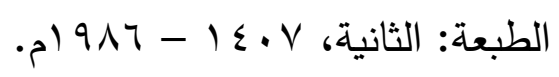

rV. المصباح المنير في غريب الشرح الكبير : لأحمد بن محمد بن علي الفيومي ثم الحموي، أبي العباس (المتوفى: نحو •VVه)، ط/ المكتبة العلميةبيروت.

ع V. مُصنف ابن أبي شيبة: لأبي بكر عبد الله بن محمد بن أبي شيبة

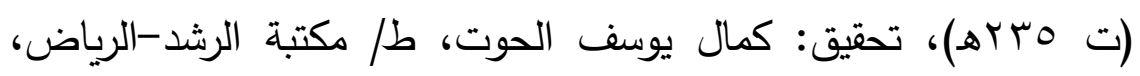

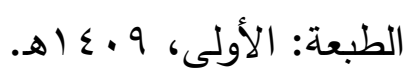

ه V. المعجم الأوسط: لأبي القاسم سليمان بن أحمد الطبراني- طا دار

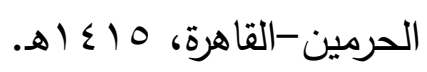

TV. معجم الصحابة: لأبي القاسم عبد الله بن محمد بن عبد العزيز بن المَرْزُبِان

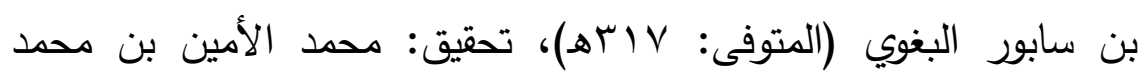

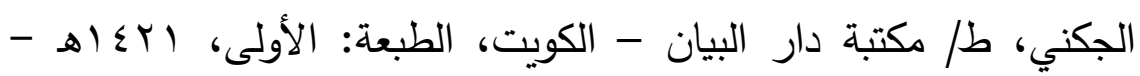

$$
\text { . }
$$

VV

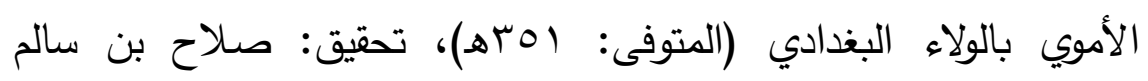

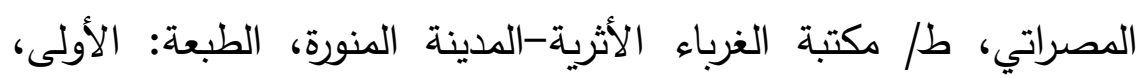




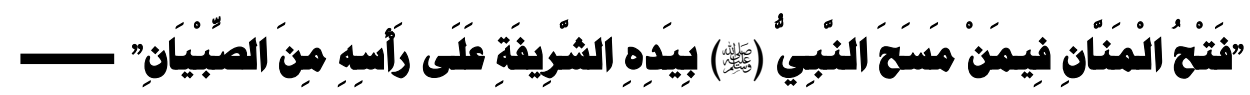
VA

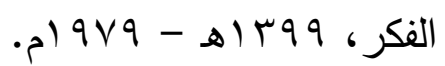

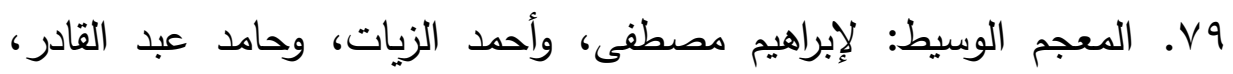

$$
\text { ومحمد النجار، ط/ دار الدعوة. }
$$

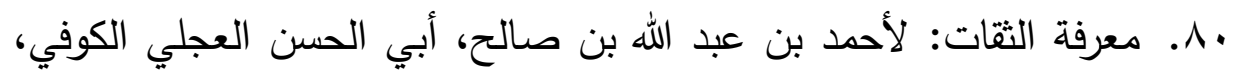

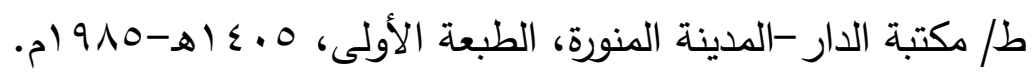

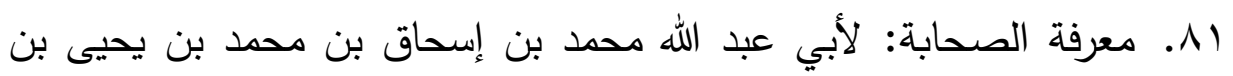

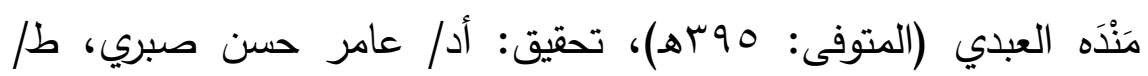

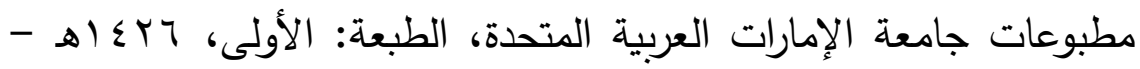

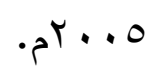

r.A. معرفة الصحابة: لأبي نعيم أحدد بن عبد الله بن أحمد بن إسحاق بن

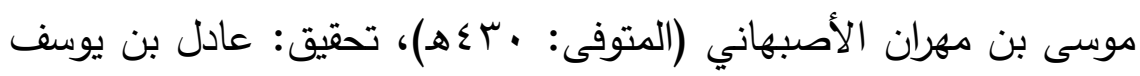

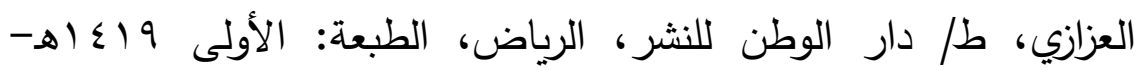
.

rی. معرفة القراء الكبار على الطبقات والأعصار: لثمس الدين أبو عبد الله

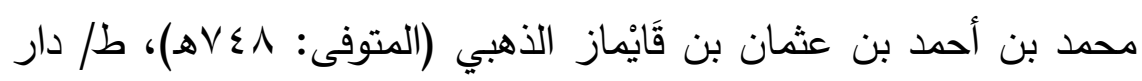

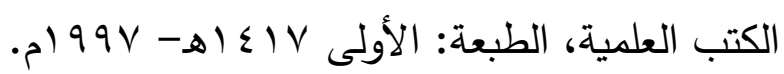

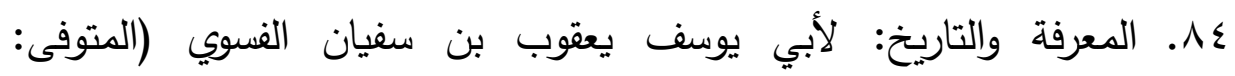

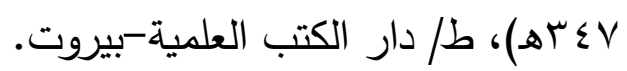

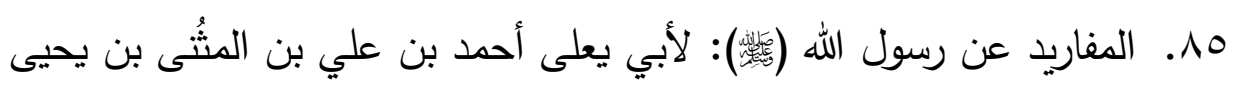

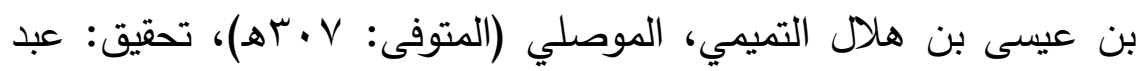




\section{مجلل كلية اصول الدين والدعوة بالمنوفية العدد التاسع والثلاثثون}

الله بن يوسف الجديع، ط/ مكتبة دار الأقصى -الكويت، الطبعة: الأولى، . () $\leqslant .0$

T1. المفردات في غربب القرآن: لأبي القاسم الحسين بن محمد المعروف بالراغب الأصفهانى (المتوفى: r •.0ه)، تحقيق: صفوان عدنان الداودي،

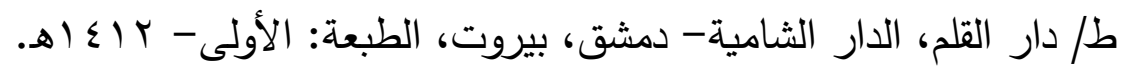
AV إبراهيم القرطبي (ت: 707 هـ)، ط/ دار ابن كثير، دمشق - بيروت، دار الكلم الطيب، دمشق - بيروت، الطبعة: الأولى، VI إهـ - 1997 ام. A^ــ المنتقى شرح الموطإ: لأبي الوليد سليمان بن خلف بن سعد بن أيوب بن بن

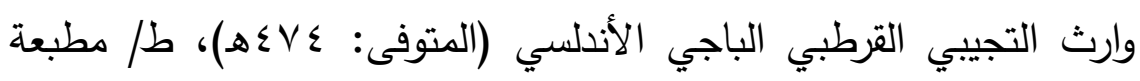

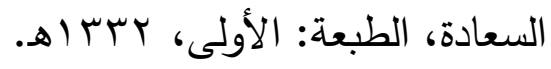

19. المنهاج شرح صحيح مسلم بن الحجاج: لشيخ الإسلام أبي زكريا محيي الدين يحيى بن شرف النووي (المتوفى: جآهـ)، طل دار إحياء التراث

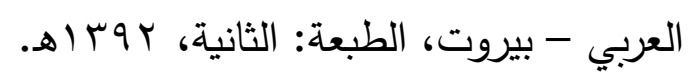

• 9. مواهب الجليل في شرح مختصر خليل: لشمس الدين أبي عبد الله محمد بن محمد بن عبد الرحمن الطرابلسي المغربي، المعروف بالحطاب الرُّعيني

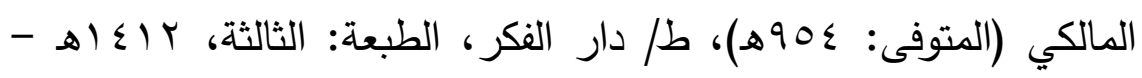
. 999 19. الموسوعة الفقهية الكويتية، صادر عن: وزارة الأوقاف والثئون الإسلامية-

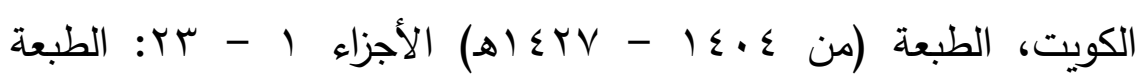
الثانية، ط/ دار السلاسل - الكويت. 


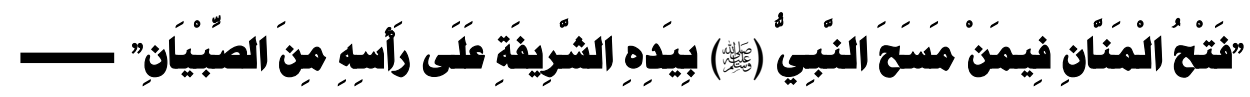

بو. ميزان الاعتدال في نقد الرجال: لثمس الدين أبي عبد الله محمد بن أحمد

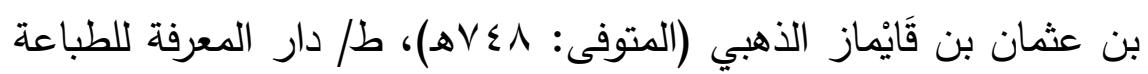

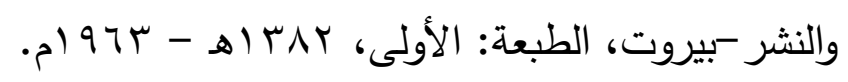

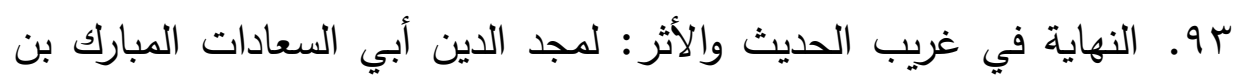

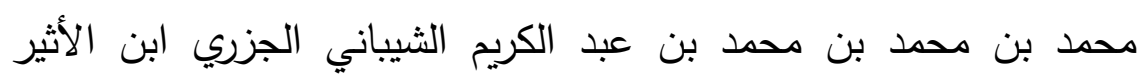

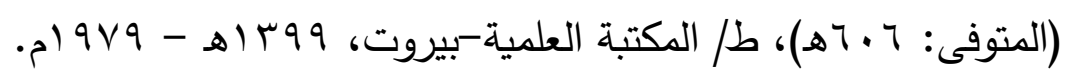

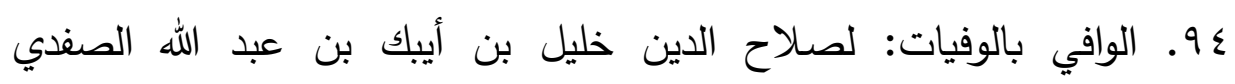

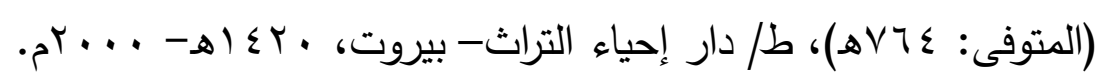
-ว̈ę-........ 


\section{مجلد كلية اصول الدين والدعوة بالمنوفية العدد التاسع والثثلاثون}

فهرس المتويات

\begin{tabular}{|c|c|}
\hline الهُهر رسر & الموضوع \\
\hline rq & الملخص العربي \\
\hline$\varepsilon$. & الملخص الإنجليزي \\
\hline$\varepsilon 1$ & المقدمة \\
\hline$\leqslant r$ & أسباب اختيار الموضوع \\
\hline$\varepsilon r$ & منهج البحث \\
\hline$\varepsilon r$ & خطة البحث \\
\hline$\varepsilon \varepsilon$ & 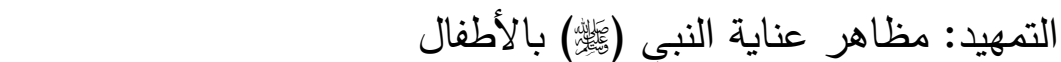 \\
\hline$\varepsilon \wedge$ & 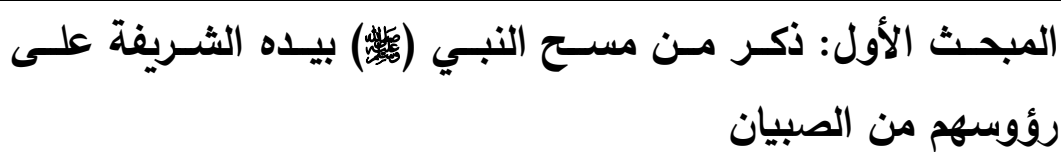 \\
\hline$\varepsilon q$ & 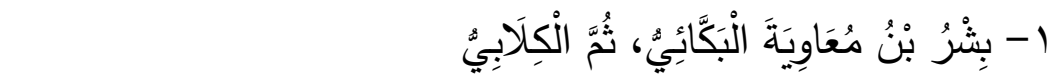 \\
\hline or & r- بَبِثيرُ بْنُ عَقْرَبَةَ الْجُهَنِيُّ \\
\hline 0$\}$ & ب- حَنْظَلَةُ بْنُ حِذْيَم بْنِ حَنِيفَةَ الْمَالِكِيُّ \\
\hline 07 & ع- رَافِعُ بْنُ عَمْرِو الْغِفَارِيٌّ \\
\hline$\Delta \wedge$ & ه- السَّائبُِ بْنُ يَزِيدَ الْكِنْدِيُّ \\
\hline 7. & 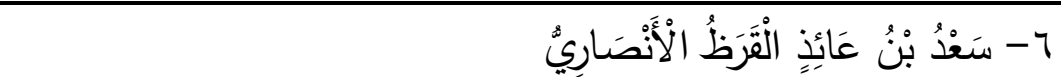 \\
\hline r & 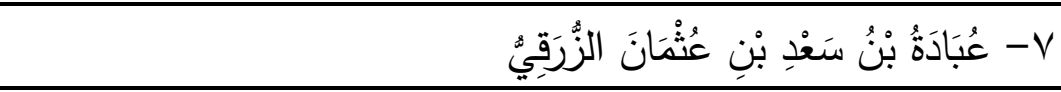 \\
\hline $7 \varepsilon$ & 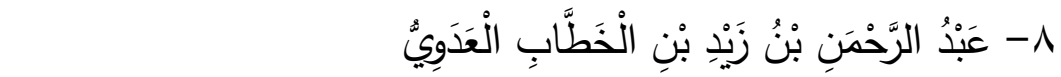 \\
\hline 70 & 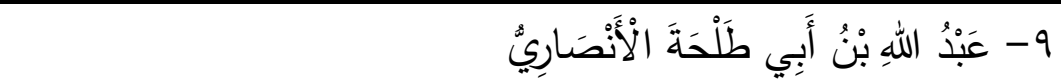 \\
\hline $7 \wedge$ & • ا - عَبُُْ اللهِ بْنُ بُسْرِ الْمَازِنِيُّ \\
\hline
\end{tabular}




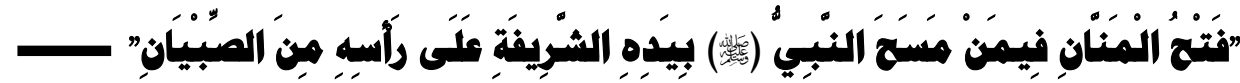

\begin{tabular}{|c|c|}
\hline v. & 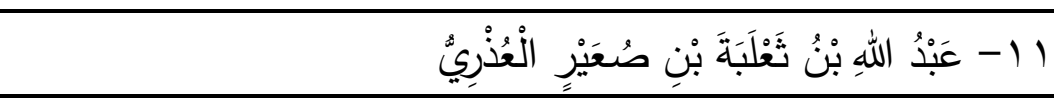 \\
\hline VI & 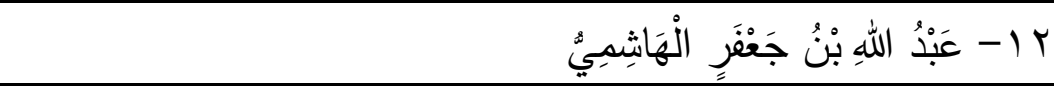 \\
\hline$V \mu$ & با \\
\hline vo & 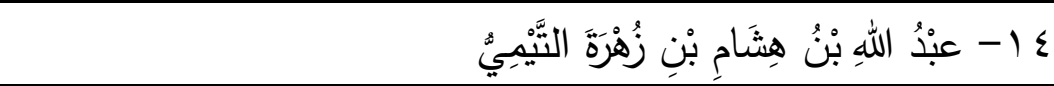 \\
\hline V4 & 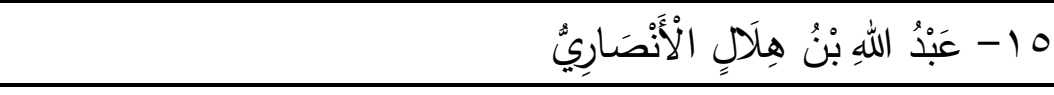 \\
\hline VV & 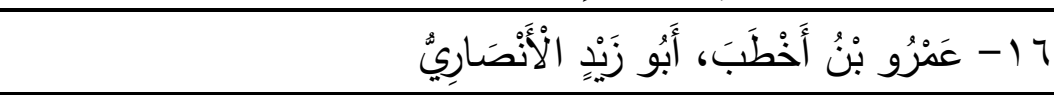 \\
\hline Vq & ا \\
\hline ^. & 11 ا- عَمْزُو بَنُ حُرَبَثٍ الُْقَرَشِيُّ \\
\hline Nr & 9 \\
\hline$\Lambda \varepsilon$ & •r. \\
\hline 10 & 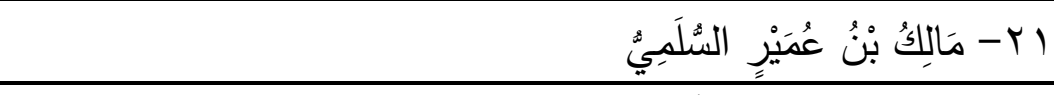 \\
\hline 14 & 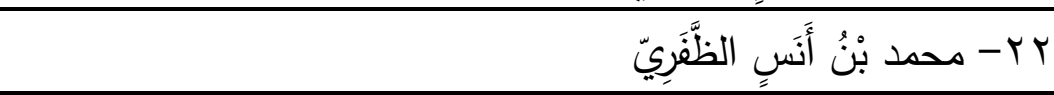 \\
\hline$\wedge \wedge$ & بr \\
\hline 9. & 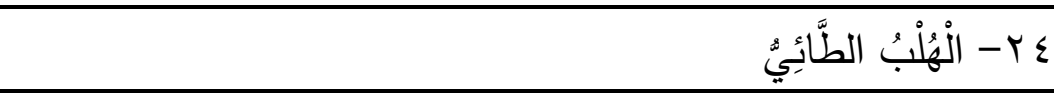 \\
\hline 9. & 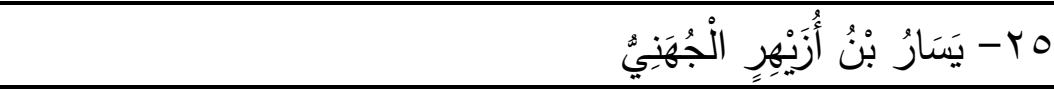 \\
\hline 91 & 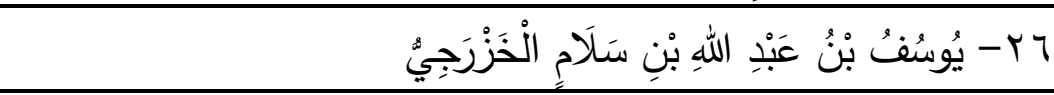 \\
\hline$a r$ & 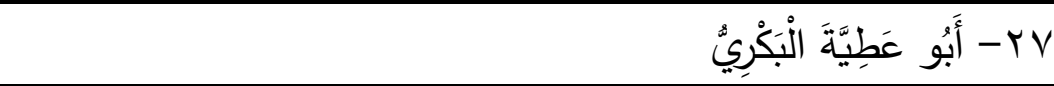 \\
\hline 94 & 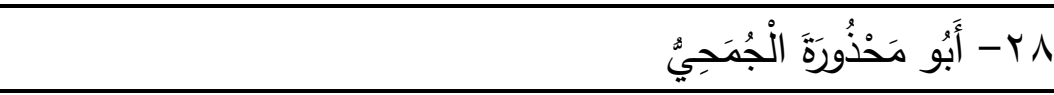 \\
\hline 90 & 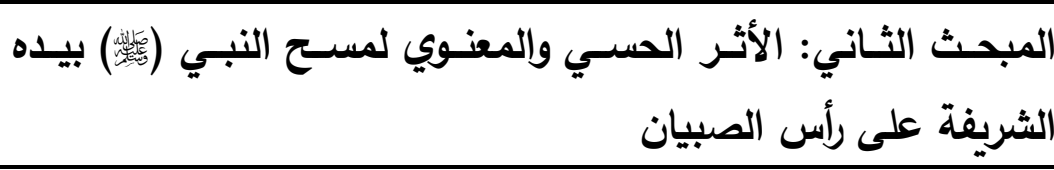 \\
\hline 90 & 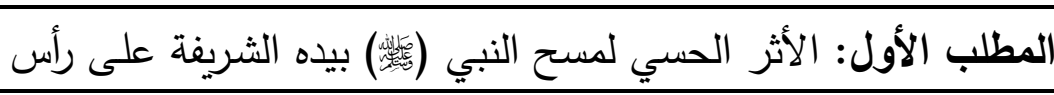 \\
\hline
\end{tabular}


مجلح كلية أصول الدين والدعوة بالمنوفية العدد التاسع والثثلاثوذ

\begin{tabular}{|c|c|}
\hline & الصبيان \\
\hline 99 & 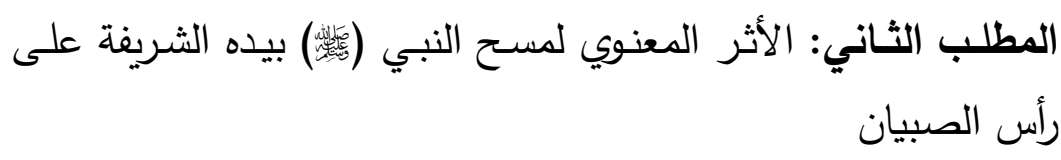 \\
\hline $1 . \varepsilon$ & الخاتمة \\
\hline $1 \cdot 7$ & فهرس المصادر والمراجع \\
\hline Ir. & فهرس المحتويات \\
\hline
\end{tabular}
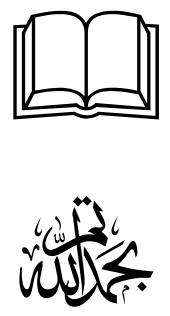